\title{
The Interplay between Circulating Tumor Cells and the Immune System: From Immune Escape to Cancer Immunotherapy
}

\author{
Kevin Leone, Cristina Poggiana and Rita Zamarchi * \\ Veneto Institute of Oncology IOV_IRCCS, Padua, Italy ; kevin.leone@iov.veneto.it (K.L.); \\ cristinapoggiana@gmail.com (C.P.) \\ * Correspondence: rita.zamarchi@unipd.it; Tel.: +39-049-821-1195
}

Received: 24 July 2018; Accepted: 28 August 2018; Published: 30 August 2018

\begin{abstract}
Circulating tumor cells (CTCs) have aroused increasing interest not only in mechanistic studies of metastasis, but also for translational applications, such as patient monitoring, treatment choice, and treatment change due to tumor resistance. In this review, we will assess the state of the art about the study of the interactions between CTCs and the immune system. We intend to analyze the impact that the cells of the immune system have in limiting or promoting the metastatic capability of CTCs. To this purpose, we will examine studies that correlate CTCs, immune cells, and patient prognosis, and we will also discuss relevant animal models that have contributed to the understanding of the mechanisms of immune-mediated metastasis. We will then consider some studies in which CTCs seem to play a promising role in monitoring cancer patients during immunotherapy regimens. We believe that, from an accurate and profound knowledge of the interactions between CTCs and the immune system, new immunotherapeutic strategies against cancer might emerge in the future.
\end{abstract}

Keywords: circulating tumor cells; immune system; immunotherapy; cancer biomarkers; liquid biopsy; metastasis

\section{Introduction}

In malignant evolution, cancer cells acquire the capability to invade healthy tissues and colonize distant organs. This process, indicated as metastatic cascade, includes an ordinate series of events involving tumor cells, namely their invasion into surrounding normal tissues, intravasation in the bloodstream, arrest, and extravasation through vascular walls into secondary sites, formation of microscopic colonies, and final proliferation into overt, clinically detectable metastases [1].

Although metastasis accounts for a remarkable $90 \%$ of cancer-associated deaths, it remains a poorly understood process because of the complex interplay that the primary tumor establishes with stromal cells, often based on redundant and still unclear signaling pathways [1]. Among stromal cells, those of the immune system especially affect the outcome of tumor progression and metastasis.

Furthermore, it is not yet clear when the metastatic capability of a tumor appears, because direct and indirect evidence have contrasted the view that the spreading of tumor cells to secondary sites represents a late event in tumorigenesis. For example, $30.6 \%$ of breast cancer (BC) patients at diagnosis show micrometastases in the bone marrow, independently of disease stage [2], and prostate cancer cells disseminate early [3]. Moreover, karyotypic abnormalities of micrometastases in the bone marrow from BC patients, as well as from animal models, indicate that tumor cell dissemination occurs in the pre-invasive stage of the disease [4]. Consequently, characterization of the primary tumor may not be enough to assess the risk for disease recurrence and to choose the best treatment, while by investigating metastases, which represent the final result of the process, we might lose relevant information about the characteristics necessary to overcome one or more steps of the metastatic cascade. 
On these bases, the study of circulating tumor cells (CTCs) has elicited increasing interest, especially after the advent of reliable technologies that permit isolation, quantification, and characterization of tumor cells after intravasation in the peripheral blood and before extravasation at secondary sites. Although this is only an intermediate step of the full metastatic process, it is a crucial step as demonstrated by the prognostic value of CTC numbers [5] and it is thought to contribute to the selection of phenotypic and biological properties that are necessary for tumor cells to complete the whole process [6]. Furthermore, since we can obtain tumor cells from a simple blood draw of a cancer patient as often as necessary, CTCs are considered of utmost importance not only in mechanistic studies of metastasis, but also for translational applications such as patient monitoring, treatment choice, and, in the case of ongoing resistance, treatment change.

For this reason, being aware of the novelty of immunotherapy of tumors in the precision medicine era, we thought to review what we know concerning the relationship between CTCs and the different cell populations of the immune system, with the aim to understand how the latter can prevent or even support the metastatic dissemination of the former.

Our review does not aim to debate different scenarios about the interactions between CTCs and the immune system, with the final goal of supporting one or the other, since the scientific knowledge on this topic is not yet complete. Rather, we feel the need to describe the state of the art regarding what we know on the role and mechanisms of the different immune cell populations in limiting or promoting the dissemination and persistence of CTCs.

To this purpose, in our literature searches, we used the keyword ' $\mathrm{CTC}$ ' (or the full form 'circulating tumor cell') in conjunction with 'macrophages', 'dendritic cells', and so on, according to the paragraph titles. For the keyword 'immunotherapy', we combined it with 'CTC' and, in some cases, with a third keyword, e.g., 'biomarkers', 'targets', and 'PD-L1'.

We reviewed not only studies performed in cancer patients that correlate CTCs, immune system cells, and prognosis, but also studies presenting relevant animal models that, by studying experimental tumors induced by cancer cell lines, or experimental metastasis induced by injection of cancer cell lines in the peripheral blood, which contributed to the understanding of immune-mediated mechanisms of metastasis. Based on our selection criteria, we used the acronym ' $\mathrm{CTC}$ ' only when talking about studies on human samples or on animal models in which CTCs were shed from primary tumors. In all other cases (in vitro assays and in vivo experimental metastasis), we talked about 'tumor cells' since in these conditions neoplastic cells were not actually circulating or part of a real metastatic process.

We then reviewed papers reporting results on immunotherapies, with particular regard to what we can directly monitor in cancer patients by studying CTCs.

Finally, we briefly looked at future opportunities, i.e., new immunotherapeutic strategies that we could implement using the knowledge on metastatic mechanisms gained from studies on CTCs.

\section{Immune-Surveillance and Immune-Support of CTCs}

The success rate of metastasis is low since only a few of the thousands of CTCs daily released in the bloodstream survive and form secondary lesions. For instance, in murine experimental metastasis models, Fidler found that only $1 \%$ of tumor cells survived in premetastatic lungs $24 \mathrm{~h}$ after intravenous injection [7], and Luzzi et al., at day 13 post-injection, observed that only $1 \%$ of liver micrometastases progressed to form macrometastases and that $36 \%$ of tumor cells remained isolated; $95 \%$ of which were dormant ( $2 \%$ proliferative and $3 \%$ apoptotic) [8]. Several reasons can explain this inefficiency, including the mechanical stress in blood vessels, the complexity of the translocation from one site to another, the presence of a final microenvironment unsuitable for proliferation, and the intervention of host immune surveillance [7-9].

In principle, we cannot exclude that the relationships between the immune system and tumor cells differ between primary tumor and peripheral blood. Indeed, in peripheral blood, CTCs migrate as single cells or tumor microemboli and undergo changes that are expected to modify their phenotype [10], so that CTCs might continue or interrupt their crosstalk with the immune system. 
Furthermore, after intravasation, CTCs lose all the interactions with both the extracellular matrix (ECM) and stromal cells; in this situation, cytokines and other soluble factors produced by immune system cells, which are usually only locally active, might no longer be effective on CTCs. In any case, it is conceivable (and generally accepted) that CTCs, leaving the protected microenvironment of the primary tumor, encounter further immune surveillance in nontumor tissues.

Immune cells ambiguously show both anti- and protumor effects. They can promote tumor progression and metastasis by creating an immunosuppressive, tolerogenic context or mediating ECM degradation and angiogenesis [11-13]. Tumor-derived soluble factors (TDSFs) mediate the recruitment of myeloid cells and hematopoietic progenitors in the target organ to adapt local microenvironment for CTC homing [14]. For example, tumor necrosis factor (TNF)- $\alpha$ supports survival and proliferation of tumor cells and increase vascular permeability $[15,16]$. Also, immunohistochemistry on biopsies from BC patients revealed that the chemokine receptor CXCR4 favors tumor cell homing in the bone marrow [17].

Interestingly, when Hensler and colleagues compared $\mathrm{BC}$ patients and healthy donors for gene expression profiles in both CTCs (obtained by immuno-magnetic sorting) and peripheral blood mononuclear cells (PBMCs), they found a higher expression of metastasis-related genes, such as those for ECM degradation and epithelial-mesenchymal transition (EMT), in patient PBMCs [18].

In the subsections below, we will consider the most important infiltrating and circulating immune cells that hinder or favor the dissemination of CTCs, in some cases directly interacting with them. The main mechanisms are depicted in Figure 1. 


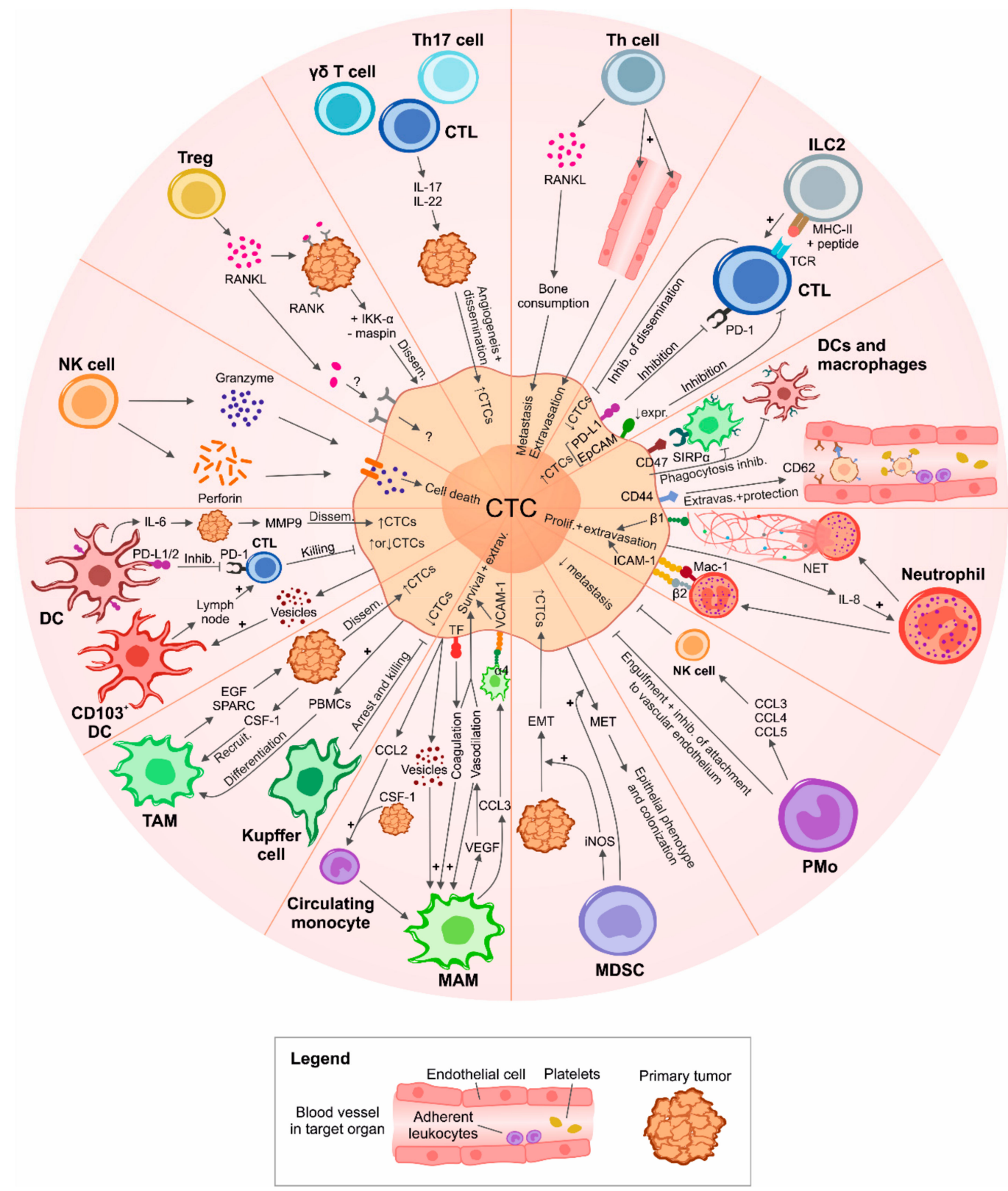

Figure 1. Representation of the main known mechanisms involving an interplay between CTCs and anti- or protumor cell populations of the immune system (+: induction).

\subsection{Natural Killer (NK) Cells}

The number of circulating NK cells has been observed to increase in metastatic breast, colorectal, and prostate cancer patients as compared to healthy donors [19]. NK cells can intercept CTCs in the bloodstream and destroy them before extravasation, thus preventing metastasis [20]. A study performed on mice injected with human colon cancer cells tried to elucidate the mechanisms used by NK cells to kill cancer cells. Direct perforin-dependent killing resulted more effective than indirect killing with apoptosis-inducing factors, since the former significantly delayed primary tumor growth, reduced the number of CTCs by $80 \%$ as assessed by real-time PCR, and hindered the formation of metastases, with respect to the latter [21].

Accordingly, low NK cell activity is associated with advanced disease and metastasis [22,23]. Metastatic BC patients with $>5$ CTCs per $7.5 \mathrm{~mL}$ of blood had circulating NK cells showing deficient lytic ability in chromium- 51 release assays as compared to those from patients with $\leq 5$ CTCs, and an 
inverse correlation between CTCs and progression-free survival (PFS) was found [24]. Also in metastatic breast, colorectal, and prostate cancer patients, the cytotoxic activity of NK cells inversely correlated with the level of CTCs detected by the CellSearch system (CS, Menarini-Silicon Biosystems, Castel Maggiore (BO), Italy) [19].

\section{2. $\mathrm{CD}^{+}$and $\mathrm{CD} 4^{+} \mathrm{T}$ Cells}

Our current knowledge concerning the function of $\mathrm{CD}^{+}$cytotoxic $\mathrm{T}$ lymphocytes (CTLs) and $\mathrm{CD}^{+} \mathrm{T}$ helper (Th) cells in immune surveillance of CTCs is very limited. Their infiltration in primary tumors, together with that of NK cells, correlates with an increase of disease-free survival (DFS) and overall survival (OS), and a reduction of metastasis and relapse [25,26]. Accordingly, in patients with metastatic BC, low circulating lymphocyte levels and high CTC levels, as assessed by CS, were found to be independent poor predictive factors for PFS and OS [27]. In inflammatory BC patients, the presence of CS-detected CTC s correlated with a reduction of CD3 ${ }^{+} \mathrm{T}$ cells, CD4 ${ }^{+} \mathrm{T}$ cells, and $\mathrm{CD}^{+} \mathrm{T}$ cells synthesizing TNF- $\alpha$ and IFN- $\gamma$ [28]. In stage IV non-small-cell lung cancer (NSCLC) patients, Ye et al. showed that the number of CTCs as determined by SET-iFISH correlated negatively with that of $\mathrm{NK}$ cells and $\mathrm{CD}^{+}, \mathrm{CD}^{+}$, and $\mathrm{CD}^{+} / \mathrm{CD}^{+}$lymphocytes, while positively with metastasis [29]. Another study performed on late stage NSCLC patients gave comparable results, since CTCs showing both epithelial and mesenchymal markers in RNA-ISH assays negatively correlated with $\mathrm{CD}^{+}$and $\mathrm{CD}^{+} \mathrm{T}$ cells; moreover, CTC levels positively correlated with metastasis and a worse clinical outcome [30].

In a different study, BC patients positive for CTCs after AdnaTest were characterized by a significant increase of peripheral first apoptosis signal receptor (FAS)-positive Th cells [31]. The induction of apoptosis in T cells could represent an escape mechanism used by CTCs (see Section 3) and potentially explain the observed CTC-related lymphocytopenia. However, it is not clear if CTCs control the number of lymphocytes or if the increase in CTCs is the consequence of a lymphocyte dysfunction due to other factors, in particular, immunosuppression exerted by the primary tumor.

\subsection{Regulatory T Lymphocytes (Tregs)}

By releasing TDSFs, such as interleukin (IL)-10, transforming growth factor (TGF)- $\beta$, and galectin 1 , the tumor can stimulate the generation and expansion of Tregs, which can impair antitumoral immune responses, subsequently allowing disease progression and metastasis [32,33]. Indeed, in metastatic melanoma patients, an increased frequency of Tregs correlated with disease progression [34], while in node-negative BC patients, it correlated with both disease progression and lymph node micrometastases [35]. Several studies on different murine tumor models closely associated Tregs with the establishment of metastases [33,36-39].

Accordingly, in metastatic carcinoma patients, circulating Tregs were more abundant as compared to healthy donors, although the numbers of Tregs did not correlate with CTCs; probably due to the low-sensitivity test (immunocytochemistry) used to identify CTCs, as concluded by the authors themselves [40]. Conversely, in inflammatory BC patients, CS-enumerated CTCs positively correlated with circulating Tregs [28]. In the already-mentioned work by Ye et al. performed on advanced NSCLC patients, high numbers of CTCs correlated, not only with lymphocytopenia and metastasis, but also with high numbers of Tregs [29]. In addition, in a study performed with PCR and FACS, high pre-resection levels of both epithelial cell adhesion molecule (EpCAM)-positive CTCs and circulating Tregs correlated with a higher risk of post-resection recurrence and metastasis in hepatocellular carcinoma patients [41]. Thus, the combination of CTCs and circulating Tregs might provide a novel prognostic predictor of cancer progression.

Interestingly, in a transplantable BC mouse model, Tregs infiltrating the primary tumor were found to produce receptor activator of nuclear factor kappa-B ligand (RANKL), a tumor-necrosis-factor family member involved in bone regeneration and remodeling, as well as in mammary gland hyperplasia during pregnancy. Released RANKL stimulated lung metastatic dissemination of RANK $^{+}$tumor cells 
through activation of IKK- $\alpha$ and downregulation of the metastasis inhibitor maspin [42]. Noteworthy, RANK has been detected on CTCs from melanoma patients [43].

\subsection{Other Lymphocytic Subsets}

In an invasive BC model, the tumor-released chemokine CCL2 and the subsequent IL-1 $\beta$ release from TAMs (see Section 2.8) were shown to induce IL-17 production in $\gamma \delta \mathrm{T}$ cells. In turn, IL-17 caused a systemic granulocyte colony-stimulating factor (G-CSF)-dependent expansion of neutrophils, that suppressed CTLs and led to increased metastasis [44,45]. CD4 ${ }^{+} \mathrm{T}$ helper 17 (Th17) cells also produce IL-17 and have been associated with MDSC-mediated immunosuppression (see Section 2.7) and metastasis [46]. Accordingly, in a study on a transplantable murine colorectal cancer (CRC) model, the authors found corresponding changes between serum IL-17A levels and the FACS-determined prevalence of CTCs at different stages of disease; moreover, IL-17A promoted angiogenesis and metastasis in vivo, as well as matrix metalloproteinase 9 (MMP9)-dependent invasiveness of tumor cells in vitro [47]. Mego et al. also showed a correlation between CS-derived CTC counts and the percentage of activated IL-17-producing $\mathrm{CD}^{+} \mathrm{T}$ cells [28]. Other papers proved that systemic IL-17, through activation of the IL-6/Stat3 pathway and release of MMP2/9, TNF- $\alpha$, and vascular endothelial factor (VEGF), induces tumor cell migration and metastatic growth in lung cancer-bearing mice [48-50]. IL-22 is another cytokine produced by $\gamma \delta$ and Th17 cells that induces Stat 3 and MMP9 in cancer cells to increase their motility and, in human pancreatic ductal adenocarcinoma, their metastatic capability [51].

Mammary tumor antigen-activated $\mathrm{CD}^{+} \mathrm{T}$ cells can prepare the bone premetastatic niche by releasing RANKL and inducing osteolytic bone disease, with subsequent consumption and metastatic colonization of the bone cavity [52]. In another study, allergen-induced pulmonary inflammation was linked to a higher risk of lung experimental metastasis due to a $\mathrm{CD}^{+} \mathrm{T}$ cell-mediated activation of the vascular endothelium, which, in microfluidic in vitro assays, was required for an enhanced transendothelial migration of cancer cells [53].

In a recent study on spontaneous and transplantable tumor-bearing mice, the tumor-evoked regulatory B cells (tBregs), a lymphocyte subpopulation that derives from TDSF-conditioned B cells, induced the differentiation of $\mathrm{CD} 4^{+} \mathrm{T}$ cells into Tregs and fully activated the prometastatic functions of cancer-primed MDSCs through the TGF- $\beta$ signaling, eventually increasing metastasis [36,54].

Finally, type 2 innate lymphoid cells (ILC2s) are gaining increasing interest as they can activate myeloid cells by secreting cytokines and directly induce T cells by expressing MHCII molecules [55]. ILC2s participate in immune surveillance against CTCs, since in transplantable murine models they are recruited to the primary tumor in an IL-33-reliant manner and mediate CTL activation together with DCs, hence producing a decrease in tumor growth, CTCs (evaluated by FACS), and metastasis [56].

\subsection{Neutrophils}

The primary tumor can secrete G-CSF, which induces granulopoiesis in the bone marrow and recruits neutrophils-cells actively involved in tumor progression and metastasis $[57,58]$. In spontaneous and transplantable BC mouse models, neutrophils were shown to accumulate in premetastatic lungs and produce $\mathrm{H}_{2} \mathrm{O}_{2}$, with subsequent killing of incoming CTCs (as demonstrated by histology) and inhibition of metastasis; the authors also stated (without presenting relative data) that the number of CTCs was not affected by neutrophils [59]. Nonetheless, the surveillance exerted by neutrophils over CTCs is so far largely unexplored.

Conversely, more data are available on neutrophil support to CTCs. As already discussed, systemically raised G-CSF upon $\gamma \delta \mathrm{T}$ cell activation polarizes neutrophils towards an immunosuppressive behavior that favors metastatic progression [44,45]. Moreover, G-CSF also induces homing of $\mathrm{Ly}_{6 \mathrm{G}}{ }^{+} \mathrm{Ly}_{6 \mathrm{C}} \mathrm{C}^{+}$granulocytes in the premetastatic lungs of tumor-bearing mice, where they can release the Bv8 protein that induces angiogenesis, further mobilization of myeloid and tumor cells, and final metastasis [58]. 
Neutrophils have been extensively associated to tumor angiogenesis and, thus, to an easier dissemination of tumor cells [60]. For example, UV irradiation-induced metastasis of primary melanoma was shown to be mediated by activated neutrophils that prompt angiogenesis and TNF-dependent migration of melanoma cells towards vascular endothelial cells, both in vitro and in vivo [61].

Several in vivo imaging studies showed that CTCs colocalize with endothelium-bound neutrophils in the premetastatic vascular network, suggesting that neutrophils can retain cancer cells and facilitate their extravasation. For example, adherent neutrophils within the inflamed liver sinusoids interact with intravenously-injected lung cancer cells and increase their tethering ability to CD62 (selectin) on the vascular endothelium [62,63]. In vitro assays and in vivo experimental metastasis demonstrated that melanoma cells entrapped in premetastatic lung capillaries release IL-8 and recruit neutrophils that, in turn, upregulate $\beta 2$ integrins and bind intercellular adhesion molecule (ICAM)- 1 on tumor cells, favoring their anchoring to blood vessels [64]. Activated neutrophils also adhere to CTC s through interaction of Mac-1 on the former and ICAM-1 on the latter [63]. ICAM-1 is then able to trigger migration-related signaling pathways inside tumor cells, thus promoting extravasation and colonization of adjacent tissues [65].

Furthermore, once stimulated by G-CSF, IL-8, or other pro-inflammatory factors, neutrophils undergo a process called NETosis and release neutrophil extracellular traps (NETs), i.e., networks of DNA and antimicrobial proteins, which, in physiological conditions, catch and contain pathogens. During systemic inflammation in mice, NETs capture systemically-delivered cancer cells and improve their adherence to liver blood vessels, extravasation, and metastatic spreading [66]. NET-released high mobility group box 1 (HMGB1) augments cancer cell adhesion, proliferation, and migratory capabilities in vitro in a toll-like receptor 9 (TLR9)-dependent manner [67]. Remarkably, in a transplantable tumor model, CTCs themselves induced the formation of metastasis-supporting NETs in the absence of infection [68], and this could depend on neutrophil priming upon tumor release of G-CSF [69]. In a recent study performed on a murine intra-abdominal sepsis model that mimics postoperative inflammation, Najmeh and colleagues showed the central role of $\beta 1$ integrin in mediating the interaction between CTCs and NETs [70].

In metastatic CRC patients who had undergone liver resection, postsurgical inflammation caused an increase in NETs, which correlated with a $>4$-fold metastasis-dependent reduction in DFS [67]. NETs have also been observed in patients with pancreatic ductal adenocarcinoma [71] and BC [68], while in gastric cancer patients the number of NETs resulted higher than in healthy donors and increased with disease progression [72]. However, to date, no findings are available for NETs and CTCs in human cancer.

\subsection{Monocytes}

Circulating monocytes comprise two subpopulations, classical and nonclassical monocytes. As we will discuss later, classical 'inflammatory' monocytes can extravasate and differentiate into macrophages with protumor and prometastatic functions. Conversely, in response to the CX3CL1 chemokine, nonclassical 'patrolling' monocytes (PMos) accumulate in capillaries, where they clear circulating cellular debris, and intervene in inflammation with a protective role [73]. Hanna et al. showed in different murine metastatic tumor models that, up to $24 \mathrm{~h}$ after intravenous cancer cell injection, PMos are recruited to premetastatic lung capillaries through the CX3CL1/CX3CR1 axis and engulf tumor material, while as early as $4 \mathrm{~h}$ after injection they interact with tumor cells in circulation and hamper their attachment to the lung microvasculature. Moreover, the PMo-secreted CCL3, CCL4, and CCL5 chemokines summon and activate NK cells, thus leading to further elimination of metastasizing tumor cells and prevention of lung metastasis [74].

Finally, the expression of TLR2 and TLR4 on whole, peripheral monocytes was found to inversely correlate with the level of CS-detected CTCs in metastatic breast, colorectal, and prostate cancer patients [19]. 


\subsection{Myeloid-Derived Suppressor Cells (MDSCs)}

MDSCs are heterogeneous, immature myeloid cells comprising a polymorphonuclear subset (PMN-MDSCs) and a monocytic subset (M-MDSCs), which can be respectively distinguished from granulocytes and monocytes due to their high immunosuppressive activity [75]. Infiltrating and circulating MDSCs can favor metastasis by creating a tolerogenic microenvironment in both the primary tumor and metastatic sites [54,76-78]. Interestingly, in a study on portal vein blood samples from pancreatic cancer patients, the authors found a correlation between numbers of circulating M-MDSCs and active FACS-isolated K-RASmut ${ }^{\mathrm{mRNA}+}$ CTCs, suggesting that the establishment of liver metastases in these subjects may be supported by immunosuppression-dependent CTC survival in the bloodstream [79].

Furthermore, MDSCs can directly stimulate aggressiveness of tumor cells. By releasing IL-6, MDSCs elicit STAT3 activation and invasive capabilities of BC cells, with subsequent increase in tumor and metastasis burden [80]. MDSCs can also facilitate neoplastic cell dissemination by releasing MMP9 and degrading the ECM [81], as well as by upregulating MMP2, MMP13, and MMP14 in BC cells [82]. MMP9 from PMN-MDSCs has also been implicated in the generation of an aberrant and leaky vasculature in the premetastatic lung [83]. Additionally, PMN-MDSCs can promote EMT in melanoma cells through activation of the TGF- $\beta$, epidermal growth factor (EGF) or hepatocyte growth factor (HGF) signaling pathways, leading to enhanced metastasis [84]. Ouzounova et al. recently showed in a transplantable murine BC model that tumor-infiltrated M-MDSCs promote inducible nitric oxide synthase (iNOS)-mediated EMT and cancer stem cell properties in tumor cells at the invasion frontline; then, PMN-MDSCs in metastatic lungs induce mesenchymal-epithelial transition (MET) in CTCs and restore their original phenotype to foster settlement and proliferation [85]. Thus, MDSCs seem to be involved in EMT, although the role of their two subsets needs to be clarified.

\subsection{Macrophages}

Kupffer cells are liver resident macrophages able to detect and arrest CTCs while passing in the bloodstream and remove metastasizing tumor cells from the hepatic parenchyma [86]. Indeed, CTC counts obtained by CS and Epispot in paired peripheral and mesenteric blood samples from CRC patients suggested that the liver entraps a fraction of CTCs [87]. Kupffer cells may act both by activating adjacent $\mathrm{T}$ cells against CTCs and by recognizing opsonized tumor cells and directly killing them $[86,88]$.

Beyond tissue-resident macrophages, those derived from circulating monocytes and M-MDSCs can actively participate in cancer, since tumor-associated macrophages (TAMs) infiltrate advanced tumors $[89,90]$ and their detection correlates with a poor prognosis [91-93]. TAMs can directly prompt the migration of tumor cells by secreting paracrine factors. As shown by Wyckoff et al., one of these factors is EGF, which also activates tumor cells to release colony-stimulating factor (CSF-1), thus promoting the motility of TAMs themselves [94]. Loop mechanisms like this explain why TAMs and tumor cells often move together in tumor stroma toward blood vessels [94,95]. Accordingly, the inhibition of CSF-1 or EGF signaling in tumor-bearing mice undergoing intravital imaging experiments reduced metastasis by decreasing the number of macrophages and tumor cells able to leave the primary tumor [94]. Another example is represented by TAM-released secreted protein acidic and rich in cysteine (SPARC), which results to be necessary for metastasis, since it favors migration of cancer cells by aiding their integrin-mediated interaction with nearby stroma [96].

TAMs have also been shown to promote tumor cell invasion through release of other factors, namely:

1. Oncogenic miR-22-containing exosomes, able to trigger the Mef2c- $\beta$-catenin pathway [97];

2. the chemokine CCL18, which induces calcium signaling and integrin clustering [98];

3. the chemokine CCL20 recognized by the CCR6 receptor [99].

Furthermore, TAMs can facilitate cancer cell migration by activating EMT, for example upon release of lipocalin-2 (LCN2) [100], TNF- $\alpha$ [101], IL-8 [102,103], IL-6 [104], and TGF- $\beta 1$ [105,106], which operate via activation of different EMT-promoting molecular pathways (e.g., Gas6/Axl-NF-kB, 
JAK2/STAT3/Snail, and PI3K/Akt). When experimental blocking of these pathways was performed, a reduction in the number of metastases was observed, suggesting the importance of TAMs in tumor cell dissemination and disease progression.

Motility of cancer cells can also be enhanced upon physical interaction with TAMs, which induce both RhoA activity and Notch1 signaling in tumor cells. In turn, Notch1 regulates Mena ${ }^{\mathrm{INV}}$ expression, which is required for the formation of invadopodia, matrix degrading protrusions used by cancer cells for invasion, and transendothelial migration $[107,108]$. Consistently, when mice with BC xenografts were treated with a Notch1-blocking antibody, CTCs (counted as plated, colony-forming cells from blood) diminished when compared to the control group [108].

Another study investigated the interplay between macrophages and CTCs. Hamilton and coworkers first established two permanent CTC lines from blood samples of advanced stage small cell lung cancer patients and, then, cultured in CTC-conditioned media healthy donor-derived PBMCs, which afterwards differentiated into monocytes/macrophages expressing the TAM markers CD14, CD163, and CD68. In addition, macrophage supernatants contained several soluble factors linked to tumor cell invasiveness, angiogenesis, and immune protection, thus suggesting that CTCs might educate TAMs to support their dissemination in vivo [109].

TAMs are not the only macrophages with a metastasis-promoting activity. Circulating monocytes and myeloid progenitors can be chemoattracted by CTC-derived CCL2 into blood vessels of the metastatic organ and, then, can anchor to the endothelium and transmigrate [110]. Once extravasated, these cells can bind CSF-1 released by cancer cells and differentiate into metastasis-associated macrophages (MAMs) [11,111,112].

MAMs and other infiltrating myeloid cells can promote vasodilatation in the premetastatic niche by directly secreting VEGF or mediating protease-dependent release of ECM-bound VEGF. Thus, the more abundant blood flow allows further accumulation of MAMs and CTCs [110,112,113]. Another synergistic mechanism of metastatic seeding is based on the tissue factor (TF) expressed on systemically-injected cancer cells, which can recruit platelets and activate coagulation in blood vessels near the target organ; this allows the arrest of other cancer cells and monocytes/macrophages in circulation [114]. Many other recruitment mechanisms are still not fully elucidated, such as that recently reported after intravital imaging in mice by Headley et al. Here, the authors showed that metastasis-promoting CTC-shed $5 \mu \mathrm{m}$ microparticles and were able to enter neutrophils, monocytes, and macrophages in metastatic lungs within $24 \mathrm{~h}$ after arrival of CTCs [115].

In the context of the premetastatic niche, MAMs acquire metastasis-promoting functions. Once activated by CCL2, MAMs produce the autocrine chemokine CCL3, which enhances the interaction between vascular cell adhesion molecule-1 (VCAM-1) on tumor cells and the $\alpha 4$ integrin on MAMs, resulting in a reciprocal, efficient retention and extravasation of macrophages and CTCs at the metastatic site, as demonstrated in various spontaneous and transplantable murine cancer models [116]. In addition, through both VEGF-mediated vasodilatation and physical interaction, MAMs support extravasation, survival, and proliferation of CTCs. Indeed, the elimination of MAMs in metastasis-bearing mice reduces the number of extravasating cells (as determined by real-time PCR) and further metastatic growth [112]. A possible explanation of this survival advantage for cancer cells was proposed by Chen et al., who showed that the binding between $\alpha 4$ integrins on MAMs and VCAM-1 on tumor cells can trigger the Ezrin-PI3K/Akt anti-apoptotic pathway in the latter [117].

Like TAMs in the primary tumor, MAMs in metastatic sites also produce proteases to aid tumor cell invasion, such as cathepsin S, which has been shown to degrade the JAM-B junctional adhesion molecule in the blood-brain barrier and enhance breast-brain metastasis in both murine models and patients [118].

\subsection{Dendritic Cells (DCs)}

DCs comprise the conventional (myeloid) and plasmacytoid (lymphoid) subsets [119]. In both cases, mature DCs are considered to be immunostimulatory and, accordingly, mature DCs that infiltrate the tumor have been associated with a better patient outcome in terms of tumor progression and 
metastasis [120-122]. In BC patients positive for CTCs according to CS, circulating DCs showed increased expression of TLR2, TLR4, and TLR8 and a decreased expression of TLR3 as compared to negative patients. However, it is not clear if this represents an effort of the immune system to respond to tumor-derived ligands or if it is associated to an immune dysfunction potentially having protumor effects [123]. Nonetheless, intravital imaging on metastatic lungs in mice injected with cancer cells showed that resident $\mathrm{CD}_{103^{+}} \mathrm{DCs}-$ a subset able to cross-present antigens directly to CTLs-can internalize CTC-derived microparticles and migrate to lymph nodes, where they enhance antitumor CTL responses and restrain the metastatic burden [115].

Tumor-infiltrating DCs often do not efficiently stimulate immune responses, since TDSFs can cause accumulation of immature DCs and decreased production of mature DCs inside the tumor, impairing their APC functions [120,124]. Mego et al. recently related the phenotype of circulating conventional and plasmacytoid DCs to both CS CTC counts and clinical outcome in inflammatory BC patients. The authors demonstrated that patients with $\geq 5 \mathrm{CTCs}$, as compared to patients with $<5 \mathrm{CTCs}$, had a significantly more advanced disease stage, a worse OS, a reduced percentage of conventional DCs producing TNF- $\alpha$, IFN- $\alpha$, and IL-12 and a higher expression of CCR7 and CD86 on conventional and plasmacytoid DCs, respectively. These observations suggest that patients with $\geq 5$ CTCs had defects in DC number and function, despite an enhanced activation and maturation, and a potentially compromised Th1-like immune response [125].

Both DC subsets have also been directly linked to metastasis. CCL2 and LCN2 from tumor cells induce EMT and generation of regulatory dendritic cells (DCregs), DCs that show an immunosuppressive behavior, low expression of the stimulatory molecules HLA-DR, and CD86, and high expression of the immunosuppressive molecule programmed death-ligand 1 (PD-L1). In turn, DCregs activate Tregs and inhibit tumor-specific CTLs, finally enhancing tumor growth and metastasis [126].

Another immunosuppressive DC subpopulation has been newly described in a murine pancreatic ductal adenocarcinoma model, where, in response to tumor GM-CSF, monocyte-derived CD11 $\mathrm{b}^{+}$ $\mathrm{CD}_{11} \mathrm{c}^{+} \mathrm{MHCII}^{+} \mathrm{CD} 24^{+} \mathrm{CD} 64^{\text {low }} \mathrm{F} 4 / 80^{\text {low }}$ DCs infiltrated the premetastatic liver. These cells activated Tregs, inhibited CTLs and reduced metastasis through a mechanism involving the MGL2 lectin and PD-L2 [127]. Interestingly, besides impairing DC maturation as mentioned above, tumor-derived exosomes are also able to activate DC prometastatic activity. Indeed, exosomes expressing HSP72 and HSP105 can trigger a TLR2- and TLR4-dependent IL-6 release from conventional DCs and a consequent MMP9 expression in tumor cells with enhanced invasion and metastasis [128]. Furthermore, the number of $\mathrm{CD} 83^{+}$mature DCs in the primary tumor of CRC patients correlated with the presence of tumor cells in blood and lymph vessels as assessed by histology, and local lymph node metastases [129].

Likewise, the involvement of plasmacytoid DCs in metastasis has been investigated, although to date few references are available. This subset expands in bone lesions derived from BC and leads to a Th2-like response, as well as to an accumulation of Tregs and MDSCs. Subsequent immunosuppression and release of osteolytic cytokines elicit bone destruction, thus enhancing tumor growth and metastasis [130]. An accumulation of plasmacytoid DCs has also been observed in metastasis from other malignancies, such as BC [131] and melanoma [132]. Moreover, in the peripheral blood from gastric cancer patients, the number of these cells increased in the case of advanced disease and presence of lymph node metastasis [133].

\subsection{Other Circulating Immune Cells Interacting with CTCs}

CTCs can be found as single cells or clusters, named 'circulating tumor microemboli' (CTMs), that also comprise leukocytes, endothelial cells, fibroblasts, and other cells held together by cell adhesion proteins [134-136]. CTCs inside CTMs are protected from both immune recognition and therapeutics; this 'stealthiness' represents a tumor escape mechanism, which can also be provided by platelets alone (see Section 3). In this regard, Jiang at al. recently proposed a microfluidic method to isolate platelet-coated CTCs and CTMs that was not based on the detection of CTC surface 
epitopes, in this way overcoming the problems associated with masking by platelets and other cells. An intriguing hypothesis suggested by the authors is that platelets may enable CTC-immune cell interactions inside CTMs [137].

A particular a CD14 $4^{+} \mathrm{CD} 11 \mathrm{c}^{+} \mathrm{CD} 45^{+}$myeloid subpopulation has been observed inside CTMs. Adams and colleagues named these cells 'cancer-associated macrophage-like cells' (CAMLs) and described them as giant cells (30-300 $\mu \mathrm{m}$ in length) with large multiple or polylobated nuclei (14-64 $\mu \mathrm{m}$ in diameter) [138]. The expression of CD14 and CD45 ranges from intense to absent, and the morphology of these cells is very variable, since it can be amorphous, round, oblong, tadpole-, or spindle-shaped. This phenotypic variability, similar to the plasticity of macrophages, suggests that CAMLs may also have different stages of maturation and differentiation [138]. CAMLs have been detected in the peripheral blood of patients with breast, prostate, pancreas and lung cancer in percentages ranging from 81 to $97 \%$ of total patients, whilst totally absent in healthy individuals $[138,139]$.

Interestingly, CAMLs can be EpCAM-positive and/or CK8/18/19-positive, although it is still unclear if they directly express these epithelial markers (at different levels depending on the differentiation stage) or if they engulf material of epithelial origin. A possible explanation is that CAMLs internalize tumor cells/CTCs or their debris, as suggested by the presence of tumor-specific markers and mutations inside CAMLs [138]. Accordingly, other researchers working on macrophage-tumor cell fusions (MTFs) could cultivate resulting fused cells present in the blood from melanoma patients and observe primary tumor-specific mutations [140]. The internalization/fusion hypothesis is supported by the fact that CAMLs seem to originate in the primary tumor and increase in blood samples from patients responding to radiotherapy, chemotherapy, or other treatments, generally when dead tumor cells and debris accumulate [138,141]. CAMLs have also been shown to actively interact with CTCs or express CD146 and TIE2, markers that can suggest a pro-angiogenic activity [138]. In support of a protumor role of these cells, in metastatic BC patients, EpCAM ${ }^{+}$CAMLs correlate with shorter OS and PFS [142].

Therefore, both the origin and function of CAMLs in the tumor context are still under investigation, but they appear to be interesting liquid biopsy-based predictors of tumor activity and response to therapy. It cannot be excluded that CAMLs might also have an active role in helping CTC intravasation, extravasation, or survival in the bloodstream, thus participating in the metastatic process.

\section{CTC Evasion from Immune Surveillance}

Since the early phases of tumor progression, a delicate equilibrium arises between the antitumoral immunity and tumor escape mechanisms. The selection of less immunogenic tumor cell clones (cancer immunoediting) and the promotion of an immunosuppressive microenvironment able to limit immune responses and favor neoplastic progression are paramount in this process [12].

Several mechanisms have been hypothesized through which CTCs could escape or survive from encounters with immune cells [143]. Some mechanisms involve modifications in MHCI molecules:

1. The downregulation or loss of surface MHCI expression to escape the action of CTLs (an event that, in fact, makes them susceptible to the action of NK cells) [144];

2. the acquisition of a 'pseudonormal' phenotype by the transfer of MHCI molecules from the surface of platelets to escape NK cell-mediated cytotoxicity [145];

3. the expression of cytokeratins (CK8, CK18, CK19) that interfere with the recognition of MHCI complexes by $\mathrm{T}$ cell receptors (TCRs) on CTLs [146].

Other mechanisms not involving MHCI modifications are:

1. The expression of PD-L1, which prevents T cell-mediated destruction [147-150];

2. the expression of CD47, which provides a 'don not eat me' signal [151-153];

3. an altered expression of the apoptotic FAS and/or FASL proteins that may induce the apoptosis of T cells [31] or protect tumor cells from FAS-mediated apoptosis [154]; 
4. the association of CTCs inside CTMs, where they are hidden and protected from immune attacks [155];

5. the interaction with platelets, which induce EMT-like features in CTCs [156], promote their arrest and extravasation [157], and, as already mentioned, form a coating shield that provides them with 'stealth' properties and helps their survival in the circulation [158].

\subsection{CTC Surface Markers Involved in Immune Escape and Metastatic Dissemination}

Several CTC surface markers, potentially involved in CTC escape from the immune system, could represent therapeutic targets to prevent metastasis.

\subsubsection{CD44}

CD44 is a ubiquitous multistructural and multifunctional cell surface glycoprotein. It participates in a wide variety of cellular functions including cellular adhesion, hyaluronate degradation, lymphocyte activation, lymph node homing, myelopoiesis, lymphopoiesis, angiogenesis, and cytokine release. CD44 is overexpressed in several tumors [159]. The binding of CD44 on migrating tumor cells to CD62 on endothelial cells is responsible for the initial steps of extravasation. Moreover, CD62 is also expressed on platelets and its binding to CD44 creates a coat that protects tumor cells from cytotoxic effector cells in in vivo models [160]. Alternative splicing determines structural and functional diversity of this protein and may be related to tumor metastasis [161].

CTCs from patients with metastatic BC, capable of metastasizing in immunocompromised mice, express CD44 [152]. Katoh et al. collected CTCs from 150 patients affected by sporadic CRC and examined the relationship between expression of the CD44v9 mRNA and prognosis through reverse transcription PCR. They showed that the survival rate was significantly lower in stage III and unresectable stage IV CRC patients with CTCs positive for CD44v9 mRNA expression and speculated that CD44v9 mRNA in CTCs could be a useful marker to predict recurrence, prognosis, and treatment efficacy in CRC patients [162].

\subsubsection{CD47}

CD47 is a cell surface ubiquitous glycoprotein, belonging to the immunoglobulin (Ig) superfamily. Upon binding to its ligand signal-regulatory protein $\alpha$ (SIRP $\alpha$ ), expressed on macrophages and DCs, CD47 inhibits phagocytosis by these cell types [163]. For this reason, CD47 is known as a 'don't eat me signal' [164] and its upregulation on CTCs might confer a nonimmunogenic profile, enabling them to escape from phagocytosis. An overexpression of the CD47 gene was found in CTCs from CRC patients as compared to corresponding primary tumor tissue, suggesting a potential survival advantage [153]. CD47 was also expressed in CD44 ${ }^{+}$CTCs from a progressive metastatic BC patient. The same patient had a primary tumor negative for $\mathrm{CD} 47$ but developed a bone metastasis with a high expression of CD47 after seven years; this suggests that CD47 expression was probably acquired during the initiation of metastatic dissemination [152].

\subsubsection{PD-L1}

PD-1 is a member of the B7/CD28 family of co-stimulatory receptors. It regulates T cell activation through binding to its ligands, PD-L1 and PD-L2, both of which are expressed on many other cell types. When PD-L1 binds to PD-1, a strong inhibitory signal is transmitted into the T cell, leading to a reduction of cytokine production and suppression of $\mathrm{T}$ cell proliferation. Under physiological conditions, the PD-1/PD-L1 (or PD-1/PD-L2) interaction is necessary to mediate the natural immune tolerance [165]. In some tumors this protective mechanism is led to perversion through the overexpression of PD-L1 with the consequent prevention of an immune response against cancer [166]. The expression of PD-L1 has been demonstrated on CTCs of several malignancies [147-150,167-172] and associated with a poor prognosis $[148,149,167,170]$. 


\subsubsection{EpCAM}

EpCAM is a cell surface glycoprotein that has gained considerable interest in the diagnosis and treatment of cancer because it is frequently overexpressed in epithelial tumors [173]. To date, EpCAM is the antigen of choice for CTC enrichment from patient blood samples and this principle is at the basis of the CS system, the only clinically-validated, FDA-cleared system for identification, isolation, and enumeration of CTCs from blood samples.

Although the available technologies are mostly EpCAM-dependent, the detractors of the use of this protein complain that a fraction of CTCs cannot be quantified yet through the CS (more aggressive, undifferentiated, or EMT cells?). The limits of current technologies for isolation of CTCs represent a hot topic, but their discussion is beyond the scope of our review. Other authors in this special issue, as well as ourselves elsewhere, have already extensively addressed these arguments [174]. For our purpose, it is enough to remember herein that, before arriving to patient's bedside, a tumor marker must demonstrate its analytical and clinical validity and, finally, its clinical utility. The quality of available data determines the level of evidence, the strongest being Level 1, i.e., the definitive demonstration of clinical utility that can be obtained through a single, high-powered, prospective, randomized, controlled trial or from a meta-analysis or overview of multiple, well-designed studies. The European Pooled Analysis Consortium (EPAC) demonstrated the clinical validity of the CS assay, with Level 1 evidence in 2014 [5].

We should also remember that the meaning of any malignant feature of CTCs should be judged according to the degree of clinical validation of a certain phenotypical/molecular characteristic that we are using to identify CTCs in peripheral blood [175]. For this reason, after looking for potential targets in immunotherapy and their association with patient survival, we found and reported here, for the most, studies exploiting EpCAM-based technologies.

EpCAM overexpression has been associated with both decreased and increased survival of patients [176]. Dynamic changes in EpCAM expression frequently occur during tumor progression and its downregulation was observed during EMT [177]. Evidence suggests that epithelial plasticity could also be implicated in tumor immune escape [178]. In particular, the acquisition of an EMT phenotype has been associated with an inhibition of CTL-mediated tumor cell lysis in the human MCF-7 cell line [179]. Since EMT CTCs have also been correlated with disease progression and chemotherapy resistance $[10,180]$; enrichment systems that allow simultaneous investigation of both EpCAM ${ }^{+}$and $\mathrm{EpCAM}^{-} \mathrm{CTC}$ are being employed in order to obtain more complete information about the role of EpCAM in tumor progression [181].

\section{CTCs as Biomarkers in Cancer Immunotherapy}

The progress achieved in recent years in understanding the molecular mechanisms underlying cancer has allowed the development of targeted therapies, with the hope to select the most appropriate treatment for individual patients. Among these strategies, immunotherapy has brought enormous progress to cancer treatment.

The main goal of cancer immunotherapy is to reinforce the patient's suppressed immune system, ideally restoring its capability to eradicate cancer. The mechanisms of tumor escape from immune surveillance represent a 'druggable' Achilles' heel for restoring immune control.

Cancer immunotherapy approaches can be passive or active. Passive immunotherapy is mainly used in case of weak or negative immune response and consists of ex vivo-activated cells or molecules that, once re-injected into the body, compensate for missing or deficient immune functions. This approach includes infusion of tumor-specific monoclonal antibodies (mAbs) directed against several targets (i.e., oncogenic pathways and osteoclast functions), infusion of cytokines, and adoptive cell transfer (ACT). Active immunotherapy strategies aim to stimulate in vivo a pre-existing immune response. To apply active immune-therapeutics, the patient's immune system should be able to be competently stimulated and to mediate effector functions. This group includes vaccines, immune checkpoint inhibitors, and oncolytic viruses [182]. 
Since the detailed description of immunotherapeutic strategies goes beyond the aim of this review, we will focus our attention on the most successful treatments of solid tumors, in which CTCs have been investigated as biomarkers for patient monitoring (Table 1).

It is important to note here that most of the primary tumor targets listed below are not specific for CTCs alone. Indeed, some of them have already been detected as soluble markers or circulating tumor DNA (ctDNA) for a selection of tailored treatments, with lower costs and simpler execution as compared to CTC detection. For example, ctDNA was detected with a higher frequency than CTCs in metastatic BC [183]. However, while CTC numbers correlated with prognosis, baseline ctDNA levels did not. This suggests that ctDNA might be more useful in identifying mutations for therapeutic targets, rather than as prognostic biomarker [183].

\subsection{Blocking of Oncogenic Pathways}

Proteins involved in oncogenic pathways are often overexpressed during carcinogenesis and can be targeted to avoid the proliferation of tumor cells [184]. Tumor-specific mAbs induce tumor cell death by directly binding to tumor targets or stimulating antibody-dependent cellular cytotoxicity (ADCC) [185], complement-dependent cytotoxicity (CDC) [186], or antibody-dependent cellular phagocytosis (ADCP) [88]. Examples of mAbs directed against oncogenic pathways are anti-EGFR and anti-HER2.

\subsubsection{EGFR}

The epidermal growth factor receptor (EGFR) is a transmembrane receptor with tyrosine kinase activity that, upon activation by EGF or other ligands, initiates mitogenic signaling across several pathways [187]. Overexpression of EGFR is associated with a more advanced disease and a more unfavorable prognosis; since it occurs in several malignancies, this pathway represents an ideal therapeutic target [188]. Cetuximab (Erbitux, Eli Lilly) was the first mAb prescribed to treat patients with advanced CRC expressing EGFR and was approved by the FDA in 2004. Thereafter, the FDA approved other anti-EGFR mAbs, either as single agents or in combination with other drugs. EGFR expression on CTCs has been demonstrated in patients with advanced breast, prostate, lung, and colorectal cancer by using the CS platform [189-192]. In CTCs from CRC patients, wide intra/interpatient variability in expression and gene amplification levels of EGFR was observed, which might explain differences in treatment response [193]. The persistence of CTCs, enriched and detected by AdnaTest from 38 advanced RAS-BRAF-wild-type CRC patients during treatment with cetuximab-irinotecan or panitumumab, was related to a decrease in OS and PFS [194]. Kuboki et al. demonstrated that a high CTC count assessed by CS predicted a decrease in OS in 63 patients with advanced CRC receiving cetuximab in combination with chemotherapy as third-line treatment, but EGFR expression in CTCs did not predict response to cetuximab [195].

\subsubsection{HER2}

The human epidermal growth factor receptor 2 (HER2, also called HER2/neu or ERB-B2) is a transmembrane glycoprotein receptor with intracellular tyrosine kinase activity. Upon ligand binding, HER2 activates the PI3K/ Akt signaling pathway, leading to cell proliferation and survival. HER2 gene amplification was initially reported in almost 30\% of primary BC patients [196]. Trastuzumab (Herceptin, Genentech) is the first humanized IgG1-class mAb indicated for the treatment of HER2-amplified BC and was approved by the FDA in 1998.

HER2 expression on CTCs has been extensively tested in BC patients [197-202]. Notably, Meng and coworkers demonstrated in 24 patients with HER2-negative primary tumors that nearly $40 \%$ acquired a HER2 gene amplification in CTCs during cancer progression; they first obtained proof of concept that patients treated with a Herceptin-containing therapy had a partial or complete response [197]. Zhang et al. observed in 101 metastatic BC patients that HER2 status was different between CTCs and tumor tissues and that, in CTCs, it predicted the outcome of patients receiving 
anti-HER2 therapy. Indeed, about $62 \%$ of histologically HER2-positive patients had HER2-negative CTCs (detected through the CS system) at the time of sampling. Moreover, although all histologically HER2-positive patients received anti-HER2 therapy, the median PFS of HER2-positive CTC patients was significantly longer than that of HER2-negative CTC patients ( 8.5 vs. 3.5 months, $p<0.001)$ [202].

\subsection{Osteoclast Regulation}

Bone metastasis is common in solid tumors, particularly in breast and prostate cancer. It is the result of a complex process, in which tumor and immune cells participate by releasing cytokines and growth factors. The RANK/RANKL/osteoprotegerin (OPG) axis plays a key role in bone turn-over and is deregulated in many tumors. The differentiation and maturation of osteoclasts are mediated by the binding of RANKL to RANK. RANKL is produced by osteoblasts and stromal cells, while RANK is expressed on pre-osteoclasts. The RANK-RANKL interactions are tightly regulated by OPG, which acts as a soluble decoy receptor by preventing the binding of RANKL to RANK and blocking its activation, thereby inhibiting osteoclast genesis [203]. In a mouse model, tumor cells expressing RANK were shown to migrate to the bone, perhaps attracted by RANKL, which is abundantly expressed in this tissue [204]. Santini et al. demonstrated that RANK expression in primary BC is a predictive marker of bone metastasis occurrence and shorter skeletal DFS [205].

The RANK-RANKL interaction is a promising target for mAb immunotherapy in advanced cancer disease. Denosumab (Xgeva, made by Amgen Inc., and Prolia, made by Amgen, Inc.) is a human IgG2 mAb with a high affinity and specificity for human RANKL. By binding to RANKL, it prevents RANKL interaction with RANK (in a similar way to OPG), thus reducing the differentiation, activity, and survival of osteoclasts [206]. Xgeva and Prolia were approved by the FDA, respectively in 2010 and 2011, the former being indicated for the prevention of skeletal-related events in patients with bone metastases from solid tumors, and the latter for the treatment of bone loss in patients with prostate or breast cancer undergoing hormone ablation therapy.

Concerning the expression of RANK on CTCs, Gray et al. analyzed circulating melanoma cells (CMCs) from 56 melanoma patients (40 late-stage and 16 early-stage) for RANK expression through multiparametric flow cytometry. $\mathrm{RANK}^{+} \mathrm{CMC}$ s were detected in 22/40 late-stage and 4/16 early-stage patients. Interestingly, in two patients with $100 \%$ and $75 \% \mathrm{RANK}^{+} \mathrm{CMCs}$, immunofluorescence staining of metastases, which had been removed one month prior to blood collection for CTC analysis, showed only a small fraction $(2 \%)$ of $\mathrm{RANK}^{+}$cells within the tumor. Furthermore, a change in CMC numbers after treatment start was not found, but the percentage of $\mathrm{RANK}^{+} \mathrm{CMC}$ increased after therapy with BRAF inhibitors and this was associated with a shorter PFS, whereas in patients treated with immune checkpoint inhibitors the increase in $\mathrm{RANK}^{+} \mathrm{CMCs}$ was not apparent [43].

\subsection{Immune Checkpoint Inhibitors}

T cell activation is regulated at different levels during immune responses to prevent autoimmunity. The cytotoxic T-lymphocyte associated protein 4 (CTLA-4) and PD-1 immune checkpoint pathways play a key role in peripheral tolerance by operating at different stages of immune responses. CTLA-4 stops potential autoreactive $\mathrm{T}$ cells in the initial phase of naïve $\mathrm{T}$ cell activation, typically inside lymph nodes. Conversely, the PD-1 pathway regulates previously-activated T cells in the later stages of an immune response, primarily in peripheral tissues. As discussed above, cancer cells, which should be recognized and killed by T cells, have developed methods to evade the host's immune system by exploiting peripheral tolerance [207].

\subsubsection{CTLA-4}

CTLA-4 is a key inhibitor receptor that influences T cell function. In resting T cells, CTLA- 4 is located in the intracellular compartment and is transported and expressed on the cell surface only after activation upon CD28 binding to B7-1 (CD80) and B7-2 (CD86) on APCs [208]. Once on the cell surface, the CTLA-4 inhibitory signal is transmitted through the binding of B7-1 and B7-2 on B cells 
and activated monocytes. Compared to CD28, CTLA-4 binds B7 molecules with a higher affinity and blocks further costimulation [209]. CTLA-4, therefore, downregulates T cell responses and APC function, resulting in immune tolerance [210].

Anti-CTLA-4 mAbs inhibit the binding of B7-1 or B7-2 on APCs to CTLA-4 on T cells. The consequent blockade of CTLA-4 signaling prolongs activation of $\mathrm{T}$ cells and restores their proliferation, thus amplifying $\mathrm{T}$ cell-mediated immunity and supporting the patient's antitumor immune response [211]. In 2011, the FDA approved ipilimumab (Yervoy, Bristol-Myers Squibb) for the treatment of metastatic melanoma. To monitor the response to anti-CTLA- 4 mAb treatments in melanoma patients, several immune circulating biomarkers have been evaluated and correlated to patient outcome (MDSCs, Tregs, $\mathrm{CD}^{+}, \mathrm{CD}^{+}$, and $\mathrm{CD}^{+} \mathrm{T}$ cells) [212-215].

Studies that use CTCs as biomarkers during anti-CTLA- 4 mAb treatments are few. Khoja et al. and Klinac et al. employed CMCs as treatment response biomarkers in patients with melanoma receiving ipilimumab and/or other drugs, respectively using the CS and a manual multimarker immunomagnetic enrichment assay followed by microscopy quantification; however, in both cases the number of considered patients was insufficient to draw reliable conclusions [216,217]. Recently, Hong and collaborators isolated CMCs, by means of microfluidic enrichment, from 16 metastatic melanoma patients undergoing therapy with ipilimumab, and developed a CTC scoring assay to evaluate a 19-gene digital RNA signature. They showed that the use of this quantitative CTC score applied to the serial monitoring of patients was predictive of long-term response to immunotherapy, thus offering an alternative to the analysis of repeated tumor biopsies, which are invasive and insufficiently precise to guide new or ongoing treatments [218]. However interesting as these approaches are, to clarify the role of CMCs/CTCs in the monitoring of patients treated with anti-CTLA-4 mAbs, further studies are needed in large, well-defined subgroups of patients undergoing the same treatment regimen.

\subsubsection{The PD-1/PD-L1 Axis}

As discussed above, a tumor overexpressing PD-L1 protects itself from $\mathrm{T}$ cells, leading to exhaustion and neutralization. The PD-1/PD-L1 inhibitors prevent the PD-1/PD-L1 interaction, thus facilitating an efficacious immune response against the tumor. Clinical studies indicated that antibodies that block PD-1 and PD-L1 have a reliable effect on many advanced malignancies [219]. The PD-1 blockers pembrolizumab (Keytruda, Merck \& Co., Inc., Kenilworth, NJ, USA) and nivolumab (Opdivo, Bristol-Myers Squibb Company, New York, NY, USA) were approved by the FDA in 2014 for patients with advanced melanoma and have subsequently been approved for other cancer types.

PD-L1 can be detected by immunohistochemistry on tumor or immune cells; however, the utility of this marker in predicting which patients might benefit from immune checkpoint inhibitors is controversial [220]. Indeed, since most PD-L1 positive tumors are not affected by anti-PD-1/PD-L1 therapy, the predictive value of PD-L1 in tumor biopsies is so low that it is unacceptable to use as a biomarker in treatment selection [221]. Furthermore, a discordant PD-L1 expression between primary tumors and metastases was observed [222].

Mazel and colleagues first reported the expression of PD-L1 in CTCs from 16 patients with $\mathrm{HR}^{+}$, HER2- metastatic BC, as assessed by the CS platform. CTCs expressing PD-L1 ranged from 0.2 to $100 \%$ and PD-L1 intensity varied between different patients and between CTCs within the same sample. The authors supposed that PD-L1 ${ }^{+}$CTCs might be able to escape the immune system control and, therefore, represent a target for anti-PD-L1 therapies [147].

To understand whether CTCs that express PD-L1 could represent a predictive biomarker during anti-PD-1 therapy, Nicolazzo and colleagues investigated the expression of PD-L1 in CTCs from 24 patients with metastatic NSCLC treated with nivolumab and deduced that it assumes a predictive significance after several months from the beginning of the therapy [148]. Recently, many papers have been published in which the expression of PD-L1 on CTCs has been studied in patients undergoing immunotherapy $[148,149,168,169]$. Despite the different CTC enrichment and enumeration platforms 
and PD-L1 expression assays, the majority of these studies agree in affirming that a high PD-L1 ${ }^{+}$CTC burden is associated with worse OS and PFS [148,149,167,170]. However, it seems premature to draw definitive conclusions because of the low number of analyzed patients.

In Section 4.3.1, we cited the paper by Hong et al. describing a novel method based on a digital RNA signature and a CTC scoring assay to predict patient response to ipilimumab. Noteworthy, the authors also successfully tested their CTC score on samples from 33 melanoma patients receiving pembrolizumab, hence showing the potential clinical validity of this use of CMCs/CTCs as a noninvasive biomarker in cancer immunotherapy [218].

\subsection{Adoptive Cell Transfer (ACT)}

ACT has been proven to be an effective immunotherapeutic method for the treatment of cancer and has achieved promising results in anticancer clinical trials [223]. One of the first anticancer ACT therapies was based on infusion of tumor infiltrating lymphocytes (TILs) for the treatment of melanoma [224] and obtained an objective response rate of 49-72\% when the preparative chemotherapy-induced lymphocytic depletion was performed before TIL infusion [225]. Other ACT-based approaches use CTLs, NK cells, genetically-engineered lymphocytes expressing highly active TCRs, and chimeric antigen receptors (CARs) [226]. In NK cell-based immunotherapy, some studies have shown a decrease in the number of CTCs, which appears to be associated with treatment efficacy and positive patient outcome [227-229]. In particular, Liang et al. compared two groups of patients with recurrent BC, the first $(n=18)$ treated with autogeneic NK cells and the second $(n=18)$ with allogeneic NK cells. In the group treated with allogeneic NK cells, they found that the number of CTCs, enriched by immunomagnetic sorting and counted by FACS, decreased significantly (from $13.13 \pm 5.83$ before treatment to $6.88 \pm 4.95$ one month after the final transfusion, $p=0.01$ ). In contrast, changes in CTC levels in the group treated with autogeneic NK cells were not significant $(p>0.05)$ [227]. Using the same enrichment and counting systems, CTCs have also been studied to evaluate allogeneic NK cell-based ACT in stage IV NSCLC patients $(n=31)$. Lin et al. observed a decrease in CTC numbers, from $27.12 \pm 9.286$ one day before treatment to $14.02 \pm 5.872$ at 30 days after the treatment [228]. Qin et al. also observed a decrease in CTC counts in stage II-IV hepatic carcinoma patients $(n=16)$ one month after immunotherapy with allogeneic NK cells [229].

\subsection{Cancer Vaccines}

A large number of therapeutic vaccines against cancer have shown only little effect, perhaps due to the use of non-mutated self antigens (unable to mediate effective antitumor responses), monovalent antigen-targeting strategies that may select resistant tumor variants, or suboptimal delivery systems that resulted in weak and short-lived antigen-specific T cell responses. A further obstacle is represented by a highly immunosuppressive tumor microenvironment [230].

The identification and validation of predictive biomarkers that accurately reflect immune responses in tissues, including tumors, will be important future tasks of the Human Vaccines Project [231]. Some studies have already been published on the use of CTCs for this purpose. Stojadinovich et al. detected CTCs (by CS) in patients without clinical evidence of BC but at high risk of recurrence. Patients were immunized with the E75-peptide vaccine and a significant reduction in both total CTCs and HER2/neu ${ }^{+}$CTCs was demonstrated over the course of vaccination. These preliminary data suggest that enumeration of CTCs might serve as a surrogate marker to monitor the immunologic response to BC-targeting vaccines [232].

\subsection{Immunotherapies Targeting CTCs}

We have seen that CTCs were proven to be useful prognostic markers and that researchers are working assiduously to define their predictive utility. In this last paragraph, we report some preliminary studies on immunotherapies against CTCs. These studies, performed in vitro or in murine models, give an idea of the variety of targets and strategies that can be considered in cancer therapy. 
The anti-CD44 antibody RG7356 prevented tumor cell adhesion to hyaluronic acid in vitro and caused tumor growth inhibition in vivo in xenograft models using cell lines expressing the CD44s isoform [233]. It has also been demonstrated that CD44-targeting in xenografts results in tumor cell phagocytosis mediated by macrophages. It has been supposed that the RG7356-based treatment induces an upregulation of cytokines and chemoattractants that recruit and activate TAMs [234]. Although TAMs mainly promote tumor progression, it has recently been shown that they are able to phagocytize tumor cells in the presence of mAbs targeting specific tumor antigens [235].

In primary human bladder cancer, a marked expression of CD47 was seen in CD44 tumor initiating cells (TICs) that escape phagocytosis. In the same study, an anti-CD47 mAb restored the ability of macrophages to phagocytize TICs in vitro [236].

Monoclonal and recombinant antibodies have been used to directly target $\mathrm{EpCAM}^{+}$cells [237-240]. A recombinant vaccinia virus expressing full-length EpCAM (VV GA733-2) was able to promote macrophage-mediated ADCC of antigen-positive CRC targets in a murine model [241]. Although promising results were obtained in preclinical studies, the efficacy of EpCAM-directed mAbs and of VV GA733-2 still remains to be demonstrated through large clinical trials [242].

Other preliminary studies could have interesting implications in CTC research. Gül et al. showed in mice inoculated with B16F10 melanoma cells that unstimulated Kupffer cells could bind, but not eliminate tumor cells circulating into the liver; interestingly, when stimulated with a tumor-specific, anti-gp75 mAb, Kupffer cells efficiently removed tumor cells in an ADCP-mediated manner. Phagocytosis of tumor cells was dependent on both the high-affinity IgG-binding Fc $\gamma$ receptor I (Fc $\gamma$ RI) and on the low-affinity Fc $\gamma$ RIV, and resulted in inhibition of liver metastasis [88]. Mitchell et al. developed peripheral blood leukocytes coated with liposomes previously conjugated with E-selectins and TNF-related apoptosis inducing ligand (TRAIL). When mice intravenously inoculated with tumor cells were treated with the functionalized leukocytes, intercepted cancer cells in the circulation underwent TRAIL-mediated apoptosis. Since the cytotoxic activity of these leukocytes resembled that of NK cells, they were named 'unnatural killer cells' [243]. In conclusion, these two examples may represent promising therapeutic strategies to improve the immune antitumor intervention in CTC-positive cancer patients.

\section{Future Opportunities}

Compared with the scenario delineated at the end of the last century, modern oncology has made an epochal breakthrough in patient treatment: the findings of molecular oncology now allow selection of the best treatment for individual patients at any time during disease evolution, maximizing the results and minimizing the side effects. Immunotherapy represents a further improvement, because it permits manipulation of the immune system in order to stimulate recognition and elimination of cancer cells, leaving intact normal surrounding tissues.

However, as in all the best stories, evil is lurking and promises to complicate matters. In our case, the challenge is represented by heterogeneity and plasticity of the tumor that, under pressure from treatment with a targeted drug, is able to evade towards alternative, yet-unexplored pathways, or to favor the growth of a minority of tumor cells insensitive to the ongoing treatment. The only option, in this not-so-unusual case, is to recognize as early as possible the incoming resistance and to change treatment.

Alternatively, we should combine different drugs to target, at the same time, different tumor cell subsets at the lowest dose sufficient to reduce tumor burden without inducing resistance and limit side effects of the drug combination. The cooperative support of immunotherapy, focused on eliminating damaged cancer cells, also promises, in principle, a successful eradication of microscopic groups of tumor cells. The utility of this kind of therapeutic strategy needs to undergo the proof of facts, in ad hoc designed clinical studies based on a robust group of biomarkers. 
For the reason explained in the introduction, we believe that CTCs are a good point of observation of tumor evolution and research on the interplay between CTCs and the immune system might be useful to control tumor growth and, hopefully, block it.

By reviewing the literature, we showed that most cell populations of the immune system interact with CTCs, conditioning their shedding from the primary tumor, survival, homing, or even their further growth. In principle, the ambiguous relationship between CTCs and the immune system, with its antior protumor functions depending on the context, might be a resource rather than a problem if we are able to manipulate the immune system to our scope. The main lesson is that any interaction with the immune system as well as any characteristic of CTCs might be transformed into an Achilles' heel of the tumor.

In the near future, the knowledge on the metastatic mechanisms that we are gaining from studies on CTCs will allow the implementation of a growing number of immunotherapeutic strategies-some of these options are already real. For example, in 2004, Mosolits et al. identified a promising anti-EpCAM vaccine: they treated 13 CRC patients with an anti-EpCAM vaccine $(n=7)$ or an anti-idiotypic antibody mimicking $\operatorname{EpCAM}(n=6)$ in combination with GM-CSF. They detected a long-lasting EpCAM-specific proliferative T cell response in the first group compared to the second [244]. In a more recent work, Choi and coworkers showed that vaccines based on DCs pulsed with EpCAM peptides elicit a strong antigen-specific CTL response and result in a significant suppression of tumor growth in a mouse model. This study, performed with the human hepatoma cell line HepG2, suggests that peptides from cancer stem cells (CSCs) might be a source of antigens for vaccination-based immunotherapy, with the aim to eliminate the CSCs responsible for tumor relapse [245].

On the other hand, since the EMT process is thought to play a role in tumor progression and therapy resistance, immunotherapies directed against tumor cells undergoing EMT are being investigated. The vaccines directed against brachyury, a transcription factor that is associated with tumor EMT, represent an example (Table 1). As reviewed in detail in the work by Hamilton and colleagues, these vaccines are an attractive therapeutic strategy to be used in combination with other treatments [246].

Finally, research on CTCs and immunotherapy of tumors will soon benefit from the extraordinary advances recently achieved in the fields of genomics and transcriptomics, at both a molecular and a computational level. High-throughput technologies, such as next-generation sequencing (NGS), and computational tools for data analysis are now available to study tumor escape mechanisms and to unveil still unknown interactions between tumor and immune cells [247]. Strikingly, these technologies can also be applied to CTCs. For example, single-cell RNA-Seq is already being used to investigate origin, phenotype, and drug resistance pathways of CTCs [248,249].

It has recently been reported that a new procedure, based on the collection of a large volume of peripheral blood (the Diagnostic Leucapheresis), increases the total number of collected CTCs up to 30 fold, thus promising to make high-throughput technologies usable tools for the great majority of patients [250].

Future possible applications of these tools could allow, for instance, the discovery of new interactions between CTCs and the immune system; potentially-immunogenic neoantigens on CTCs in order to target them and/or the primary tumor by means of immunotherapy; neoantigens on CTCs that might reduce the success rate of immunotherapies recognizing only the original antigen (but not the mutated form); other escape mechanisms on CTCs that are shared with the primary tumor; and specific molecular targets on CTCs (rather than on biopsies) to identify and stratify patients who would benefit from immunotherapy. As demonstrated with the work by Hong et al. (which we discussed above), such innovative approaches can also allow us to follow CTC dynamics and reinforce the predictive value of CTCs as a biomarker for serial monitoring of patients during immunotherapies and other treatments [218].

Thus, by combining cancer immunotherapy with molecular and computational genomic tools applied to CTCs, we could move personalized diagnosis and therapy of cancer to the next level. 
Table 1. List of clinical trials where CTCs are being/have been investigated in patients undergoing cancer immunotherapies. The list is based on the ClinicalTrials.gov database as of August 2018.

\begin{tabular}{|c|c|c|c|c|c|c|c|c|c|c|c|}
\hline Trial Number & Official Title & $\begin{array}{l}\text { Study } \\
\text { Type }\end{array}$ & Status & Phase & $\begin{array}{l}\text { Estimated/ } \\
\text { Actual } \\
\text { Enrollment }\end{array}$ & Disease & $\begin{array}{l}\text { CTC/Other } \\
\text { Biomarker } \\
\text { Measurem. } \\
\text { Method }\end{array}$ & $\begin{array}{c}\text { Outcome } \\
\text { Measures/Objectives }\end{array}$ & $\begin{array}{l}\text { Sponsor/ } \\
\text { Collaborators }\end{array}$ & $\begin{array}{l}\text { Start/ } \\
\text { Completion } \\
\text { Date }\end{array}$ & Publications \\
\hline NCT03515798 & $\begin{array}{l}\text { A Prospective Multicenter Open-label, } \\
\text { Randomized Phase II Study of } \\
\text { Pembrolizumab in Combination with } \\
\text { Neoadjuvant (F)EC-Paclitaxel Regimen in } \\
\text { HER2-negative Inflammatory Breast Cancer }\end{array}$ & Int & $\begin{array}{c}\text { Not yet } \\
\text { recruiting }\end{array}$ & Phase 2 & 81 & $\begin{array}{l}\text { Inflammatory } \\
\text { breast } \\
\text { cancer }\end{array}$ & NP & $\begin{array}{l}\text { Evaluation of: pathological } \\
\text { CR and DLT rates, IDFS, EFS, } \\
\text { and OS; PD-L1 expression in } \\
\text { pre-, per-, and post-treatment } \\
\text { tissue. Occurrence of adverse } \\
\text { events. Measurement of } \\
\text { baseline CTCs for prospective } \\
\text { validation of their prognostic } \\
\text { value in IIC; disease } \\
\text { monitoring (ctDNA } \\
\text { sequencing). Identification of } \\
\text { mechanisms of treatment } \\
\text { resistance (immune profiling, } \\
\text { NGS, and mouse xenografing) }\end{array}$ & $\begin{array}{l}\text { Institut } \\
\text { Paoli-Calmettes; } \\
\text { MSD France }\end{array}$ & $\begin{array}{l}\text { June } \\
\text { 2018-April } \\
2025\end{array}$ & NP \\
\hline NCT03213041 & $\begin{array}{l}\text { I-CURE-1: A Phase II, Single Arm Study of } \\
\text { Pembroluzimab Combined with Carboplatin } \\
\text { in Patients with Circulating Tumor Cells } \\
\text { (CTCs) Positive Her-2 Negative Metastatic } \\
\text { Breast Cancer (MBC) }\end{array}$ & Int & Recruiting & Phase 2 & 100 & $\begin{array}{l}\text { Metastatic } \\
\text { breast } \\
\text { cancer }\end{array}$ & $\begin{array}{l}\text { CellSearch, } \\
\text { CellSieve, } \\
\text { sequencing }\end{array}$ & $\begin{array}{l}\text { Evaluation of: PFS, OS, ORR, } \\
\text { CBR, immune-related } \\
\text { response, immune-related } \\
\text { clinical benefitit TTNM in } \\
\text { CTC-positive mBC patients } \\
\text { previously treated with } \\
\text { anthracyclines and taxanes } \\
\text { undergoing treatment with } \\
\text { carboplatin-pembrolizumab; } \\
\text { ORR and CBR in relation to } \\
\text { PD-L1 expression in tissue } \\
\text { and CCTS. Measurement of: } \\
\text { PD-L1 in CCCs and immune } \\
\text { cells such as CAMLs and their } \\
\text { correlation with therapeutic } \\
\text { benefit. Measurement of } \\
\text { ctDNA and sequencing } \\
\text { annlysis of TCR and their } \\
\text { correlation with CTC } \\
\text { enumeration and therapeutic } \\
\text { benefit }\end{array}$ & $\begin{array}{l}\text { Northwestern } \\
\text { University; } \\
\text { Merck Sharp \& } \\
\text { Dohme Corp.; } \\
\text { National } \\
\text { Cancer } \\
\text { Institute (NCI) }\end{array}$ & $\begin{array}{c}\text { September } \\
\text { 2017-July } 2022\end{array}$ & NP \\
\hline NCT03434912 & $\begin{array}{l}\text { Identification and Evaluation of the Potential } \\
\text { Biomarkers on Circulating Tumor Cells and } \\
\text { Tumor Related Rare Cells in Cancer Patients } \\
\text { Undergoing Immunotherapy }\end{array}$ & Obs & Recruiting & $\mathrm{NP}$ & 80 & NP & NP & $\begin{array}{l}\text { Isolation and analysis of } \\
\text { CTCs and tumor-related rare } \\
\text { cells before and after } \\
\text { immunotherapy. } \\
\text { Identification of potential } \\
\text { biomarkers associated with } \\
\text { clinical outcome. Association } \\
\text { between changes of rare } \\
\text { tumor cells and clinical } \\
\text { outcome }\end{array}$ & $\begin{array}{c}\text { MiCareo } \\
\text { Taiwan Co., } \\
\text { Ltd.; Taipei } \\
\text { Veterans } \\
\text { General } \\
\text { Hospital; } \\
\text { Taiwan }\end{array}$ & $\begin{array}{c}\text { May } \\
\text { 2017-April } \\
2020\end{array}$ & NP \\
\hline
\end{tabular}


Table 1. Cont.

\begin{tabular}{|c|c|c|c|c|c|c|c|c|c|c|c|}
\hline Trial Number & Official Title & $\begin{array}{l}\text { Study } \\
\text { Type }\end{array}$ & Status & Phase & $\begin{array}{l}\text { Estimated/ } \\
\text { Actual } \\
\text { Enrollment }\end{array}$ & Disease & $\begin{array}{l}\text { CTC/Other } \\
\text { Biomarker } \\
\text { Measurem. } \\
\text { Method }\end{array}$ & $\begin{array}{c}\text { Outcome } \\
\text { Measures/Objectives }\end{array}$ & $\begin{array}{c}\text { Sponsor/ } \\
\text { Collaborators }\end{array}$ & $\begin{array}{l}\text { Start/ } \\
\text { Completion } \\
\text { Date }\end{array}$ & Publications \\
\hline NCT03070002 & $\begin{array}{l}\text { A Phase II, Open Label Study to Evaluate } \\
\text { Denosumab in Patients with ER and/or } \\
\text { PR-Positive, HER2-Negative Metastatic } \\
\text { Breast Cancer (MBC) With Bone Metastases } \\
\text { and Detectable Circulating Tumor } \\
\text { Cells (CTCs) }\end{array}$ & Int & Recruiting & Phase 2 & 42 & $\begin{array}{l}\text { Metastatic } \\
\text { breast } \\
\text { cancer }\end{array}$ & NP & $\begin{array}{l}\text { Assessment of: the effect of } \\
\text { denosumab in patients with } \\
\text { bone metastases and } \geq 5 \\
\text { CTCS who are in PR or SD } \\
\text { after starting systemic } \\
\text { therapy by measuring the } \\
\text { fraction of patients with } \\
\text { reduction in CTCs; the effect } \\
\text { of denosumab on CTC } \\
\text { enumeration considered as } \\
\text { a continuous variable } \\
\text { (percent change from } \\
\text { baseline); median-PFS } \\
\text { through statistical analysis } \\
\text { evaluating the relationshipp } \\
\text { between longitudinal CTC } \\
\text { counts and PFS; the effect on } \\
\text { CTC profiling and } \\
\text { characterization of stem cell } \\
\text { phenotype (CTC-EMT); the } \\
\text { type of PD. Analysis of } \\
\text { RANKL expression }\end{array}$ & $\begin{array}{l}\text { Northwestern } \\
\text { University; } \\
\text { Amgen; } \\
\text { National } \\
\text { Cancer } \\
\text { Institute (NCI) }\end{array}$ & $\begin{array}{l}\text { March } \\
\text { 2017-March } \\
2022\end{array}$ & NP \\
\hline NCT02978118 & $\begin{array}{l}\text { Exploring Relevant Immune-based } \\
\text { Biomarkers and Circulating Tumor Cells } \\
\text { During Treatment with Immune Checkpoint } \\
\text { Inhibitors in Genitourinary Malignancies }\end{array}$ & Obs & Recruiting & NP & 10 & $\begin{array}{l}\text { Metastatic } \\
\text { renal cell } \\
\text { carcinoma } \\
\text { and } \\
\text { metastatic } \\
\text { urothelial } \\
\text { carcinoma }\end{array}$ & NP & $\begin{array}{l}\text { Evaluation of: change in the } \\
\text { number of T celll, B cells, } \\
\text { myeloid cells before and after } \\
\text { treatment with immune } \\
\text { therapies; number of patients } \\
\text { with detectable CTCS; } \\
\text { prevalence of TILs and TAMs } \\
\text { at baseline; change in CTCs } \\
\text { over time; distribution of CTC } \\
\text { difference scores across tumor } \\
\text { response categories of CR, PR, } \\
\text { SD, and PD }\end{array}$ & $\begin{array}{l}\text { Duke } \\
\text { University; } \\
\text { University of } \\
\text { Wisconsin, } \\
\text { Madison }\end{array}$ & $\begin{array}{c}\text { March } \\
\text { 2017-March } \\
\text { 2019 }\end{array}$ & NP \\
\hline NCT02948985 & $\begin{array}{l}\text { Evaluation of Individual Peripheral Blood } \\
\text { Circulating Tumor Cells Combined with } \\
\text { Tumor Marker Detection of Efficacy of } \\
\text { Chemotherapy in Patients with Advanced } \\
\text { Colorectal Cancer: An Observational } \\
\text { Clinical Trial }\end{array}$ & Obs & $\begin{array}{c}\text { Not yet } \\
\text { recruiting }\end{array}$ & NP & 100 & $\begin{array}{l}\text { Metastatic } \\
\text { colorectal } \\
\text { cancer }\end{array}$ & $\begin{array}{l}\text { SE-iFISH, } \\
\text { BEAMing }\end{array}$ & $\begin{array}{l}\text { Correlation of: RAS status on } \\
\text { CTCs with clinical outcome of } \\
\text { patients with } \\
\text { histologically-confirmed RAS } \\
\text { and B-Raf wild-type mCRC } \\
\text { treated with FOLFIII } \pm \\
\text { cetuximab; mutations in } \\
\text { ctDNA with } \\
\text { cetuximab resistance }\end{array}$ & $\begin{array}{l}\text { Shanghai } \\
\text { General } \\
\text { Hospital; } \\
\text { Shanghai Jiao } \\
\text { Tong } \\
\text { University } \\
\text { School of } \\
\text { Medicine }\end{array}$ & $\begin{array}{l}\text { January } \\
\text { 2017-December } \\
\text { 2019 }\end{array}$ & NP \\
\hline
\end{tabular}


Table 1. Cont.

\begin{tabular}{|c|c|c|c|c|c|c|c|c|c|c|c|}
\hline Trial Number & Official Title & $\begin{array}{l}\text { Study } \\
\text { Type }\end{array}$ & Status & Phase & $\begin{array}{l}\text { Estimated/ } \\
\text { Actual } \\
\text { Enrollment }\end{array}$ & Disease & $\begin{array}{l}\text { CTC/Other } \\
\text { Biomarker } \\
\text { Measurem. } \\
\text { Method }\end{array}$ & $\begin{array}{c}\text { Outcome } \\
\text { Measures/Objectives }\end{array}$ & $\begin{array}{c}\text { Sponsor/ } \\
\text { Collaborators }\end{array}$ & $\begin{array}{l}\text { Start/ } \\
\text { Completion } \\
\text { Date }\end{array}$ & Publications \\
\hline NCT03114631 & $\begin{array}{l}\text { Single-center Trial Evaluating the Safety and } \\
\text { Efficacy of MUC-1/WT-1 Peptide or Tumor } \\
\text { Lysate-pulsed Dendritic Cell } \\
\text { Immunotherapy for the Patients with } \\
\text { Pancreatic Cancer }\end{array}$ & Int & Recruiting & $\begin{array}{l}\text { Phase } 1 \\
\text { and phase } \\
2\end{array}$ & 30 & $\begin{array}{l}\text { Pancreatic } \\
\text { cancer }\end{array}$ & NP & $\begin{array}{l}\text { Assessment of: number of } \\
\text { participants with PR or CR at } \\
1 \text { year; number of participants } \\
\text { who survivived at } 1,2,3 \text { years } \\
\text { or more; immune response } \\
\text { (increase of antigen-specific T } \\
\text { cells, decrease of Tregs and } \\
\text { other cell subsets associated } \\
\text { with tumor progression); CTC } \\
\text { count (decrease of EpCAM } \\
\text { CD45 } \\
\text { CTCS) }\end{array}$ & $\begin{array}{c}\text { The } \\
\text { Republican } \\
\text { Research and } \\
\text { Practical } \\
\text { Center for } \\
\text { Epidemiology } \\
\text { and } \\
\text { Microbiology; } \\
\text { Belarusian } \\
\text { state medical } \\
\text { university } \\
\end{array}$ & $\begin{array}{l}\text { January } \\
\text { 2017-December } \\
\text { 2019 }\end{array}$ & NP \\
\hline NCT02456571 & $\begin{array}{l}\text { Defining the Relevant Immune Checkpoints } \\
\text { Expressed on Metastatic Prostate Cancer } \\
\text { Circulating Tumor Cells }\end{array}$ & Obs & Recruiting & $\mathrm{NP}$ & 40 & $\begin{array}{l}\text { Metastatic } \\
\text { prostate } \\
\text { cancer }\end{array}$ & CellSearch & $\begin{array}{l}\text { Evaluation of: change in } \\
\text { expression of PD-L1, PD-L2, } \\
\text { B7-H3, and CTLA-4 on CTCs } \\
\text { of four groups of patients } \\
\text { undergoing different } \\
\text { treatments; change over time } \\
\text { in mutational profiles, } \\
\text { AR-variant expression and } \\
\text { immune tumor-related RNA } \\
\text { signatures in CTC-enriched } \\
\text { blood; expression } \\
\text { (prevalence) of PD-L1, PD-L2, } \\
\text { B7-H3, and CTA-4 in } \\
\text { metastatic tumor tissue } \\
\text { obtained by elective CT or } \\
\text { US-guided research biopsies } \\
\text { in up to } 10 \text { patients and } \\
\text { comparison of this expression } \\
\text { percentage with CTC immune } \\
\text { checkpoint expression }\end{array}$ & $\begin{array}{l}\text { Duke } \\
\text { University; } \\
\text { Janssen } \\
\text { Research \& } \\
\text { Development, } \\
\text { LLC }\end{array}$ & $\begin{array}{c}\text { November } \\
\text { 2016-June } 2019\end{array}$ & NP \\
\hline
\end{tabular}


Table 1. Cont.

\begin{tabular}{|c|c|c|c|c|c|c|c|c|c|c|c|}
\hline Trial Number & Official Title & $\begin{array}{l}\text { Study } \\
\text { Type }\end{array}$ & Status & Phase & $\begin{array}{l}\text { Estimated/ } \\
\text { Actual } \\
\text { Enrollment }\end{array}$ & Disease & $\begin{array}{l}\text { CTC/Other } \\
\text { Biomarker } \\
\text { Measurem. } \\
\text { Method }\end{array}$ & $\begin{array}{c}\text { Outcome } \\
\text { Measures/Objectives }\end{array}$ & $\begin{array}{c}\text { Sponsor/ } \\
\text { Collaborators }\end{array}$ & $\begin{array}{l}\text { Start/ } \\
\text { Completion } \\
\text { Date }\end{array}$ & Publications \\
\hline NCT02933255 & $\begin{array}{l}\text { Phase I/II Study of PROSTVAC in } \\
\text { Combination with Nivolumab in Men With } \\
\text { Prostate Cancer }\end{array}$ & Int & Recruiting & $\begin{array}{l}\text { Phase } 1 \\
\text { and } \\
\text { phase } 2\end{array}$ & 29 & $\begin{array}{l}\text { Prostate } \\
\text { cancer }\end{array}$ & NP & $\begin{array}{l}\text { Evaluation of: safety and } \\
\text { changes in T cell infiltration in } \\
\text { the tumor after neoadjuvant } \\
\text { treatment; hange in } \\
\text { peripheral PSA-specific T } \\
\text { cells in patients treated with } \\
\text { PROSVAC and nivolumab; } \\
\text { intraprostatic Treg infiltration } \\
\text { with CD4 and FOX-P3 } \\
\text { stainings; PSA changes } \\
\text { secondary to vaccination, } \\
\text { including rate of biochemical } \\
\text { recurrence after } \\
\text { prostatectomy; MRI changes } \\
\text { secondary to treatment; } \\
\text { changes in PD-L1 expression; } \\
\text { pathologic responses } \\
\text { (including pathologic CR); } \\
\text { changes in immune cell } \\
\text { subsets in the periphery; } \\
\text { changes in soluble } \\
\text { immune-mediating factors } \\
\text { (such as cytokines, etc.) in } \\
\text { sera; changes in CTC levels in } \\
\text { mCRPC cohort }\end{array}$ & $\begin{array}{c}\text { National } \\
\text { Cancer } \\
\text { Institute (NCI); } \\
\text { National } \\
\text { Institutes of } \\
\text { Health Clinical } \\
\text { Center (CC) }\end{array}$ & $\begin{array}{l}\text { October } \\
\text { 2016-August } \\
2021\end{array}$ & NP \\
\hline NCT02915445 & $\begin{array}{l}\text { T Cells Armed with Chimeric Antigen } \\
\text { Receptor Recognizing EpCAM for Patients } \\
\text { With Nasopharyngeal Carcinoma and } \\
\text { Breast Cancer }\end{array}$ & Int & Recruiting & Phase 1 & 30 & $\begin{array}{l}\text { Nasopharyngeal } \\
\text { carcinoma } \\
\quad \text { or } \\
\text { breast cancer }\end{array}$ & al & $\begin{array}{l}\text { Evaluation of: number of } \\
\text { participants with } \\
\text { treatment-related adverse } \\
\text { events/dose-limiting toxicity } \\
\text { as assessed by CTCAE v4.0; } \\
\text { RR of participants treated } \\
\text { with EpCAM } \\
\text { assessed by RECIRT-T cells } \\
\text { persistence of EpCAM } 1 \text {; } \\
\text { CAR-T cells and correlation } \\
\text { with the RR; persistence of } \\
\text { EpCAM } \\
\text { EpCTCs }\end{array}$ & $\begin{array}{l}\text { Sichuan } \\
\text { University }\end{array}$ & $\begin{array}{l}\text { July 2016-July } \\
2019\end{array}$ & NP \\
\hline NCT02827344 & $\begin{array}{l}\text { Feasibility Study of PD-L1 Expression } \\
\text { Analysis on Circulating Tumor Cells by } \\
\text { Immunocytochemistry and MDSCs Level } \\
\text { Evolution Analysis in Non-small Cell Lung } \\
\text { Cancer Treated With PD-L1 or PD1 Inhibitor }\end{array}$ & Obs & $\begin{array}{l}\text { Unknown } \\
\text { status }\end{array}$ & NP & 51 & $\begin{array}{l}\text { Stage IV } \\
\text { non-small } \\
\text { cell lung } \\
\text { cancer }\end{array}$ & $\begin{array}{l}\text { ISET, } \\
\text { immunocyto } \\
\text { chemistry }\end{array}$ & $\begin{array}{l}\text { Assessment of: feasibility of } \\
\text { analysis of PD-L1 expression } \\
\text { on CTCS; percentage of CTCs } \\
\text { expressing PD-L1 after } 4 \\
\text { cycles of immunotherapy; } \\
\text { evolution of MDSC counts in } \\
\text { response to treatment }\end{array}$ & $\begin{array}{c}\text { University } \\
\text { Hospital, } \\
\text { Toulouse }\end{array}$ & $\begin{array}{c}\text { October } 2015 \\
\text {-October } 2016\end{array}$ & [168] \\
\hline
\end{tabular}


Table 1. Cont.

\begin{tabular}{|c|c|c|c|c|c|c|c|c|c|c|c|}
\hline Trial Number & Official Title & $\begin{array}{l}\text { Study } \\
\text { Type }\end{array}$ & Status & Phase & $\begin{array}{l}\text { Estimated/ } \\
\text { Actual } \\
\text { Enrollment }\end{array}$ & Disease & $\begin{array}{l}\text { CTC/Other } \\
\text { Biomarker } \\
\text { Measurem. } \\
\text { Method }\end{array}$ & $\begin{array}{c}\text { Outcome } \\
\text { Measures/Objectives }\end{array}$ & $\begin{array}{c}\text { Sponsor/ } \\
\text { Collaborators }\end{array}$ & $\begin{array}{l}\text { Start/ } \\
\text { Completion } \\
\text { Date }\end{array}$ & Publications \\
\hline NCT02552394 & $\begin{array}{l}\text { Anti-Prostate-Specific Membrane Antigen } \\
\text { Monoclonal Antibody J591 in Patients with } \\
\text { Advanced Prostate Cancer and Unfavorable } \\
\text { Circulating Tumor Cell Counts }\end{array}$ & Int & Recruiting & Phase 1 & 24 & $\begin{array}{l}\text { Metastatic } \\
\text { prostate } \\
\text { cancer }\end{array}$ & CellSearch & $\begin{array}{l}\text { Assessment of: decrease of } \\
\text { CTC count in mPCa patients } \\
\text { with elevated baseline CTC } \\
\text { counts undergoing mAb } \\
\text { Hu-J591 treatment with } \\
\text { different dose levels; PSA } \\
\text { decline rate across all dose } \\
\text { levels; 897r-DFO--hiJ591 } \\
\text { PET/CT imaging both pre- } \\
\text { and post-mAb hu-J591 } \\
\text { infusion to describe objective } \\
\text { imaging responses; duration } \\
\text { of biochemical and/or } \\
\text { measurable disease response } \\
\text { through PSA dosage and/or } \\
\text { CT scans; number of } \\
\text { participants with } \\
\text { treatment-related adverse } \\
\text { events as assessed by CTCAE } \\
\text { v4.;0; overall and prostate } \\
\text { cancer specific survival rate of } \\
\text { subjects following treatment; } \\
\text { pain change from baseline as } \\
\text { reported on the brief pain } \\
\text { inventory questionnaire }\end{array}$ & $\begin{array}{l}\text { Weill Medical } \\
\text { College of } \\
\text { Cornell } \\
\text { University }\end{array}$ & $\begin{array}{l}\text { July 2015-July } \\
2019\end{array}$ & [251] \\
\hline NCT02510781 & $\begin{array}{l}\text { A Study on Neoadjuvant Therapy for Her-2 } \\
\text { Positive Breast Cancer and the Prognosis by } \\
\text { Detecting Circulating Tumor Cells }\end{array}$ & Int & $\begin{array}{l}\text { Unknown } \\
\text { status }\end{array}$ & Phase 2 & 200 & $\begin{array}{l}\text { Stage II-III } \\
\text { breast } \\
\text { cancer }\end{array}$ & NP & $\begin{array}{l}\text { Assessment of: pCR rate; } \\
\text { clinical response rate; number } \\
\text { of adverse events }\end{array}$ & $\begin{array}{l}\text { Hospital } \\
\text { Affiliated to } \\
\text { Military } \\
\text { Medical } \\
\text { Science, Beijing }\end{array}$ & $\begin{array}{l}\text { January } \\
\text { 2015-December } \\
\text { 2017 }\end{array}$ & NP \\
\hline NCT02179515 & $\begin{array}{l}\text { An Open Label Phase I Study to Evaluate the } \\
\text { Safety and Tolerability of a Modified } \\
\text { Vaccinia Ankara (MVA) Based Vaccine } \\
\text { Modified to Express Brachyury and T-Cell } \\
\text { Costimulatory Molecules (MVA } \\
\text { Brachyury-TRICOM) }\end{array}$ & Int & Completed & Phase 1 & 38 & $\begin{array}{l}\text { Lung, } \\
\text { breast, } \\
\text { prostate, } \\
\text { ovarian } \\
\text { tumors } \\
\text { (others) }\end{array}$ & NP & $\begin{array}{l}\text { Evaluation of: safety and } \\
\text { tolerability of escalating doses } \\
\text { of MVA-brachyury-TRICOM } \\
\text { vaccine; CD8 } 8^{+} \text {and CDI } 4^{+} \text {cell } \\
\text { immunologic response as } \\
\text { measured by an increase in } \\
\text { brachyury-specific T cells; } \\
\text { evidence of clinical benefit } \\
\text { (such as PFS), RECCIST criteria, } \\
\text { reduction in serum markers, } \\
\text { and/or reduction in CTCs; } \\
\text { frequency of immune cell } \\
\text { subsets in peripheral blood } \\
\text { and changes in serum levels } \\
\text { of cytokines and Abs to } \\
\text { brachyury; correlation of } \\
\text { brachyury expression in } \\
\text { tissue samples with } \\
\text { clinical outcomes }\end{array}$ & $\begin{array}{c}\text { National } \\
\text { Cancer } \\
\text { Institute (NCI); } \\
\text { National } \\
\text { Institutes of } \\
\text { Health Clinical } \\
\text { Center (CC) }\end{array}$ & $\begin{array}{l}\text { June } \\
\text { 2014-February } \\
2018\end{array}$ & {$[252,253]$} \\
\hline
\end{tabular}


Table 1. Cont.

\begin{tabular}{|c|c|c|c|c|c|c|c|c|c|c|c|}
\hline Trial Number & Official Title & $\begin{array}{l}\text { Study } \\
\text { Type }\end{array}$ & Status & Phase & $\begin{array}{l}\text { Estimated/ } \\
\text { Actual } \\
\text { Enrollment }\end{array}$ & Disease & $\begin{array}{l}\text { CTC/Other } \\
\text { Biomarker } \\
\text { Measurem. } \\
\text { Method }\end{array}$ & $\begin{array}{c}\text { Outcome } \\
\text { Measures/Objectives }\end{array}$ & $\begin{array}{c}\text { Sponsor/ } \\
\text { Collaborators }\end{array}$ & $\begin{array}{l}\text { Start/ } \\
\text { Completion } \\
\text { Date }\end{array}$ & Publications \\
\hline NCT01804465 & $\begin{array}{l}\text { A Randomized Phase } 2 \text { Trial of Immediate } \\
\text { vs. Delayed Anti-CTLA4 Blockade } \\
\text { Following Sipuleucel-T Treatment for } \\
\text { Prostate Cancer Immunotherapy }\end{array}$ & Int & Recruiting & Phase 2 & 54 & $\begin{array}{l}\text { Prostate } \\
\text { cancer }\end{array}$ & NP & $\begin{array}{l}\text { Evaluation of: impact of the } \\
\text { timing of ipilimumab } \\
\text { administration on } \\
\text { PAP/PA2024-specific immune } \\
\text { responses by Sip; PSA } \\
\text { measurements; radiographic } \\
\text { clinical responses; } \\
\text { modulation of feffector and } \\
\text { regulatory T cells; safety of } \\
\text { combining ipilimumab with } \\
\text { SipT; CTC count; T cell gene } \\
\text { and microRNA signatures }\end{array}$ & $\begin{array}{c}\text { University of } \\
\text { California, San } \\
\text { Francisco; M.D. } \\
\text { Anderson } \\
\text { Cancer Center; } \\
\text { Bristol-Myers } \\
\text { Squibb; } \\
\text { Dendreon }\end{array}$ & $\begin{array}{l}\text { January } \\
\text { 2014-December } \\
2019\end{array}$ & NP \\
\hline NCT02412462 & $\begin{array}{l}\text { Phase I Dose Escalation Study of AB-16B5 in } \\
\text { Subjects with an Advanced } \\
\text { Solid Malignancy }\end{array}$ & Int & Completed & Phase 1 & 15 & $\begin{array}{l}\text { Advanced } \\
\text { solid } \\
\text { malignancies }\end{array}$ & NP & $\begin{array}{l}\text { Assessment of: number of } \\
\text { participants with an adverse } \\
\text { event; plasma concentrations } \\
\text { of AB-16B5; objective tumor } \\
\text { responses in subjects with } \\
\text { measurable disease according } \\
\text { to RECIST. Monitoring of } \\
\text { EMT and stem cell } \\
\text { biomarkers in CTCs and } \\
\text { paired tumor biopsies }\end{array}$ & $\begin{array}{c}\text { Alethia } \\
\text { Biotherapeutics }\end{array}$ & $\begin{array}{l}\text { April } \\
\text { 2015-January } \\
\text { 2017 }\end{array}$ & NP \\
\hline NCT01975142 & $\begin{array}{l}\text { Validity of HER2-amplified Circulating } \\
\text { Tumor Cells to Select Metastatic Breast } \\
\text { Cancer Considered HER2-negative for } \\
\text { Trastuzumab-emtansine (T-DM1) Treatment }\end{array}$ & Int & $\begin{array}{l}\text { Active, not } \\
\text { recruiting }\end{array}$ & Phase 2 & 155 & $\begin{array}{c}\text { Metastatic } \\
\text { breast } \\
\text { cancer } \\
\text { considered } \\
\text { HER2 } \\
\text { negative on } \\
\text { primary } \\
\text { tumor }\end{array}$ & FISH, IF & $\begin{array}{l}\text { Assessment of: tumor } \\
\text { response rate to T-DM1 in } \\
\text { patients with HER2-amplified } \\
\text { CTCs; detection rate of } \\
\text { HER2-amplified CTC; } \\
\text { heterogeneity rate between } \\
\text { CTCs and correlations with } \\
\text { patient characteristics; } \\
\text { technical failure rate and } \\
\text { reproducibility of HER2 FISH } \\
\text { on CTCS; correlation between } \\
\text { HER2 FISH and IF on CTCs; } \\
\text { PFS; disease control rate } \\
\text { (responsive and stable cases); } \\
\text { correlation between treatment } \\
\text { efficacy and HER2 FISH } \\
\text { results; changes in CTC } \\
\text { numbers during treatment; } \\
\text { ctDNA before and during } \\
\text { treatment; toxicity }\end{array}$ & Institut Curie & $\begin{array}{l}\text { October } \\
\text { 2013-November } \\
2017\end{array}$ & [254] \\
\hline NCT02450448 & $\begin{array}{l}\text { The Detection of Circulating Tumor Cells } \\
\text { (CTCs) in Patients with Renal Cancer } \\
\text { Undergoing Cryosurgery Combined With } \\
\text { DC-CIK Treatment }\end{array}$ & Obs & Completed & $\mathrm{NP}$ & 60 & $\begin{array}{l}\text { Stage II-IV } \\
\text { renal } \\
\text { cancer }\end{array}$ & $\begin{array}{l}\text { Multiparameter } \\
\text { FCM and } \\
\text { RT-PCR }\end{array}$ & $\begin{array}{l}\text { Enumeration of CTCs after } \\
\text { cryosurgery in patients } \\
\text { receiving or not receiving } \\
\text { DC-CIK treatment }\end{array}$ & $\begin{array}{l}\text { Fuda Cancer } \\
\text { Hospital, } \\
\text { Guangzhou }\end{array}$ & $\begin{array}{l}\text { June } \\
\text { 2013-December } \\
2015\end{array}$ & NP \\
\hline
\end{tabular}


Table 1. Cont.

\begin{tabular}{|c|c|c|c|c|c|c|c|c|c|c|c|}
\hline Trial Number & Official Title & $\begin{array}{l}\text { Study } \\
\text { Type }\end{array}$ & Status & Phase & $\begin{array}{l}\text { Estimated/ } \\
\text { Actual } \\
\text { Enrollment }\end{array}$ & Disease & $\begin{array}{l}\text { CTC/Other } \\
\text { Biomarker } \\
\text { Measurem. } \\
\text { Method }\end{array}$ & $\begin{array}{c}\text { Outcome } \\
\text { Measures/Objectives }\end{array}$ & $\begin{array}{c}\text { Sponsor/ } \\
\text { Collaborators }\end{array}$ & $\begin{array}{l}\text { Start/ } \\
\text { Completion } \\
\text { Date }\end{array}$ & Publications \\
\hline NCT02450435 & $\begin{array}{l}\text { The Detection of Circulating Tumor Cells } \\
\text { (CTCs) in Patients with Prostatic Cancer } \\
\text { Undergoing Cryosurgery Combined With } \\
\text { DC-CIK Treatment }\end{array}$ & Obs & Completed & NP & 60 & $\begin{array}{l}\text { Stage II-IV } \\
\text { prostatic } \\
\text { cancer }\end{array}$ & $\begin{array}{l}\text { Multiparameter } \\
\text { FCM and } \\
\text { RT-PCR }\end{array}$ & $\begin{array}{l}\text { Enumeration of CTCs after } \\
\text { cryosurgery in patients } \\
\text { receiving or not receiving } \\
\text { DC-CIK treatment }\end{array}$ & $\begin{array}{l}\text { Fuda Cancer } \\
\text { Hospital, } \\
\text { Guangzhou }\end{array}$ & $\begin{array}{l}\text { June } \\
\text { 2013-December } \\
2015\end{array}$ & NP \\
\hline NCT02450422 & $\begin{array}{l}\text { The Detection of Circulating Tumor Cells } \\
\text { (CTCs) in Patients with Colorectal Cancer } \\
\text { Undergoing Cryosurgery Combined With } \\
\text { DC-CIK Treatment }\end{array}$ & Obs & Completed & NP & 60 & $\begin{array}{l}\text { Stage II-IV } \\
\text { colorectal } \\
\text { cancer }\end{array}$ & $\begin{array}{l}\text { Multipa-rameter } \\
\text { FCM and } \\
\text { RT-PCR }\end{array}$ & $\begin{array}{l}\text { Enumeration of CTCs after } \\
\text { cryosurgery in patients } \\
\text { receiving or not receiving } \\
\text { DC-CIK treatment }\end{array}$ & $\begin{array}{l}\text { Fuda Cancer } \\
\text { Hospital, } \\
\text { Guangzhou }\end{array}$ & $\begin{array}{l}\text { June } \\
\text { 2013-December } \\
\text { 2015 }\end{array}$ & NP \\
\hline NCT02450357 & $\begin{array}{l}\text { The Detection of Circulating Tumor Cells } \\
\text { (CTCs) in Patients with Breast Cancer } \\
\text { Undergoing Cryosurgery Combined With } \\
\text { DC-CIK Treatment }\end{array}$ & Obs & Completed & NP & 60 & $\begin{array}{l}\text { Stage II-IV } \\
\text { breast } \\
\text { cancer }\end{array}$ & $\begin{array}{l}\text { Multipa-rameter } \\
\text { FCM and } \\
\text { RT-PCR }\end{array}$ & $\begin{array}{l}\text { Enumeration of CTCs after } \\
\text { cryosurgery in patients } \\
\text { receiving or not receiving } \\
\text { DC-CIK treatment }\end{array}$ & $\begin{array}{l}\text { Fuda Cancer } \\
\text { Hospital, } \\
\text { Guangzhou }\end{array}$ & $\begin{array}{l}\text { June } \\
\text { 2013-December } \\
2015\end{array}$ & NP \\
\hline NCT02416635 & $\begin{array}{l}\text { The Detection of Circulating Tumor Cells } \\
\text { (CTCs) in Patients with Liver Cancer } \\
\text { Undergoing Cryosurgery Combined With } \\
\text { DC-CIK Treatment }\end{array}$ & Obs & Completed & NP & 60 & $\begin{array}{l}\text { Stage II-IV } \\
\text { liver cancer }\end{array}$ & $\begin{array}{l}\text { Multipa-rameter } \\
\text { FCM and } \\
\text { RT-PCR }\end{array}$ & $\begin{array}{l}\text { Enumeration of CTCs after } \\
\text { cryosurgery in patients } \\
\text { receiving or not receiving } \\
\text { DC-CIK treatment }\end{array}$ & $\begin{array}{l}\text { Fuda Cancer } \\
\text { Hospital, } \\
\text { Guangzhou }\end{array}$ & $\begin{array}{l}\text { June } \\
\text { 2013-December } \\
\text { 2015 }\end{array}$ & NP \\
\hline NCT02412384 & $\begin{array}{l}\text { The Detection of Circulating Tumor Cells } \\
\text { (CTCs) in Patients with Lung Cancer } \\
\text { Undergoing Cryosurgery Combined With } \\
\text { DC-CIK Treatment }\end{array}$ & Obs & Completed & NP & 120 & $\begin{array}{l}\text { Stage II-IV } \\
\text { lung cancer }\end{array}$ & $\begin{array}{l}\text { Multipa-rameter } \\
\text { FCM and } \\
\text { RT-PCR }\end{array}$ & $\begin{array}{l}\text { Enumeration of CTCs after } \\
\text { cryosurgery in patients } \\
\text { receiving or not receiving } \\
\text { DC-CIK treatment }\end{array}$ & $\begin{array}{l}\text { Fuda Cancer } \\
\text { Hospital, } \\
\text { Guangzhou }\end{array}$ & $\begin{array}{l}\text { June } \\
\text { 2013-February } \\
2016\end{array}$ & NP \\
\hline NCT02406846 & $\begin{array}{l}\text { The Detection of CTCs in Patients with } \\
\text { Pancreatic Cancer Undergoing Cryosurgery } \\
\text { Combined With DC-CIK Treatment }\end{array}$ & Obs & Completed & NP & 80 & $\begin{array}{l}\text { Stage II-IV } \\
\text { pancreatic } \\
\text { cancer }\end{array}$ & $\begin{array}{l}\text { Multipa-rameter } \\
\text { FCM and } \\
\text { RT-PCR }\end{array}$ & $\begin{array}{l}\text { Enumeration of CTCs after } \\
\text { cryosurgery in patients } \\
\text { receiving or not receiving } \\
\text { DC-CIK treatment }\end{array}$ & $\begin{array}{l}\text { Fuda Cancer } \\
\text { Hospital, } \\
\text { Guangzhou }\end{array}$ & $\begin{array}{l}\text { June } \\
\text { 2013-December } \\
2015\end{array}$ & NP \\
\hline NCT01548677 & $\begin{array}{l}\text { TRastuzumab in HER2-negative Early Breast } \\
\text { Cancer as Adjuvant Treatment for } \\
\text { Circulating Tumor Cells (CTC) (“TREAT } \\
\text { CTC” Trial) }\end{array}$ & Int & Completed & Phase 2 & 1317 & $\begin{array}{l}\text { HER2 } \\
\text { negative } \\
\text { primary } \\
\text { breast } \\
\text { cancer }\end{array}$ & NP & $\begin{array}{l}\text { Detection of CTCs. } \\
\text { Comparison of CTC detection } \\
\text { rate at week } 18 \text { between the } \\
\text { trastuzumab treatment arm } \\
\text { and the observational arm. } \\
\text { Evaluation of: RFI, IDFS, DFS, } \\
\text { and OS; feasibility, reliability, } \\
\text { within-patient reproducibility, } \\
\text { and variability of CTC assays; } \\
\text { correlation of CTC detection } \\
\text { rate with RFI, IDFS, DFS, } \\
\text { and OS; cardiac safety of } \\
\text { trastuzumab treatment }\end{array}$ & $\begin{array}{l}\text { European } \\
\text { Organisation } \\
\text { for Research } \\
\text { and Treatment } \\
\text { of } \\
\text { Cancer-EORTC; } \\
\text { Hoffmann-La } \\
\text { Roche; Janssen } \\
\text { Diagnostics, } \\
\text { LLC; } \\
\text { SUCCESS; } \\
\text { UNICANCER }\end{array}$ & $\begin{array}{l}\text { April } \\
\text { 2013-March } \\
2017\end{array}$ & [255] \\
\hline
\end{tabular}


Table 1. Cont.

\begin{tabular}{|c|c|c|c|c|c|c|c|c|c|c|c|}
\hline Trial Number & Official Title & $\begin{array}{l}\text { Study } \\
\text { Type }\end{array}$ & Status & Phase & $\begin{array}{l}\text { Estimated/ } \\
\text { Actual } \\
\text { Enrollment }\end{array}$ & Disease & $\begin{array}{c}\text { CTC/Other } \\
\text { Biomarker } \\
\text { Measurem. } \\
\text { Method }\end{array}$ & $\begin{array}{c}\text { Outcome } \\
\text { Measures/Objectives }\end{array}$ & $\begin{array}{c}\text { Sponsor/ } \\
\text { Collaborators }\end{array}$ & $\begin{array}{c}\text { Start/ } \\
\text { Completion } \\
\text { Date }\end{array}$ & Publications \\
\hline NCT01640444 & $\begin{array}{l}\text { Randomized Phase II Study to Explore the } \\
\text { Influence of BRAF and PIK3K Status on the } \\
\text { Efficacy of FOLFIRI Plus Bevacizumab or } \\
\text { Cetuximab, as First Line Therapy of Patients } \\
\text { with RAS Wild-type Metastatic Colorectal } \\
\text { Carcinoma and <3 Circulating Tumor Cells }\end{array}$ & Int & $\begin{array}{l}\text { Active, not } \\
\text { recruiting }\end{array}$ & Phase 2 & 240 & $\begin{array}{l}\text { Metastatic } \\
\text { colorectal } \\
\text { cancer }\end{array}$ & NP & $\begin{array}{l}\text { Evaluation of: PFS, OS, RR, } \\
\text { and R0 surgery rate; baseline } \\
\text { CTC count and its correlation } \\
\text { to PFS, , SS, and RR; adverse } \\
\text { events; correlation of } \\
\text { molecular status of } \\
\text { biomarkers related to cellular } \\
\text { and tumoral reproduction } \\
\text { and/or mode of action and } \\
\text { PFS, OS, and RR }\end{array}$ & $\begin{array}{l}\text { Spanish } \\
\text { Cooperative } \\
\text { Group for the } \\
\text { Treatment of } \\
\text { Digestive } \\
\text { Tumours } \\
\text { (TTD); Roche } \\
\text { Pharma AG }\end{array}$ & $\begin{array}{c}\text { July } \\
\text { 2012-November } \\
2018\end{array}$ & NP \\
\hline NCT01640405 & $\begin{array}{l}\text { Phase III, Randomized Clinical Trial to } \\
\text { Evaluate FoLFOX + Bevacizumab Versus } \\
\text { FOLFOXIRI + Bevacizumab as First Line } \\
\text { Treatment of Patients with Metastatic } \\
\text { Colorectal Cancer Not Previously Treated } \\
\text { and With Three or More Circulating } \\
\text { Tumoral Cells }\end{array}$ & Int & $\begin{array}{l}\text { Active, not } \\
\text { recruiting }\end{array}$ & Phase 3 & 350 & $\begin{array}{l}\text { Metastatic } \\
\text { colorectal } \\
\text { cancer }\end{array}$ & NP & $\begin{array}{l}\text { Evaluation of: PFS, OS, RR, } \\
\text { and R0 surgery rate; baseline } \\
\text { CTC count and its correlation } \\
\text { to PFS, OS, and RR; } \\
\text { correlation of RAS, BRAF, } \\
\text { and PISK mutations and PFS, } \\
\text { OS, and RR; adverse events; } \\
\text { correlation of molecular } \\
\text { status of biomarkers related } \\
\text { to cellular and tumoral } \\
\text { reproduction and/or mode of } \\
\text { action and PFS, OS, and RR }\end{array}$ & $\begin{array}{l}\text { Spanish } \\
\text { Cooperative } \\
\text { Group for the } \\
\text { Treatment of } \\
\text { Digestive } \\
\text { Tumours } \\
\text { (TTD); Roche } \\
\text { Phara AG }\end{array}$ & $\begin{array}{c}\text { July } \\
\text { 2012-November } \\
2018\end{array}$ & NP \\
\hline NCT01185509 & $\begin{array}{l}\text { A Phase II, Single Arm, Open Label Study to } \\
\text { Evaluate the Efficacy and Safety of } \\
\text { Trastuzumab and Vinorelbine in Advanced } \\
\text { Breast Cancer Patients with HER2 Negative } \\
\text { Primary Tumors and HER2 Positive } \\
\text { Circulating Tumor Cells }\end{array}$ & Int & Terminated & Phase 2 & 31 & $\begin{array}{c}\text { HER2 } \\
\text { negative } \\
\text { primary } \\
\text { breast } \\
\text { cancer }\end{array}$ & NP & $\begin{array}{l}\text { Evaluation of: ORR, CBR, } \\
\text { PFS, and CTC levels. } \\
\text { Description of CTC number } \\
\text { and CTC characteristics } \\
\text { before and after therapy, } \\
\text { and correlation of these } \\
\text { findings with response; safety } \\
\text { and tolerability of } \\
\text { trastuzumab and } \\
\text { vinorelbine treatment }\end{array}$ & $\begin{array}{l}\text { Dana-Farber } \\
\text { Cancer } \\
\text { Institute; } \\
\text { Brigham and } \\
\text { Women's } \\
\text { Hospital; Beth } \\
\text { Israel } \\
\text { Deaconess } \\
\text { Medical } \\
\text { Center; } \\
\text { Massachusetts } \\
\text { General } \\
\text { Hospital; } \\
\text { Genentech, } \\
\text { Inc. }\end{array}$ & $\begin{array}{l}\text { November } \\
\text { 2010-September } \\
2017\end{array}$ & NP \\
\hline
\end{tabular}


Table 1. Cont.

\begin{tabular}{|c|c|c|c|c|c|c|c|c|c|c|c|}
\hline Trial Number & Official Title & $\begin{array}{l}\text { Study } \\
\text { Type }\end{array}$ & Status & Phase & $\begin{array}{l}\text { Estimated/ } \\
\text { Actual } \\
\text { Enrollment }\end{array}$ & Disease & $\begin{array}{l}\text { CTC/Other } \\
\text { Biomarker } \\
\text { Measurem. } \\
\text { Method }\end{array}$ & $\begin{array}{c}\text { Outcome } \\
\text { Measures/Objectives }\end{array}$ & $\begin{array}{c}\text { Sponsor/ } \\
\text { Collaborators }\end{array}$ & $\begin{array}{c}\text { Start/ } \\
\text { Completion } \\
\text { Date }\end{array}$ & Publications \\
\hline NCT01456065 & $\begin{array}{l}\text { A Phase I, Open, Randomized, Study to } \\
\text { Investigate the Safety of Active } \\
\text { Immunotherapy with Fully Mature, } \\
\text { TERT-mRNA and Survivin-Peptide Double } \\
\text { Loaded Dendritic Cells (DCs) in Subjects } \\
\text { With Advanced Epithelial Ovarian Cancer, } \\
\text { Enrolled in the Study Within Twelve Weeks } \\
\text { After Completing Primary Therapy }\end{array}$ & Int & $\begin{array}{l}\text { Unknown } \\
\text { status }\end{array}$ & Phase 1 & 15 & $\begin{array}{l}\text { Ovarian } \\
\text { epithelial } \\
\text { cancer }\end{array}$ & NP & $\begin{array}{l}\text { Assessment of: incidence of } \\
\text { adverse events and clinical } \\
\text { relevant deviations from } \\
\text { laboratory parameters; } \\
\text { number of CTCs prior to } \\
\text { vaciination and at follow up; } \\
\text { number of autologous DCs } \\
\text { loaded with tumor-specific } \\
\text { antigens; time to progression } \\
\text { (CA-125 and CT); OS; } \\
\text { immune monitoring prior to } \\
\text { vaccination and during } \\
\text { treatment; }\end{array}$ & $\begin{array}{c}\text { Life Research } \\
\text { Technologies } \\
\text { GmbH }\end{array}$ & $\begin{array}{c}\text { September } \\
\text { 2010-April } \\
2013\end{array}$ & [256] \\
\hline NCT00879866 & $\begin{array}{l}\text { An Open-label, Phase Ib, Dose-escalation } \\
\text { Trial on the Safety, Tolerability, } \\
\text { Pharmacokinetics, Immunogenicity, } \\
\text { Biological Effects and Antitumor Activity of } \\
\text { EMD } 521873 \text { in Combination with Local } \\
\text { Irradiation (20 Gy) of Primary Tumors or } \\
\text { Metastases in Subjects With Non-small Cell } \\
\text { Lung Cancer Stage IIIb With Malignant } \\
\text { Pleural Effusion or Stage IV With Disease } \\
\text { Control (Partial Response or Stable Disease) } \\
\text { After Application of } 4 \text { Cycles of } \\
\text { Platinum-based, First-line Chemotherapy }\end{array}$ & Int & Completed & Phase 1 & 15 & $\begin{array}{l}\text { Non-small } \\
\text { cell lung } \\
\text { cancer }\end{array}$ & NP & $\begin{array}{l}\text { Assessment of: safety, } \\
\text { tolerability, and MTD (if } \\
\text { reached) with EMD } 518733 \\
\text { doses of up to } 0.45 \mathrm{mg} / \mathrm{kg} ; \mathrm{PK} \\
\text { of EMD } 521873 \text { in } \\
\text { combination with local tumor } \\
\text { irradiation; immunogenicity } \\
\text { of EMD } 521873 \text { in } \\
\text { combination with local tumor } \\
\text { irradiation by measuring the } \\
\text { induction of anti-EMD 521873 } \\
\text { Abs; best overall response; } \\
\text { changes in tumor marker } \\
\text { levels and CTC numbers after } \\
\text { treatment; best overall } \\
\text { response after second-line } \\
\text { therapy and duration of the } \\
\text { response; PFS and OS; } \\
\text { biological/immune responses } \\
\text { following treatment by } \\
\text { assessing changes in relevant } \\
\text { parameters including } \\
\text { leukocyte subset analysis and } \\
\text { molecular markers of } \\
\text { immune activation (e.g., } \\
\text { cytokines/chemokines, IL-2 } \\
\text { receptor, and noopterin) }\end{array}$ & Merck KGaA & $\begin{array}{c}\text { April } \\
\text { 2009-September } \\
2012\end{array}$ & [257] \\
\hline
\end{tabular}


Table 1. Cont.

\begin{tabular}{|c|c|c|c|c|c|c|c|c|c|c|c|}
\hline Trial Number & Official Title & $\begin{array}{l}\text { Study } \\
\text { Type }\end{array}$ & Status & Phase & $\begin{array}{l}\text { Estimated/ } \\
\text { Actual } \\
\text { Enrollment }\end{array}$ & Disease & $\begin{array}{l}\text { CTC/Other } \\
\text { Biomarker } \\
\text { Measurem. } \\
\text { Method }\end{array}$ & $\begin{array}{c}\text { Outcome } \\
\text { Measures/Objectives }\end{array}$ & $\begin{array}{c}\text { Sponsor/ } \\
\text { Collaborators }\end{array}$ & $\begin{array}{l}\text { Start/ } \\
\text { Completion } \\
\text { Date }\end{array}$ & Publications \\
\hline NCT00924092 & $\begin{array}{l}\text { Open Label Phase I Study to Evaluate the } \\
\text { Safety and Tolerability of Vaccine (GI-6207) } \\
\text { Consisting of Whole, Heat-Killed } \\
\text { Recombinant Saccharomyces Cerevisiae } \\
\text { Genetically Modified to Express CEA Protein } \\
\text { in Adults with Metastatic } \\
\text { CEA-Expressing Carcinoma }\end{array}$ & Int & Completed & Phase 1 & 25 & $\begin{array}{l}\text { Prostate, } \\
\text { breast, } \\
\text { lung, } \\
\text { colorectal, } \\
\text { head and } \\
\text { neck cancer }\end{array}$ & NP & $\begin{array}{l}\text { Determination of: safety and } \\
\text { tolerabilitity of escalating doses } \\
\text { of a heated-killed yeast-based } \\
\text { vaccine targeting tumors that } \\
\text { express CEA; evaluation of: } \\
\text { CD4 }{ }^{+} \text {and CD8 }{ }^{+} \text {cell } \\
\text { immunologic response; } \\
\text { humoral immune response to } \\
\text { yeast antigen; evidence of } \\
\text { clinical benefit such as PFS, } \\
\text { OR; decreases in CTCs; } \\
\text { tumor markers }\end{array}$ & $\begin{array}{l}\text { National } \\
\text { Cancer } \\
\text { Institute (NCI); } \\
\text { National } \\
\text { Institutes of } \\
\text { Health Clinical } \\
\text { Center (CC) }\end{array}$ & $\begin{array}{l}\text { March } \\
\text { 2009-August } \\
2012\end{array}$ & [258] \\
\hline NCT02048540 & $\begin{array}{l}\text { Phase } 2 \text { Study of Neoadjuvant Bevacizumab } \\
\text { Plus DOF Versus DOF in Local Advanced } \\
\text { Gastric Carcinoma and tts Association with } \\
\text { Circulating Tumor Cell }\end{array}$ & Int & Completed & $\begin{array}{l}\text { Phase } 1 \\
\text { and } \\
\text { phase } 2\end{array}$ & 86 & $\begin{array}{l}\text { Stage } \\
\text { IIIb-IIIc } \\
\text { gastric } \\
\text { carcinoma }\end{array}$ & NP & $\begin{array}{l}\text { Assessment of: R0 resection } \\
\text { rate; pCR rate; OS; DFS; ORR; } \\
\text { safety of perioperative } \\
\text { treatment and surgery; CTC } \\
\text { number change before and } \\
\text { after therapy }\end{array}$ & $\begin{array}{l}\text { Chinese PLA } \\
\text { General } \\
\text { Hospital }\end{array}$ & $\begin{array}{l}\text { February } \\
\text { 2009-December } \\
2013\end{array}$ & NP \\
\hline NCT00429247 & $\begin{array}{l}\text { A Pilot Randomized Phase II Study of } \\
\text { Adjuvant Administration of Trastuzumab } \\
\text { (HERCEPTIN) Versus Observation After the } \\
\text { Completion of Adjuvant Chemotherapy and } \\
\text { Radiotherapy in Patients with Stage P-III } \\
\text { Breast Cancer Who Have Detectable } \\
\text { Disseminated and/or Circulating Tumor } \\
\text { Cells (DTCs and/or CTCs) in the Bone } \\
\text { Marrow or/and the Peripheral Blood Before } \\
\text { or/and After the Completion of } \\
\text { Adjuvant Treatment }\end{array}$ & Int & Completed & Phase 2 & 75 & $\begin{array}{l}\text { Stage I-III } \\
\text { operable } \\
\text { breast } \\
\text { cancer }\end{array}$ & NP & $\begin{array}{l}\text { Comparison of disease-free } \\
\text { interval of patients with } \\
\text { early-stage breast cancer. } \\
\text { Evaluation of CK19 } \\
\text { mRNA-positive } \\
\text { CTC elimination }\end{array}$ & $\begin{array}{l}\text { University } \\
\text { Hospital of } \\
\text { Crete }\end{array}$ & $\begin{array}{l}\text { February } \\
\text { 2003-December } \\
2007\end{array}$ & $\mathrm{NP}$ \\
\hline
\end{tabular}

Abbreviations: androgen receptor (AR); cancer-associated macrophage-like cells (CAMLs); beads, emulsion, amplification, magnetics (BEAMing); cancer antigen (CA); cell-free circulating tumor deoxyribonecleic acid (ctDNA); circulating tumor cells (CTCs); clinical benefit rate (CBR); common terminology criteria for adverse events (CTCAE); complete response (CR); computed tomography (CT); dose-limiting toxicity (DLT); dendritic cell (DC); cytokine-induced killers (CIK); disease-free survival (DFS); docetaxel oxaliplatin 5-FU CF (DOF); epithelial-to-mesenchymal (EMT); event-free survival (EFS); flow cytometry (FCM); 5-FU/LV + irinotecan (FOLFIRI); interventional (int); immune-related complete response (irCR); immune-related partial response (irPR); immune-related RECIST (irRECIST); immunofluorescence (IF); inflammatory breast cancer (IBC); invasive disease-free survival (IDFS); isolation by size of tumor cells (ISET); maximum tolerated dose (MTD); metastatic breast cancer (mBC); metastatic colorectal cancer (mCRC); metastatic prostate cancer (mPCa); myeloid-derived suppressor cells (MDSCs); not provided (NP); observational (obs); overall response rate or objective response rate (ORR); overall survival (OS); partial response (PR); pathological complete remission (pCR) rate; pharmacokinetics (PK); positron emission tomography (PET); progressive disease (PD); progression-free survival (PFS); prostate specific antigen (PSA); radical (RO) resection; recurrence-free interval (RFI); response evaluation criteria in solid tumors (RECIST); response rate (RR); stable disease (SD); subtraction enrichment and immunostaining-fluorescence in situ hybridization (SE-iFISH); time to new metastases (TTNM); trastuzumab-emtansine (T-DM1); tumor-associated macrophage (TAM); tumor-infiltrating lymphocyte (TIL); ultrasound (US) 


\section{Conclusions}

By reviewing the main studies that directly or indirectly address the relationships between the immune system and CTCs we could observe that this is a new frontier of cancer research with a promising impact in the clinics.

However, concerning the feasibility of a prompt transfer from lab benchtop to patient bedside of the concepts discussed in these pages, it seems opportune to introduce two cautionary notes. First, the number of patients analyzed in the majority of the studies discussed here is very low; second, often, the experimental evidence obtained in in vitro or murine models has never been tested in clinical trials. It is clear that further studies in homogeneous groups of patients, who are undergoing the same treatment regimen and for whom a comprehensive characterization of their disease is available (including molecular markers and considering primary tumor, CTCs, and possible metastases), are necessary before we will be able to fully exploit the translational potential of CTC research in the oncoming era of cancer immunotherapy.

Finally, the recent molecular and computational genomic tools are gaining increasing attention thanks to the huge quantity of novel information they can provide to researchers. Over the next few years, we will probably witness a revolutionary progress in oncology and CTC-aided immunotherapy of tumors.

Author Contributions: R.Z. drew down the outline of topics; K.L. treated immune surveillance and escape; C.P. discussed biomarkers and immunotherapies; K.L., C.P., and R.Z. critically revised the selected scientific papers.

Funding: The work of K.L. is supported by Innovative Medicine Initiative Joint Undertaking [115749] CANCER-ID. The work of C.P. is supported by $5 \times 1000$ IOV-Translational Oncology: from benchtop to bedside [DGRV 2980/12 to R. Zamarchi]. The APC was funded by $5 \times 1000$ IOV-Translational Oncology: from benchtop to bedside [DGRV 2980/12 to R. Zamarchi].

Acknowledgments: The authors thank Elisabetta Rossi and Antonella Facchinetti (IOV-IRCCS, Padua, Italy) for critical reading of the manuscript and advice, as well as Christina Drace (IOV-IRCCS, Padua, Italy) for English editing. The concepts developed in this review were derived from the work performed at the CTC laboratory of IOV-IRCCS, Padua, Italy.

Conflicts of Interest: The authors declare no conflicts of interest.

\section{Abbreviations}

$\begin{array}{ll}\text { ACT } & \text { adoptive cell transfer } \\ \text { ADCC } & \text { antibody-dependent cellular cytotoxicity } \\ \text { APC } & \text { antigen-presenting cell } \\ \text { BC } & \text { breast cancer } \\ \text { CAML } & \text { cancer-associated macrophage-like cell } \\ \text { CAR } & \text { chimeric antigen receptor } \\ \text { CDC } & \text { complement-dependent cytotoxicity } \\ \text { CMC } & \text { circulating melanoma cell } \\ \text { CRC } & \text { colorectal cancer } \\ \text { CS } & \text { CellSearch } \\ \text { CSC } & \text { cancer stem cell } \\ \text { CTC } & \text { circulating tumor cell } \\ \text { CTL } & \text { cytotoxic T lymphocyte } \\ \text { CTM } & \text { circulating tumor microemboli } \\ \text { DC } & \text { dendritic cell } \\ \text { DCreg } & \text { regulatory dendritic cell } \\ \text { DFS } & \text { disease-free survival } \\ \text { ECM } & \text { extracellular matrix } \\ \text { EGFR } & \text { epidermal growth factor receptor } \\ \text { EMT } & \text { epithelial-to-mesenchymal transition } \\ \text { EPCAM } & \text { epithelial cell adhesion molecule } \\ \end{array}$




$\begin{array}{ll}\text { FAS } & \text { first apoptosis signal receptor } \\ \text { FDA } & \text { Food and Drug Administration } \\ \text { G-CSF } & \text { granulocyte-colony stimulating factor } \\ \text { HER2 } & \text { human epidermal growth factor receptor 2 } \\ \text { ILC2 } & \text { type 2 innate lymphoid cell } \\ \text { mAb } & \text { monoclonal antibody } \\ \text { MAM } & \text { metastasis-associated macrophage } \\ \text { MHC } & \text { major histocompatibility complex } \\ \text { MDSC } & \text { myeloid-derived suppressor cell } \\ \text { MET } & \text { mesenchymal-to-epithelial transition } \\ \text { MTF } & \text { macrophage-tumor cell fusion } \\ \text { NET } & \text { neutrophil extracellular trap } \\ \text { NK (cell) } & \text { natural killer (cell) } \\ \text { NSCLC } & \text { non-small cell lung cancer } \\ \text { OS } & \text { overall survival } \\ \text { PBMC } & \text { peripheral blood mononuclear cell } \\ \text { PD-L1 } & \text { programmed death-ligand 1 } \\ \text { PFS } & \text { progression-free survival } \\ \text { PMo } & \text { patrolling monocyte } \\ \text { RANKL } & \text { nuclear factor kappa-B ligand } \\ \text { TAM } & \text { tumor-associated macrophage } \\ \text { tBreg } & \text { tumor-evoked regulatory B cell } \\ \text { TCR } & \text { T cell receptor } \\ \text { TDSF } & \text { tumor-derived soluble factor } \\ \text { Th (cell) } & \text { T helper (cell) } \\ \text { TIL } & \text { tumor-infiltrating lymphocyte } \\ \text { TLR } & \text { Toll-like receptor } \\ \text { Treg } & \text { regulatory T lymphocyte } \\ \text { VCAM-1 } & \text { vascular cell adhesion molecule-1 } \\ & \end{array}$

\section{References}

1. Lambert, A.W.; Pattabiraman, D.R.; Weinberg, R.A. Emerging Biological Principles of Metastasis. Cell 2017, 168, 670-691. [CrossRef] [PubMed]

2. Braun, S.; Vogl, F.D.; Naume, B.; Janni, W.; Osborne, M.P.; Coombes, R.C.; Schlimok, G.; Diel, I.J.; Gerber, B.; Gebauer, G.; et al. A pooled analysis of bone marrow micrometastasis in breast cancer. N. Engl. J. Med. 2005, 353, 793-802. [CrossRef] [PubMed]

3. Morgan, T.M.; Lange, P.H.; Porter, M.P.; Lin, D.W.; Ellis, W.J.; Gallaher, I.S.; Vessella, R.L. Disseminated Tumor Cells in Prostate Cancer Patients after Radical Prostatectomy and without Evidence of Disease Predicts Biochemical Recurrence. Clin. Cancer Res. 2009, 15, 677-683. [CrossRef] [PubMed]

4. Hüsemann, Y.; Geigl, J.B.; Schubert, F.; Musiani, P.; Meyer, M.; Burghart, E.; Forni, G.; Eils, R.; Fehm, T.; Riethmüller, G.; et al. Systemic Spread Is an Early Step in Breast Cancer. Cancer Cell 2008, 13, 58-68. [CrossRef] [PubMed]

5. Bidard, F.C.; Peeters, D.J.; Fehm, T.; Nolé, F.; Gisbert-Criado, R.; Mavroudis, D.; Grisanti, S.; Generali, D.; Garcia-Saenz, J.A.; Stebbing, J.; et al. Clinical validity of circulating tumour cells in patients with metastatic breast cancer: A pooled analysis of individual patient data. Lancet Oncol. 2014, 15, 406-414. [CrossRef]

6. Amadori, A.; Rossi, E.; Zamarchi, R.; Carli, P.; Pastorelli, D.; Jirillo, A. Circulating and Disseminated Tumor Cells in the Clinical Management of Breast Cancer Patients: Unanswered Questions. Oncology 2009, 76, 375-386. [CrossRef] [PubMed]

7. Fidler, I.J. Metastasis: Quantitative analysis of distribution and fate of tumor emboli labeled with 125 I-5-iodo-2'-deoxyuridine. J. Natl. Cancer Inst. 1970, 45, 773-782. [PubMed]

8. Luzzi, K.J.; MacDonald, I.C.; Schmidt, E.E.; Kerkvliet, N.; Morris, V.L.; Chambers, A.F.; Groom, A.C. Multistep nature of metastatic inefficiency: Dormancy of solitary cells after successful extravasation and limited survival of early micrometastases. Am. J. Pathol. 1998, 153, 865-873. [CrossRef] 
9. Strilic, B.; Offermanns, S. Intravascular Survival and Extravasation of Tumor Cells. Cancer Cell 2017, 32, 282-293. [CrossRef] [PubMed]

10. Yu, M.; Bardia, A.; Wittner, B.S.; Stott, S.L.; Smas, M.E.; Ting, D.T.; Isakoff, S.J.; Ciciliano, J.C.; Wells, M.N.; Shah, A.M.; et al. Circulating Breast Tumor Cells Exhibit Dynamic Changes in Epithelial and Mesenchymal Composition. Science 2013, 339, 580-584. [CrossRef] [PubMed]

11. Kitamura, T.; Qian, B.-Z.; Pollard, J.W. Immune cell promotion of metastasis. Nat. Rev. Immunol. 2015, 15, 73-86. [CrossRef] [PubMed]

12. Mittal, D.; Gubin, M.M.; Schreiber, R.D.; Smyth, M.J. New insights into cancer immunoediting and its three component phases-Elimination, equilibrium and escape. Curr. Opin. Immunol. 2014, 27, 16-25. [CrossRef] [PubMed]

13. Kaplan, R.N.; Riba, R.D.; Zacharoulis, S.; Bramley, A.H.; Vincent, L.; Costa, C.; MacDonald, D.D.; Jin, D.K.; Shido, K.; Kerns, S.A.; et al. VEGFR1-positive haematopoietic bone marrow progenitors initiate the pre-metastatic niche. Nature 2005, 438, 820-827. [CrossRef] [PubMed]

14. Hiratsuka, S.; Watanabe, A.; Aburatani, H.; Maru, Y. Tumour-mediated upregulation of chemoattractants and recruitment of myeloid cells predetermines lung metastasis. Nat. Cell Biol. 2006, 8, 1369-1375. [CrossRef] [PubMed]

15. Luo, J.-L.; Maeda, S.; Hsu, L.-C.; Yagita, H.; Karin, M. Inhibition of NF- $\mathrm{kB}$ in cancer cells converts inflammation-induced tumor growth mediated by TNF $\alpha$ to TRAIL-mediated tumor regression. Cancer Cell 2004, 6, 297-305. [CrossRef] [PubMed]

16. Kim, S.; Takahashi, H.; Lin, W.-W.; Descargues, P.; Grivennikov, S.; Kim, Y.; Luo, J.-L.; Karin, M. Carcinoma-produced factors activate myeloid cells through TLR2 to stimulate metastasis. Nature 2009, 457, 102-106. [CrossRef] [PubMed]

17. Cabioglu, N.; Sahin, A.A.; Morandi, P.; Meric-Bernstam, F.; Islam, R.; Lin, H.Y.; Bucana, C.D.; Gonzalez-Angulo, A.M.; Hortobagyi, G.N.; Cristofanilli, M. Chemokine receptors in advanced breast cancer: Differential expression in metastatic disease sites with diagnostic and therapeutic implications. Ann. Oncol. 2009, 20, 1013-1019. [CrossRef] [PubMed]

18. Hensler, M.; Vančurová, I.; Becht, E.; Palata, O.; Strnad, P.; Tesařová, P.; Čabiňaková, M.; Švec, D.; Kubista, M.; Bartůňková, J.; et al. Gene expression profiling of circulating tumor cells and peripheral blood mononuclear cells from breast cancer patients. OncoImmunology 2015, 5, e1102827. [CrossRef] [PubMed]

19. Santos, M.F.; Mannam, V.K.R.; Craft, B.S.; Puneky, L.V.; Sheehan, N.T.; Lewis, R.E.; Cruse, J.M. Comparative analysis of innate immune system function in metastatic breast, colorectal, and prostate cancer patients with circulating tumor cells. Exp. Mol. Pathol. 2014, 96, 367-374. [CrossRef] [PubMed]

20. Hanna, N. Role of natural killer cells in control of cancer metastasis. Cancer Metastasis Rev. 1982, 1, 45-64. [CrossRef] [PubMed]

21. Brodbeck, T.; Nehmann, N.; Bethge, A.; Wedemann, G.; Schumacher, U. Perforin-dependent direct cytotoxicity in natural killer cells induces considerable knockdown of spontaneous lung metastases and computer modelling-proven tumor cell dormancy in a HT29 human colon cancer xenograft mouse model. Mol. Cancer 2014, 13, 244. [CrossRef] [PubMed]

22. López-Soto, A.; Gonzalez, S.; Smyth, M.J.; Galluzzi, L. Control of Metastasis by NK Cells. Cancer Cell 2017, 32, 135-154. [CrossRef] [PubMed]

23. Waldhauer, I.; Steinle, A. NK cells and cancer immunosurveillance. Oncogene 2008, 27, 5932-5943. [CrossRef] [PubMed]

24. Green, T.L.; Cruse, J.M.; Lewis, R.E. Circulating tumor cells (CTCs) from metastatic breast cancer patients linked to decreased immune function and response to treatment. Exp. Mol. Pathol. 2013, 95, 174-179. [CrossRef] [PubMed]

25. Pagès, F.; Galon, J.; Dieu-Nosjean, M.C.; Tartour, E.; Sautès-Fridman, C.; Fridman, W.H. Immune infiltration in human tumors: A prognostic factor that should not be ignored. Oncogene 2009, 29, 1093-1102. [CrossRef] [PubMed]

26. Gooden, M.J.M.; de Bock, G.H.; Leffers, N.; Daemen, T.; Nijman, H.W. The prognostic influence of tumour-infiltrating lymphocytes in cancer: A systematic review with meta-analysis. Br. J. Cancer 2011, 105, 93-103. [CrossRef] [PubMed]

27. De Giorgi, U.; Mego, M.; Scarpi, E.; Giuliano, M.; Giordano, A.; Reuben, J.M.; Valero, V.; Ueno, N.T.; Hortobagyi, G.N.; Cristofanilli, M. Relationship Between Lymphocytopenia and Circulating Tumor Cells as 
Prognostic Factors for Overall Survival in Metastatic Breast Cancer. Clin. Breast Cancer 2012, 12, $264-269$. [CrossRef] [PubMed]

28. Mego, M.; Gao, H.; Cohen, E.N.; Anfossi, S.; Giordano, A.; Sanda, T.; Fouad, T.M.; De Giorgi, U.; Giuliano, M.; Woodward, W.A.; et al. Circulating Tumor Cells (CTC) Are Associated with Defects in Adaptive Immunity in Patients with Inflammatory Breast Cancer. J. Cancer 2016, 7, 1095-1104. [CrossRef] [PubMed]

29. Ye, L.; Zhang, F.; Li, H.; Yang, L.; Lv, T.; Gu, W.; Song, Y. Circulating Tumor Cells Were Associated with the Number of T Lymphocyte Subsets and NK Cells in Peripheral Blood in Advanced Non-Small-Cell Lung Cancer. Dis. Mark. 2017, 2017, 5727815. [CrossRef] [PubMed]

30. Sun, W.-W.; Xu, Z.-H.; Lian, P.; Gao, B.-L.; Hu, J.-A. Characteristics of circulating tumor cells in organ metastases, prognosis, and T lymphocyte mediated immune response. OncoTargets Ther. 2017, 10, 2413-2424. [CrossRef] [PubMed]

31. Gruber, I.; Landenberger, N.; Staebler, A.; Hahn, M.; Wallwiener, D.; Fehm, T. Relationship between circulating tumor cells and peripheral T-cells in patients with primary breast cancer. Anticancer Res. 2013, 33, 2233-2238. [PubMed]

32. De Lafaille, M.A.C.; Lafaille, J.J. Natural and Adaptive Foxp3+ Regulatory T Cells: More of the Same or a Division of Labor? Immunity 2009, 30, 626-635. [CrossRef] [PubMed]

33. Dalotto-Moreno, T.; Croci, D.O.; Cerliani, J.P.; Martinez-Allo, V.C.; Dergan-Dylon, S.; Mendez-Huergo, S.P.; Stupirski, J.C.; Mazal, D.; Osinaga, E.; Toscano, M.A.; et al. Targeting Galectin-1 Overcomes Breast Cancer-Associated Immunosuppression and Prevents Metastatic Disease. Cancer Res. 2012, 73, 1107-1117. [CrossRef] [PubMed]

34. Jiang, H.; Gebhardt, C.; Umansky, L.; Beckhove, P.; Schulze, T.J.; Utikal, J.; Umansky, V. Elevated chronic inflammatory factors and myeloid-derived suppressor cells indicate poor prognosis in advanced melanoma patients. Int. J. Cancer 2015, 136, 2352-2360. [CrossRef] [PubMed]

35. Nakamura, R.; Sakakibara, M.; Nagashima, T.; Sangai, T.; Arai, M.; Fujimori, T.; Takano, S.; Shida, T.; Nakatani, Y.; Miyazaki, M. Accumulation of regulatory T cells in sentinel lymph nodes is a prognostic predictor in patients with node-negative breast cancer. Eur. J. Cancer 2009, 45, 2123-2131. [CrossRef] [PubMed]

36. Olkhanud, P.B.; Baatar, D.; Bodogai, M.; Hakim, F.; Gress, R.; Anderson, R.L.; Deng, J.; Xu, M.; Briest, S.; Biragyn, A. Breast Cancer Lung Metastasis Requires Expression of Chemokine Receptor CCR4 and Regulatory T Cells. Cancer Res. 2009, 69, 5996-6004. [CrossRef] [PubMed]

37. Smyth, M.J.; Teng, M.W.L.; Swann, J.; Kyparissoudis, K.; Godfrey, D.I.; Hayakawa, Y. CD4+CD25+ T Regulatory Cells Suppress NK Cell-Mediated Immunotherapy of Cancer. J. Immunol. 2006, 176, 1582-1587. [CrossRef] [PubMed]

38. Yang, P.; Li, Q.-J.; Feng, Y.; Zhang, Y.; Markowitz, G.J.; Ning, S.; Deng, Y.; Zhao, J.; Jiang, S.; Yuan, Y.; et al. TGF- $\beta$-miR-34a-CCL22 Signaling-Induced Treg Cell Recruitment Promotes Venous Metastases of HBV-Positive Hepatocellular Carcinoma. Cancer Cell 2012, 22, 291-303. [CrossRef] [PubMed]

39. Chopra, M.; Riedel, S.S.; Biehl, M.; Krieger, S.; von Krosigk, V.; Bäuerlein, C.A.; Brede, C.; Jordan Garrote, A.-L.; Kraus, S.; Schäfer, V.; et al. Tumor necrosis factor receptor 2-dependent homeostasis of regulatory T cells as a player in TNF-induced experimental metastasis. Carcinogenesis 2013, 34, 1296-1303. [CrossRef] [PubMed]

40. Stanzer, S.; Dandachi, N.; Balic, M.; Resel, M.; Samonigg, H.; Bauernhofer, T. Resistance to Apoptosis and Expansion of Regulatory T Cells in Relation to the Detection of Circulating Tumor Cells in Patients with Metastatic Epithelial Cancer. J. Clin. Immunol. 2007, 28, 107-114. [CrossRef] [PubMed]

41. Zhou, Y.; Wang, B.; Wu, J.; Zhang, C.; Zhou, Y.; Yang, X.; Zhou, J.; Guo, W.; Fan, J. Association of preoperative EpCAM Circulating Tumor Cells and peripheral Treg cell levels with early recurrence of hepatocellular carcinoma following radical hepatic resection. BMC Cancer 2016, 16, 506. [CrossRef] [PubMed]

42. Tan, W.; Zhang, W.; Strasner, A.; Grivennikov, S.; Cheng, J.Q.; Hoffman, R.M.; Karin, M. Tumour-infiltrating regulatory T cells stimulate mammary cancer metastasis through RANKL-RANK signalling. Nature 2011, 470, 548-553. [CrossRef] [PubMed]

43. Gray, E.S.; Reid, A.L.; Bowyer, S.; Calapre, L.; Siew, K.; Pearce, R.; Cowell, L.; Frank, M.H.; Millward, M.; Ziman, M. Circulating Melanoma Cell Subpopulations: Their Heterogeneity and Differential Responses to Treatment. J. Investig. Dermatol. 2015, 135, 2040-2048. [CrossRef] [PubMed] 
44. Coffelt, S.B.; Kersten, K.; Doornebal, C.W.; Weiden, J.; Vrijland, K.; Hau, C.-S.; Verstegen, N.J.M.; Ciampricotti, M.; Hawinkels, L.J.A.C.; Jonkers, J.; et al. IL-17-producing $\gamma \delta \mathrm{T}$ cells and neutrophils conspire to promote breast cancer metastasis. Nature 2015, 522, 345-348. [CrossRef] [PubMed]

45. Kersten, K.; Coffelt, S.B.; Hoogstraat, M.; Verstegen, N.J.M.; Vrijland, K.; Ciampricotti, M.; Doornebal, C.W.; Hau, C.-S.; Wellenstein, M.D.; Salvagno, C.; et al. Mammary tumor-derived CCL2 enhances pro-metastatic systemic inflammation through upregulation of IL1 $\beta$ in tumor-associated macrophages. OncoImmunology 2017, 6, e1334744. [CrossRef] [PubMed]

46. Novitskiy, S.V.; Pickup, M.W.; Gorska, A.E.; Owens, P.; Chytil, A.; Aakre, M.; Wu, H.; Shyr, Y.; Moses, H.L. TGF-Receptor II Loss Promotes Mammary Carcinoma Progression by Th17-Dependent Mechanisms. Cancer Discov. 2011, 1, 430-441. [CrossRef] [PubMed]

47. Tseng, J.Y.; Yang, C.Y.; Liang, S.C.; Liu, R.S.; Yang, S.H.; Lin, J.K.; Chen, Y.M.; Wu, Y.C.; Jiang, J.K.; Lin, C.H. Interleukin-17A Modulates Circulating Tumor Cells in Tumor Draining Vein of Colorectal Cancers and Affects Metastases. Clin. Cancer Res. 2014, 20, 2885-2897. [CrossRef] [PubMed]

48. Wei, L.E.I.; Wang, H.U.I.; Yang, F.E.N.; Ding, Q.I.; Zhao, J. Interleukin-17 potently increases non-small cell lung cancer growth. Mol. Med. Rep. 2016, 13, 1673-1680. [CrossRef] [PubMed]

49. Li, Q.; Han, Y.; Fei, G.; Guo, Z.; Ren, T.; Liu, Z. IL-17 promoted metastasis of non-small-cell lung cancer cells. Immunol. Lett. 2012, 148, 144-150. [CrossRef] [PubMed]

50. Pan, B.; Shen, J.; Cao, J.; Zhou, Y.; Shang, L.; Jin, S.; Cao, S.; Che, D.; Liu, F.; Yu, Y. Interleukin-17 promotes angiogenesis by stimulating VEGF production of cancer cells via the STAT3/GIV signaling pathway in non-small-cell lung cancer. Sci. Rep. 2015, 5, 16053. [CrossRef] [PubMed]

51. Wen, Z.; Liao, Q.; Zhao, J.; Hu, Y.; You, L.; Lu, Z.; Jia, C.; Wei, Y.; Zhao, Y. High Expression of Interleukin-22 and Its Receptor Predicts Poor Prognosis in Pancreatic Ductal Adenocarcinoma. Ann. Surg. Oncol. 2013, 21, 125-132. [CrossRef] [PubMed]

52. Monteiro, A.C.; Leal, A.C.; Goncalves-Silva, T.; Mercadante, A.C.; Kestelman, F.; Chaves, S.B.; Azevedo, R.B.; Monteiro, J.P.; Bonomo, A. T cells induce pre-metastatic osteolytic disease and help bone metastases establishment in a mouse model of metastatic breast cancer. PLoS ONE 2013, 8, e68171. [CrossRef] [PubMed]

53. Taranova, A.G.; Maldonado, D.; Vachon, C.M.; Jacobsen, E.A.; Abdala-Valencia, H.; McGarry, M.P.; Ochkur, S.I.; Protheroe, C.A.; Doyle, A.; Grant, C.S.; et al. Allergic Pulmonary Inflammation Promotes the Recruitment of Circulating Tumor Cells to the Lung. Cancer Res. 2008, 68, 8582-8589. [CrossRef] [PubMed]

54. Bodogai, M.; Moritoh, K.; Lee-Chang, C.; Hollander, C.M.; Sherman-Baust, C.A.; Wersto, R.P.; Araki, Y.; Miyoshi, I.; Yang, L.; Trinchieri, G.; et al. Immunosuppressive and Prometastatic Functions of Myeloid-Derived Suppressive Cells Rely upon Education from Tumor-Associated B Cells. Cancer Res. 2015, 75, 3456-3465. [CrossRef] [PubMed]

55. Gasteiger, G.; Fan, X.; Dikiy, S.; Lee, S.Y.; Rudensky, A.Y. Tissue residency of innate lymphoid cells in lymphoid and nonlymphoid organs. Science 2015, 350, 981-985. [CrossRef] [PubMed]

56. Saranchova, I.; Han, J.; Zaman, R.; Arora, H.; Huang, H.; Fenninger, F.; Choi, K.B.; Munro, L.; Pfeifer, C.G.; Welch, I.; et al. Type 2 Innate Lymphocytes Actuate Immunity Against Tumours and Limit Cancer Metastasis. Sci. Rep. 2018, 8, 2924. [CrossRef] [PubMed]

57. Shojaei, F.; Wu, X.; Qu, X.; Kowanetz, M.; Yu, L.; Tan, M.; Meng, Y.G.; Ferrara, N. G-CSF-initiated myeloid cell mobilization and angiogenesis mediate tumor refractoriness to anti-VEGF therapy in mouse models. Proc. Natl. Acad. Sci. USA 2009, 106, 6742-6747. [CrossRef] [PubMed]

58. Kowanetz, M.; Wu, X.; Lee, J.; Tan, M.; Hagenbeek, T.; Qu, X.; Yu, L.; Ross, J.; Korsisaari, N.; Cao, T.; et al. Granulocyte-colony stimulating factor promotes lung metastasis through mobilization of Ly6G+Ly6C+ granulocytes. Proc. Natl. Acad. Sci. USA 2010, 107, 21248-21255. [CrossRef] [PubMed]

59. Granot, Z.; Henke, E.; Comen, E.A.; King, T.A.; Norton, L.; Benezra, R. Tumor Entrained Neutrophils Inhibit Seeding in the Premetastatic Lung. Cancer Cell 2011, 20, 300-314. [CrossRef] [PubMed]

60. Coffelt, S.B.; Wellenstein, M.D.; de Visser, K.E. Neutrophils in cancer: Neutral no more. Nat. Rev. Cancer 2016, 16, 431-446. [CrossRef] [PubMed]

61. Bald, T.; Quast, T.; Landsberg, J.; Rogava, M.; Glodde, N.; Lopez-Ramos, D.; Kohlmeyer, J.; Riesenberg, S.; van den Boorn-Konijnenberg, D.; Hömig-Hölzel, C.; et al. Ultraviolet-radiation-induced inflammation promotes angiotropism and metastasis in melanoma. Nature 2014, 507, 109-113. [CrossRef] [PubMed] 
62. McDonald, B.; Spicer, J.; Giannais, B.; Fallavollita, L.; Brodt, P.; Ferri, L.E. Systemic inflammation increases cancer cell adhesion to hepatic sinusoids by neutrophil mediated mechanisms. Int. J. Cancer 2009, 125, 1298-1305. [CrossRef] [PubMed]

63. Spicer, J.D.; McDonald, B.; Cools-Lartigue, J.J.; Chow, S.C.; Giannias, B.; Kubes, P.; Ferri, L.E. Neutrophils Promote Liver Metastasis via Mac-1-Mediated Interactions with Circulating Tumor Cells. Cancer Res. 2012, 72, 3919-3927. [CrossRef] [PubMed]

64. Huh, S.J.; Liang, S.; Sharma, A.; Dong, C.; Robertson, G.P. Transiently Entrapped Circulating Tumor Cells Interact with Neutrophils to Facilitate Lung Metastasis Development. Cancer Res. 2010, 70, 6071-6082. [CrossRef] [PubMed]

65. Strell, C.; Lang, K.; Niggemann, B.; Zaenker, K.S.; Entschladen, F. Neutrophil granulocytes promote the migratory activity of MDA-MB-468 human breast carcinoma cells via ICAM-1. Exp. Cell Res. 2010, 316, 138-148. [CrossRef] [PubMed]

66. Cools-Lartigue, J.; Spicer, J.; McDonald, B.; Gowing, S.; Chow, S.; Giannias, B.; Bourdeau, F.; Kubes, P.; Ferri, L. Neutrophil extracellular traps sequester circulating tumor cells and promote metastasis. J. Clin. Investig. 2013, 123, 3446-3458. [CrossRef] [PubMed]

67. Tohme, S.; Yazdani, H.O.; Al-Khafaji, A.B.; Chidi, A.P.; Loughran, P.; Mowen, K.; Wang, Y.; Simmons, R.L.; Huang, H.; Tsung, A. Neutrophil Extracellular Traps Promote the Development and Progression of Liver Metastases after Surgical Stress. Cancer Res. 2016, 76, 1367-1380. [CrossRef] [PubMed]

68. Park, J.; Wysocki, R.W.; Amoozgar, Z.; Maiorino, L.; Fein, M.R.; Jorns, J.; Schott, A.F.; Kinugasa-Katayama, Y.; Lee, Y.; Won, N.H.; et al. Cancer cells induce metastasis-supporting neutrophil extracellular DNA traps. Sci. Transl. Med. 2016, 8, 361ra138. [CrossRef] [PubMed]

69. Demers, M.; Krause, D.S.; Schatzberg, D.; Martinod, K.; Voorhees, J.R.; Fuchs, T.A.; Scadden, D.T.; Wagner, D.D. Cancers predispose neutrophils to release extracellular DNA traps that contribute to cancer-associated thrombosis. Proc. Natl. Acad. Sci. USA 2012, 109, 13076-13081. [CrossRef] [PubMed]

70. Najmeh, S.; Cools-Lartigue, J.; Rayes, R.F.; Gowing, S.; Vourtzoumis, P.; Bourdeau, F.; Giannias, B.; Berube, J.; Rousseau, S.; Ferri, L.E.; et al. Neutrophil extracellular traps sequester circulating tumor cells via $\beta 1$-integrin mediated interactions. Int. J. Cancer 2017, 140, 2321-2330. [CrossRef] [PubMed]

71. Boone, B.A.; Orlichenko, L.; Schapiro, N.E.; Loughran, P.; Gianfrate, G.C.; Ellis, J.T.; Singhi, A.D.; Kang, R.; Tang, D.; Lotze, M.T.; et al. The receptor for advanced glycation end products (RAGE) enhances autophagy and neutrophil extracellular traps in pancreatic cancer. Cancer Gene Ther. 2015, 22, 326-334. [CrossRef] [PubMed]

72. Yang, C.; Sun, W.; Cui, W.; Li, X.; Yao, J.; Jia, X.; Li, C.; Wu, H.; Hu, Z.; Zou, X. Procoagulant role of neutrophil extracellular traps in patients with gastric cancer. Int. J. Clin. Exp. Pathol. 2015, 8, 14075-14086. [PubMed]

73. Auffray, C.; Fogg, D.; Garfa, M.; Elain, G.; Join-Lambert, O.; Kayal, S.; Sarnacki, S.; Cumano, A.; Lauvau, G.; Geissmann, F. Monitoring of Blood Vessels and Tissues by a Population of Monocytes with Patrolling Behavior. Science 2007, 317, 666-670. [CrossRef] [PubMed]

74. Hanna, R.N.; Cekic, C.; Sag, D.; Tacke, R.; Thomas, G.D.; Nowyhed, H.; Herrley, E.; Rasquinha, N.; McArdle, S.; Wu, R.; et al. Patrolling monocytes control tumor metastasis to the lung. Science 2015, 350, 985-990. [CrossRef] [PubMed]

75. Ostrand-Rosenberg, S.; Fenselau, C. Myeloid-Derived Suppressor Cells: Immune-Suppressive Cells That Impair Antitumor Immunity and Are Sculpted by Their Environment. J. Immunol. 2018, 200, 422-431. [CrossRef] [PubMed]

76. Huang, A.; Zhang, B.; Wang, B.; Zhang, F.; Fan, K.-X.; Guo, Y.-J. Increased CD14+HLA-DR-/low myeloid-derived suppressor cells correlate with extrathoracic metastasis and poor response to chemotherapy in non-small cell lung cancer patients. Cancer Immunology, Immunotherapy 2013, 62, 1439-1451. [CrossRef] [PubMed]

77. Diaz-Montero, C.M.; Salem, M.L.; Nishimura, M.I.; Garrett-Mayer, E.; Cole, D.J.; Montero, A.J. Increased circulating myeloid-derived suppressor cells correlate with clinical cancer stage, metastatic tumor burden, and doxorubicin-cyclophosphamide chemotherapy. Cancer Immunology, Immunotherapy 2008, 58, 49-59. [CrossRef] [PubMed]

78. Yu, J.; Du, W.; Yan, F.; Wang, Y.; Li, H.; Cao, S.; Yu, W.; Shen, C.; Liu, J.; Ren, X. Myeloid-Derived Suppressor Cells Suppress Antitumor Immune Responses through IDO Expression and Correlate with Lymph Node Metastasis in Patients with Breast Cancer. J. Immunol. 2013, 190, 3783-3797. [CrossRef] [PubMed] 
79. Arnoletti, J.P.; Zhu, X.; Almodovar, A.J.O.; Veldhuis, P.P.; Sause, R.; Griffith, E.; Corpus, G.; Chang, J.C.C.; Fanaian, N.; Litherland, S.A. Portal Venous Blood Circulation Supports Immunosuppressive Environment and Pancreatic Cancer Circulating Tumor Cell Activation. Pancreas 2017, 46, 116-123. [CrossRef] [PubMed]

80. Oh, K.; Lee, O.Y.; Shon, S.Y.; Nam, O.; Ryu, P.M.; Seo, M.W.; Lee, D.S. A mutual activation loop between breast cancer cells and myeloid-derived suppressor cells facilitates spontaneous metastasis through IL-6 trans-signaling in a murine model. Breast Cancer Res. 2013, 15, R79. [CrossRef] [PubMed]

81. Yang, L.; DeBusk, L.M.; Fukuda, K.; Fingleton, B.; Green-Jarvis, B.; Shyr, Y.; Matrisian, L.M.; Carbone, D.P.; Lin, P.C. Expansion of myeloid immune suppressor $\mathrm{Gr}+\mathrm{CD} 11 \mathrm{~b}+$ cells in tumor-bearing host directly promotes tumor angiogenesis. Cancer Cell 2004, 6, 409-421. [CrossRef] [PubMed]

82. Yang, L.; Huang, J.; Ren, X.; Gorska, A.E.; Chytil, A.; Aakre, M.; Carbone, D.P.; Matrisian, L.M.; Richmond, A.; Lin, P.C.; et al. Abrogation of TGF $\beta$ Signaling in Mammary Carcinomas Recruits Gr-1+CD11b+ Myeloid Cells that Promote Metastasis. Cancer Cell 2008, 13, 23-35. [CrossRef] [PubMed]

83. Yan, H.H.; Pickup, M.; Pang, Y.; Gorska, A.E.; Li, Z.; Chytil, A.; Geng, Y.; Gray, J.W.; Moses, H.L.; Yang, L. Gr-1+CD11b+ Myeloid Cells Tip the Balance of Immune Protection to Tumor Promotion in the Premetastatic Lung. Cancer Res. 2010, 70, 6139-6149. [CrossRef] [PubMed]

84. Toh, B.; Wang, X.; Keeble, J.; Sim, W.J.; Khoo, K.; Wong, W.C.; Kato, M.; Prevost-Blondel, A.; Thiery, J.P.; Abastado, J.P. Mesenchymal transition and dissemination of cancer cells is driven by myeloid-derived suppressor cells infiltrating the primary tumor. PLoS Biol. 2011, 9, e1001162. [CrossRef] [PubMed]

85. Ouzounova, M.; Lee, E.; Piranlioglu, R.; El Andaloussi, A.; Kolhe, R.; Demirci, M.F.; Marasco, D.; Asm, I.; Chadli, A.; Hassan, K.A.; et al. Monocytic and granulocytic myeloid derived suppressor cells differentially regulate spatiotemporal tumour plasticity during metastatic cascade. Nat. Commun. 2017, 8, 14979. [CrossRef] [PubMed]

86. Bayon, L.G.; Izquierdo, M.A.; Sirovich, I.; van Rooijen, N.; Beelen, R.H.; Meijer, S. Role of Kupffer cells in arresting circulating tumor cells and controlling metastatic growth in the liver. Hepatology 1996, 23, 1224-1231. [CrossRef] [PubMed]

87. Deneve, E.; Riethdorf, S.; Ramos, J.; Nocca, D.; Coffy, A.; Daures, J.P.; Maudelonde, T.; Fabre, J.M.; Pantel, K.; Alix-Panabieres, C. Capture of Viable Circulating Tumor Cells in the Liver of Colorectal Cancer Patients. Clin. Chem. 2013, 59, 1384-1392. [CrossRef] [PubMed]

88. Gül, N.; Babes, L.; Siegmund, K.; Korthouwer, R.; Bögels, M.; Braster, R.; Vidarsson, G.; ten Hagen, T.L.M.; Kubes, P.; van Egmond, M. Macrophages eliminate circulating tumor cells after monoclonal antibody therapy. J. Clin. Investig. 2014, 124, 812-823. [CrossRef] [PubMed]

89. Franklin, R.A.; Liao, W.; Sarkar, A.; Kim, M.V.; Bivona, M.R.; Liu, K.; Pamer, E.G.; Li, M.O. The cellular and molecular origin of tumor-associated macrophages. Science 2014, 344, 921-925. [CrossRef] [PubMed]

90. Sica, A.; Mantovani, A. Macrophage plasticity and polarization: In vivo veritas. J. Clin. Investig. 2012, 122, 787-795. [CrossRef] [PubMed]

91. Qian, B.-Z.; Pollard, J.W. Macrophage Diversity Enhances Tumor Progression and Metastasis. Cell 2010, 141, 39-51. [CrossRef] [PubMed]

92. Song, L.; Asgharzadeh, S.; Salo, J.; Engell, K.; Wu, H.-w.; Sposto, R.; Ara, T.; Silverman, A.M.; DeClerck, Y.A.; Seeger, R.C.; et al. V $\alpha 24$-invariant NKT cells mediate antitumor activity via killing of tumor-associated macrophages. J. Clin. Investig. 2009, 119, 1524-1536. [CrossRef] [PubMed]

93. Steidl, C.; Lee, T.; Shah, S.P.; Farinha, P.; Han, G.; Nayar, T.; Delaney, A.; Jones, S.J.; Iqbal, J.; Weisenburger, D.D.; et al. Tumor-associated macrophages and survival in classic Hodgkin's lymphoma. N. Engl. J. Med. 2010, 362, 875-885. [CrossRef] [PubMed]

94. Wyckoff, J.; Wang, W.; Lin, E.Y.; Wang, Y.; Pixley, F.; Stanley, E.R.; Graf, T.; Pollard, J.W.; Segall, J.; Condeelis, J. A paracrine loop between tumor cells and macrophages is required for tumor cell migration in mammary tumors. Cancer Res. 2004, 64, 7022-7029. [CrossRef] [PubMed]

95. Wyckoff, J.B.; Wang, Y.; Lin, E.Y.; Li, J.F.; Goswami, S.; Stanley, E.R.; Segall, J.E.; Pollard, J.W.; Condeelis, J. Direct Visualization of Macrophage-Assisted Tumor Cell Intravasation in Mammary Tumors. Cancer Res. 2007, 67, 2649-2656. [CrossRef] [PubMed]

96. Sangaletti, S.; Di Carlo, E.; Gariboldi, S.; Miotti, S.; Cappetti, B.; Parenza, M.; Rumio, C.; Brekken, R.A.; Chiodoni, C.; Colombo, M.P. Macrophage-Derived SPARC Bridges Tumor Cell-Extracellular Matrix Interactions toward Metastasis. Cancer Res. 2008, 68, 9050-9059. [CrossRef] [PubMed] 
97. Yang, M.; Chen, J.; Su, F.; Yu, B.; Lin, L.; Liu, Y.; Huang, J.D.; Song, E. Microvesicles secreted by macrophages shuttle invasion-potentiating microRNAs into breast cancer cells. Mol. Cancer 2011, 10, 117. [CrossRef] [PubMed]

98. Chen, J.; Yao, Y.; Gong, C.; Yu, F.; Su, S.; Chen, J.; Liu, B.; Deng, H.; Wang, F.; Lin, L.; et al. CCL18 from Tumor-Associated Macrophages Promotes Breast Cancer Metastasis via PITPNM3. Cancer Cell 2011, 19, 541-555. [CrossRef] [PubMed]

99. Liu, B.; Jia, Y.; Ma, J.; Wu, S.; Jiang, H.; Cao, Y.; Sun, X.; Yin, X.; Yan, S.; Shang, M.; et al. Tumor-associated macrophage-derived CCL20 enhances the growth and metastasis of pancreatic cancer. Acta Biochim. Biophys. Sin. 2016, 48, 1067-1074. [CrossRef] [PubMed]

100. Ören, B.; Urosevic, J.; Mertens, C.; Mora, J.; Guiu, M.; Gomis, R.R.; Weigert, A.; Schmid, T.; Grein, S.; Brüne, B.; et al. Tumour stroma-derived lipocalin-2 promotes breast cancer metastasis. J. Pathol. 2016, 239, $274-285$. [CrossRef] [PubMed]

101. Ho, M.Y.; Tang, S.J.; Chuang, M.J.; Cha, T.L.; Li, J.Y.; Sun, G.H.; Sun, K.H. TNF-Induces Epithelial-Mesenchymal Transition of Renal Cell Carcinoma Cells via a GSK3-Dependent Mechanism. Mol. Cancer Res. 2012, 10, 1109-1119. [CrossRef] [PubMed]

102. Fu, X.T.; Dai, Z.; Song, K.; Zhang, Z.J.; Zhou, Z.J.; Zhou, S.L.; Zhao, Y.M.; Xiao, Y.S.; Sun, Q.M.; Ding, Z.B.; et al. Macrophage-secreted IL-8 induces epithelial-mesenchymal transition in hepatocellular carcinoma cells by activating the JAK2/STAT3/Snail pathway. Int. J. Oncol. 2015, 46, 587-596. [CrossRef] [PubMed]

103. Lee, C.-H.; Liu, S.-Y.; Chou, K.-C.; Yeh, C.-T.; Shiah, S.-G.; Huang, R.-Y.; Cheng, J.-C.; Yen, C.-Y.; Shieh, Y.-S. Tumor-Associated Macrophages Promote Oral Cancer Progression Through Activation of the Axl Signaling Pathway. Ann. Surg. Oncol. 2013, 21, 1031-1037. [CrossRef] [PubMed]

104. Sullivan, N.J.; Sasser, A.K.; Axel, A.E.; Vesuna, F.; Raman, V.; Ramirez, N.; Oberyszyn, T.M.; Hall, B.M. Interleukin-6 induces an epithelial-mesenchymal transition phenotype in human breast cancer cells. Oncogene 2009, 28, 2940-2947. [CrossRef] [PubMed]

105. Kawata, M.; Koinuma, D.; Ogami, T.; Umezawa, K.; Iwata, C.; Watabe, T.; Miyazono, K. TGF- $\beta$-induced epithelial-mesenchymal transition of A549 lung adenocarcinoma cells is enhanced by pro-inflammatory cytokines derived from RAW 264.7 macrophage cells. J. Biochem. 2012, 151, 205-216. [CrossRef] [PubMed]

106. Fan, Q.-M.; Jing, Y.-Y.; Yu, G.-F.; Kou, X.-R.; Ye, F.; Gao, L.; Li, R.; Zhao, Q.-D.; Yang, Y.; Lu, Z.-H.; et al. Tumor-associated macrophages promote cancer stem cell-like properties via transforming growth factor-beta1-induced epithelial-mesenchymal transition in hepatocellular carcinoma. Cancer Lett. 2014, 352, 160-168. [CrossRef] [PubMed]

107. Roh-Johnson, M.; Bravo-Cordero, J.J.; Patsialou, A.; Sharma, V.P.; Guo, P.; Liu, H.; Hodgson, L.; Condeelis, J. Macrophage contact induces RhoA GTPase signaling to trigger tumor cell intravasation. Oncogene 2013, 33, 4203-4212. [CrossRef] [PubMed]

108. Pignatelli, J.; Bravo-Cordero, J.J.; Roh-Johnson, M.; Gandhi, S.J.; Wang, Y.; Chen, X.; Eddy, R.J.; Xue, A.; Singer, R.H.; Hodgson, L.; et al. Macrophage-dependent tumor cell transendothelial migration is mediated by Notch1/MenaINV-initiated invadopodium formation. Sci. Rep. 2016, 6, 37874. [CrossRef] [PubMed]

109. Hamilton, G.; Rath, B.; Klameth, L.; Hochmair, M.J. Small cell lung cancer: Recruitment of macrophages by circulating tumor cells. OncoImmunology 2015, 5, e1093277. [CrossRef] [PubMed]

110. Qian, B.-Z.; Li, J.; Zhang, H.; Kitamura, T.; Zhang, J.; Campion, L.R.; Kaiser, E.A.; Snyder, L.A.; Pollard, J.W. CCL2 recruits inflammatory monocytes to facilitate breast-tumour metastasis. Nature 2011, 475, 222-225. [CrossRef] [PubMed]

111. Zhao, L.; Lim, S.Y.; Gordon-Weeks, A.N.; Tapmeier, T.T.; Im, J.H.; Cao, Y.; Beech, J.; Allen, D.; Smart, S.; Muschel, R.J. Recruitment of a myeloid cell subset (CD11b/Gr1mid) via CCL2/CCR2 promotes the development of colorectal cancer liver metastasis. Hepatology 2013, 57, 829-839. [CrossRef] [PubMed]

112. Qian, B.; Deng, Y.; Im, J.H.; Muschel, R.J.; Zou, Y.; Li, J.; Lang, R.A.; Pollard, J.W. A distinct macrophage population mediates metastatic breast cancer cell extravasation, establishment and growth. PLOS ONE 2009, 4, e6562. [CrossRef] [PubMed]

113. Hiratsuka, S.; Nakamura, K.; Iwai, S.; Murakami, M.; Itoh, T.; Kijima, H.; Shipley, J.M.; Senior, R.M.; Shibuya, M. MMP9 induction by vascular endothelial growth factor receptor-1 is involved in lung-specific metastasis. Cancer Cell 2002, 2, 289-300. [CrossRef]

114. Gil-Bernabe, A.M.; Ferjancic, S.; Tlalka, M.; Zhao, L.; Allen, P.D.; Im, J.H.; Watson, K.; Hill, S.A.; Amirkhosravi, A.; Francis, J.L.; et al. Recruitment of monocytes/macrophages by tissue factor-mediated 
coagulation is essential for metastatic cell survival and premetastatic niche establishment in mice. Blood 2012, 119, 3164-3175. [CrossRef] [PubMed]

115. Headley, M.B.; Bins, A.; Nip, A.; Roberts, E.W.; Looney, M.R.; Gerard, A.; Krummel, M.F. Visualization of immediate immune responses to pioneer metastatic cells in the lung. Nature 2016, 531, 513-517. [CrossRef] [PubMed]

116. Kitamura, T.; Qian, B.-Z.; Soong, D.; Cassetta, L.; Noy, R.; Sugano, G.; Kato, Y.; Li, J.; Pollard, J.W. CCL2-induced chemokine cascade promotes breast cancer metastasis by enhancing retention of metastasis-associated macrophages. J. Exp. Med. 2015, 212, 1043-1059. [CrossRef] [PubMed]

117. Chen, Q.; Zhang, X.H.F.; Massagué, J. Macrophage Binding to Receptor VCAM-1 Transmits Survival Signals in Breast Cancer Cells that Invade the Lungs. Cancer Cell 2011, 20, 538-549. [CrossRef] [PubMed]

118. Sevenich, L.; Bowman, R.L.; Mason, S.D.; Quail, D.F.; Rapaport, F.; Elie, B.T.; Brogi, E.; Brastianos, P.K.; Hahn, W.C.; Holsinger, L.J.; et al. Analysis of tumour- and stroma-supplied proteolytic networks reveals a brain-metastasis-promoting role for cathepsin S. Nat. Cell Biol. 2014, 16, 876-888. [CrossRef] [PubMed]

119. Ma, Y.; Shurin, G.V.; Peiyuan, Z.; Shurin, M.R. Dendritic Cells in the Cancer Microenvironment. J. Cancer 2013, 4, 36-44. [CrossRef] [PubMed]

120. Tran Janco, J.M.; Lamichhane, P.; Karyampudi, L.; Knutson, K.L. Tumor-Infiltrating Dendritic Cells in Cancer Pathogenesis. J. Immunol. 2015, 194, 2985-2991. [CrossRef] [PubMed]

121. Miyagawa, S.; Soeda, J.; Takagi, S.; Miwa, S.; Ichikawa, E.; Noike, T. Prognostic significance of mature dendritic cells and factors associated with their accumulation in metastatic liver tumors from colorectal cancer. Hum. Pathol. 2004, 35, 1392-1396. [CrossRef] [PubMed]

122. Lijun, Z.; Xin, Z.; Danhua, S.; Xiaoping, L.; Jianliu, W.; Huilan, W.; Lihui, W. Tumor-Infiltrating Dendritic Cells May Be Used as Clinicopathologic Prognostic Factors in Endometrial Carcinoma. Int. J. Gynecol. Cancer 2012, 22, 836-841. [CrossRef] [PubMed]

123. Green, T.L.; Santos, M.F.; Ejaeidi, A.A.; Craft, B.S.; Lewis, R.E.; Cruse, J.M. Toll-like receptor (TLR) expression of immune system cells from metastatic breast cancer patients with circulating tumor cells. Exp. Mol. Pathol. 2014, 97, 44-48. [CrossRef] [PubMed]

124. Herber, D.L.; Cao, W.; Nefedova, Y.; Novitskiy, S.V.; Nagaraj, S.; Tyurin, V.A.; Corzo, A.; Cho, H.-I.; Celis, E.; Lennox, B.; et al. Lipid accumulation and dendritic cell dysfunction in cancer. Nat. Med. 2010, 16, 880-886. [CrossRef] [PubMed]

125. Mego, M.; Gao, H.; Cohen, E.N.; Anfossi, S.; Giordano, A.; Tin, S.; Fouad, T.M.; De Giorgi, U.; Giuliano, M.; Woodward, W.A.; et al. Circulating tumor cells (CTCs) are associated with abnormalities in peripheral blood dendritic cells in patients with inflammatory breast cancer. Oncotarget 2017, 8, 35656-35668. [CrossRef] [PubMed]

126. Kudo-Saito, C.; Shirako, H.; Ohike, M.; Tsukamoto, N.; Kawakami, Y. CCL2 is critical for immunosuppression to promote cancer metastasis. Clin. Exp. Metastasis 2012, 30, 393-405. [CrossRef] [PubMed]

127. Kenkel, J.A.; Tseng, W.W.; Davidson, M.G.; Tolentino, L.L.; Choi, O.; Bhattacharya, N.; Seeley, E.S.; Winer, D.A.; Reticker-Flynn, N.E.; Engleman, E.G. An Immunosuppressive Dendritic Cell Subset Accumulates at Secondary Sites and Promotes Metastasis in Pancreatic Cancer. Cancer Res. 2017, 77, 4158-4170. [CrossRef] [PubMed]

128. Shen, Y.; Guo, D.; Weng, L.; Wang, S.; Ma, Z.; Yang, Y.; Wang, P.; Wang, J.; Cai, Z. Tumor-derived exosomes educate dendritic cells to promote tumor metastasis via HSP72/HSP105-TLR2/TLR4 pathway. OncoImmunology 2017, 6, e1362527. [CrossRef] [PubMed]

129. Pryczynicz, A.; Cepowicz, D.; Zaręba, K.; Gryko, M.; Hołody-Zaręba, J.; Kędra, B.; Kemona, A.; Guzińska-Ustymowicz, K. Dysfunctions in the Mature Dendritic Cells Are Associated with the Presence of Metastases of Colorectal Cancer in the Surrounding Lymph Nodes. Gastroenterol. Res. Pract. 2016, 2016, 2405437. [CrossRef] [PubMed]

130. Sawant, A.; Hensel, J.A.; Chanda, D.; Harris, B.A.; Siegal, G.P.; Maheshwari, A.; Ponnazhagan, S. Depletion of Plasmacytoid Dendritic Cells Inhibits Tumor Growth and Prevents Bone Metastasis of Breast Cancer Cells. J. Immunol. 2012, 189, 4258-4265. [CrossRef] [PubMed]

131. Conrad, C.; Gregorio, J.; Wang, Y.H.; Ito, T.; Meller, S.; Hanabuchi, S.; Anderson, S.; Atkinson, N.; Ramirez, P.T.; Liu, Y.J.; et al. Plasmacytoid Dendritic Cells Promote Immunosuppression in Ovarian Cancer via ICOS Costimulation of Foxp3+ T-Regulatory Cells. Cancer Res. 2012, 72, 5240-5249. [CrossRef] [PubMed] 
132. Gerlini, G.; Urso, C.; Mariotti, G.; Di Gennaro, P.; Palli, D.; Brandani, P.; Salvadori, A.; Pimpinelli, N.; Reali, U.M.; Borgognoni, L. Plasmacytoid dendritic cells represent a major dendritic cell subset in sentinel lymph nodes of melanoma patients and accumulate in metastatic nodes. Clin. Immunol. 2007, 125, 184-193. [CrossRef] [PubMed]

133. Liu, W.; Zhao, J.; Li, Q.; Wang, Q.; Zhou, Y.; Tong, Z. Gastric cancer patients have elevated plasmacytoid and CD1c+ dendritic cells in the peripheral blood. Oncol. Lett. 2018, 15, 5087-5092. [CrossRef] [PubMed]

134. Küsters, B.; Kats, G.; Roodink, I.; Verrijp, K.; Wesseling, P.; Ruiter, D.J.; de Waal, R.M.W.; Leenders, W.P.J. Micronodular transformation as a novel mechanism of VEGF-A-induced metastasis. Oncogene 2007, 26, 5808-5815. [CrossRef] [PubMed]

135. Borsig, L.; Wong, R.; Hynes, R.O.; Varki, N.M.; Varki, A. Synergistic effects of L- and P-selectin in facilitating tumor metastasis can involve non-mucin ligands and implicate leukocytes as enhancers of metastasis. Proc. Natl. Acad. Sci. USA 2002, 99, 2193-2198. [CrossRef] [PubMed]

136. Duda, D.G.; Duyverman, A.M.; Kohno, M.; Snuderl, M.; Steller, E.J.; Fukumura, D.; Jain, R.K. Malignant cells facilitate lung metastasis by bringing their own soil. Proc. Natl. Acad. Sci. USA 2010, 107, 21677-21682. [CrossRef] [PubMed]

137. Jiang, X.; Wong, K.H.K.; Khankhel, A.H.; Zeinali, M.; Reategui, E.; Phillips, M.J.; Luo, X.; Aceto, N.; Fachin, F.; Hoang, A.N.; et al. Microfluidic isolation of platelet-covered circulating tumor cells. Lab Chip 2017, 17, 3498-3503. [CrossRef] [PubMed]

138. Adams, D.L.; Martin, S.S.; Alpaugh, R.K.; Charpentier, M.; Tsai, S.; Bergan, R.C.; Ogden, I.M.; Catalona, W.; Chumsri, S.; Tang, C.M.; et al. Circulating giant macrophages as a potential biomarker of solid tumors. Proc. Natl. Acad. Sci. USA 2014, 111, 3514-3519. [CrossRef] [PubMed]

139. Adams, D.L.; Adams, D.K.; Alpaugh, R.K.; Cristofanilli, M.; Martin, S.S.; Chumsri, S.; Tang, C.M.; Marks, J.R. Circulating Cancer-Associated Macrophage-Like Cells Differentiate Malignant Breast Cancer and Benign Breast Conditions. Cancer Epidemiol. Biomark. Prev. 2016, 25, 1037-1042. [CrossRef] [PubMed]

140. Clawson, G.A.; Matters, G.L.; Xin, P.; Imamura-Kawasawa, Y.; Du, Z.; Thiboutot, D.M.; Helm, K.F.; Neves, R.I.; Abraham, T. Macrophage-tumor cell fusions from peripheral blood of melanoma patients. PLoS ONE 2015, 10, e0134320. [CrossRef] [PubMed]

141. Adams, D.L.; Adams, D.K.; He, J.; Kalhor, N.; Zhang, M.; Xu, T.; Gao, H.; Reuben, J.M.; Qiao, Y.; Komaki, R.; et al. Sequential Tracking of PD-L1 Expression and RAD50 Induction in Circulating Tumor and Stromal Cells of Lung Cancer Patients Undergoing Radiotherapy. Clin. Cancer Res. 2017, 23, 5948-5958. [CrossRef] [PubMed]

142. Mu, Z.; Wang, C.; Ye, Z.; Rossi, G.; Sun, C.; Li, L.; Zhu, Z.; Yang, H.; Cristofanilli, M. Prognostic values of cancer associated macrophage-like cells (CAML) enumeration in metastatic breast cancer. Breast Cancer Res. Treat. 2017, 165, 733-741. [CrossRef] [PubMed]

143. Mohme, M.; Riethdorf, S.; Pantel, K. Circulating and disseminated tumour cells-Mechanisms of immune surveillance and escape. Nat. Rev. Clin. Oncol. 2016, 14, 155-167. [CrossRef] [PubMed]

144. Watson, N.F.S.; Ramage, J.M.; Madjd, Z.; Spendlove, I.; Ellis, I.O.; Scholefield, J.H.; Durrant, L.G. Immunosurveillance is active in colorectal cancer as downregulation but not complete loss of MHC class I expression correlates with a poor prognosis. Int. J. Cancer 2006, 118, 6-10. [CrossRef] [PubMed]

145. Placke, T.; Orgel, M.; Schaller, M.; Jung, G.; Rammensee, H.G.; Kopp, H.G.; Salih, H.R. Platelet-Derived MHC Class I Confers a Pseudonormal Phenotype to Cancer Cells That Subverts the Antitumor Reactivity of Natural Killer Immune Cells. Cancer Res. 2011, 72, 440-448. [CrossRef] [PubMed]

146. Wu, M.S.; Li, C.H.; Ruppert, J.G.; Chang, C.C. Cytokeratin 8-MHC class I interactions: A potential novel immune escape phenotype by a lymph node metastatic carcinoma cell line. Biochem. Biophys. Res. Commun. 2013, 441, 618-623. [CrossRef] [PubMed]

147. Mazel, M.; Jacot, W.; Pantel, K.; Bartkowiak, K.; Topart, D.; Cayrefourcq, L.; Rossille, D.; Maudelonde, T.; Fest, T.; Alix-Panabières, C. Frequent expression of PD-L1 on circulating breast cancer cells. Mol. Oncol. 2015, 9, 1773-1782. [CrossRef] [PubMed]

148. Nicolazzo, C.; Raimondi, C.; Mancini, M.; Caponnetto, S.; Gradilone, A.; Gandini, O.; Mastromartino, M.; del Bene, G.; Prete, A.; Longo, F.; et al. Monitoring PD-L1 positive circulating tumor cells in non-small cell lung cancer patients treated with the PD-1 inhibitor Nivolumab. Sci. Rep. 2016, 6, 31726. [CrossRef] [PubMed] 
149. Yue, C.; Jiang, Y.; Li, P.; Wang, Y.; Xue, J.; Li, N.; Li, D.; Wang, R.; Dang, Y.; Hu, Z.; et al. Dynamic change of PD-L1 expression on circulating tumor cells in advanced solid tumor patients undergoing PD-1 blockade therapy. OncoImmunology 2018, 7, e1438111. [CrossRef] [PubMed]

150. Kallergi, G.; Vetsika, E.-K.; Aggouraki, D.; Lagoudaki, E.; Koutsopoulos, A.; Koinis, F.; Katsarlinos, P.; Trypaki, M.; Messaritakis, I.; Stournaras, C.; et al. Evaluation of PD-L1/PD-1 on circulating tumor cells in patients with advanced non-small cell lung cancer. Ther. Adv. Med. Oncol. 2018, 10. [CrossRef] [PubMed]

151. Chao, M.P.; Tang, C.; Pachynski, R.K.; Chin, R.; Majeti, R.; Weissman, I.L. Extranodal dissemination of non-Hodgkin lymphoma requires CD47 and is inhibited by anti-CD47 antibody therapy. Blood 2011, 118, 4890-4901. [CrossRef] [PubMed]

152. Baccelli, I.; Schneeweiss, A.; Riethdorf, S.; Stenzinger, A.; Schillert, A.; Vogel, V.; Klein, C.; Saini, M.; Bäuerle, T.; Wallwiener, M.; et al. Identification of a population of blood circulating tumor cells from breast cancer patients that initiates metastasis in a xenograft assay. Nat. Biotechnol. 2013, 31, 539-544. [CrossRef] [PubMed]

153. Steinert, G.; Schölch, S.; Niemietz, T.; Iwata, N.; García, S.A.; Behrens, B.; Voigt, A.; Kloor, M.; Benner, A.; Bork, U.; et al. Immune Escape and Survival Mechanisms in Circulating Tumor Cells of Colorectal Cancer. Cancer Res. 2014, 74, 1694-1704. [CrossRef] [PubMed]

154. Hallermalm, K.; De Geer, A.; Kiessling, R.; Levitsky, V.; Levitskaya, J. Autocrine secretion of Fas ligand shields tumor cells from Fas-mediated killing by cytotoxic lymphocytes. Cancer Res. 2004, 64, 6775-6782. [CrossRef] [PubMed]

155. Hong, Y.; Fang, F.; Zhang, Q. Circulating tumor cell clusters: What we know and what we expect. Int. J. Oncol. 2016, 49, 2206-2216. [CrossRef] [PubMed]

156. Labelle, M.; Begum, S.; Hynes, R.O. Direct signaling between platelets and cancer cells induces an epithelial-mesenchymal-like transition and promotes metastasis. Cancer Cell 2011, 20, 576-590. [CrossRef] [PubMed]

157. Weber, M.R.; Zuka, M.; Lorger, M.; Tschan, M.; Torbett, B.E.; Zijlstra, A.; Quigley, J.P.; Staflin, K.; Eliceiri, B.P.; Krueger, J.S.; et al. Activated tumor cell integrin $\alpha \mathrm{v} \beta 3$ cooperates with platelets to promote extravasation and metastasis from the blood stream. Thromb. Res. 2016, 140, S27-S36. [CrossRef]

158. Nieswandt, B.; Hafner, M.; Echtenacher, B.; Mannel, D.N. Lysis of tumor cells by natural killer cells in mice is impeded by platelets. Cancer Res. 1999, 59, 1295-1300. [PubMed]

159. Sneath, R.J.; Mangham, D.C. The normal structure and function of CD44 and its role in neoplasia. Mol. Pathol. 1998, 51, 191-200. [CrossRef] [PubMed]

160. Borsig, L.; Wong, R.; Feramisco, J.; Nadeau, D.R.; Varki, N.M.; Varki, A. Heparin and cancer revisited: Mechanistic connections involving platelets, P-selectin, carcinoma mucins, and tumor metastasis. Proc. Natl. Acad. Sci. USA 2001, 98, 3352-3357. [CrossRef] [PubMed]

161. Gunthert, U.; Hofmann, M.; Rudy, W.; Reber, S.; Zoller, M.; Haussmann, I.; Matzku, S.; Wenzel, A.; Ponta, H.; Herrlich, P. A new variant of glycoprotein CD44 confers metastatic potential to rat carcinoma cells. Cell 1991, 65, 13-24. [CrossRef]

162. Katoh, S.; Goi, T.; Naruse, T.; Ueda, Y.; Kurebayashi, H.; Nakazawa, T.; Kimura, Y.; Hirono, Y.; Yamaguchi, A. Cancer stem cell marker in circulating tumor cells: Expression of CD44 variant exon 9 is strongly correlated to treatment refractoriness, recurrence and prognosis of human colorectal cancer. Anticancer Res. 2015, 35, 239-244. [PubMed]

163. Oldenborg, P.A.; Zheleznyak, A.; Fang, Y.F.; Lagenaur, C.F.; Gresham, H.D.; Lindberg, F.P. Role of CD47 as a marker of self on red blood cells. Science 2000, 288, 2051-2054. [CrossRef] [PubMed]

164. Gardai, S.J.; McPhillips, K.A.; Frasch, S.C.; Janssen, W.J.; Starefeldt, A.; Murphy-Ullrich, J.E.; Bratton, D.L.; Oldenborg, P.A.; Michalak, M.; Henson, P.M. Cell-surface calreticulin initiates clearance of viable or apoptotic cells through trans-activation of LRP on the phagocyte. Cell 2005, 123, 321-334. [CrossRef] [PubMed]

165. Keir, M.E.; Butte, M.J.; Freeman, G.J.; Sharpe, A.H. PD-1 and Its Ligands in Tolerance and Immunity. Ann. Rev. Immunol. 2008, 26, 677-704. [CrossRef] [PubMed]

166. Wang, X.; Teng, F.; Kong, L.; Yu, J. PD-L1 expression in human cancers and its association with clinical outcomes. OncoTargets Ther. 2016, 9, 5023-5039.

167. Anantharaman, A.; Friedlander, T.; Lu, D.; Krupa, R.; Premasekharan, G.; Hough, J.; Edwards, M.; Paz, R.; Lindquist, K.; Graf, R.; et al. Programmed death-ligand 1 (PD-L1) characterization of circulating tumor cells 
(CTCs) in muscle invasive and metastatic bladder cancer patients. BMC Cancer 2016, 16, 744. [CrossRef] [PubMed]

168. Guibert, N.; Delaunay, M.; Lusque, A.; Boubekeur, N.; Rouquette, I.; Clermont, E.; Mourlanette, J.; Gouin, S.; Dormoy, I.; Favre, G.; et al. PD-L1 expression in circulating tumor cells of advanced non-small cell lung cancer patients treated with nivolumab. Lung Cancer 2018, 120, 108-112. [CrossRef] [PubMed]

169. Dhar, M.; Wong, J.; Che, J.; Matsumoto, M.; Grogan, T.; Elashoff, D.; Garon, E.B.; Goldman, J.W.; Sollier Christen, E.; Di Carlo, D.; et al. Evaluation of PD-L1 expression on vortex-isolated circulating tumor cells in metastatic lung cancer. Sci. Rep. 2018, 8, 2592. [CrossRef] [PubMed]

170. Strati, A.; Koutsodontis, G.; Papaxoinis, G.; Angelidis, I.; Zavridou, M.; Economopoulou, P.; Kotsantis, I.; Avgeris, M.; Mazel, M.; Perisanidis, C.; et al. Prognostic significance of PD-L1 expression on circulating tumor cells in patients with head and neck squamous cell carcinoma. Ann. Oncol. 2017, 28, 1923-1933. [CrossRef] [PubMed]

171. Teo, J.; Mirenska, A.; Tan, M.; Lee, Y.; Oh, J.; Hong, L.Z.; Wnek, R.; Yap, Y.S.; Shih, S.J.; AA, S.B.; et al. A preliminary study for the assessment of PD-L1 and PD-L2 on circulating tumor cells by microfluidic-based chipcytometry. Future Sci. OA 2017, 3, FSO244. [CrossRef] [PubMed]

172. Ilié, M.; Szafer-Glusman, E.; Hofman, V.; Chamorey, E.; Lalvée, S.; Selva, E.; Leroy, S.; Marquette, C.H.; Kowanetz, M.; Hedge, P.; et al. Detection of PD-L1 in circulating tumor cells and white blood cells from patients with advanced non-small-cell lung cancer. Ann. Oncol. 2018, 29, 193-199. [CrossRef] [PubMed]

173. Schnell, U.; Cirulli, V.; Giepmans, B.N.G. EpCAM: Structure and function in health and disease. Biochim. Biophys. Acta (BBA) Biomembr. 2013, 1828, 1989-2001. [CrossRef] [PubMed]

174. Manicone, M.; Poggiana, C.; Facchinetti, A.; Zamarchi, R. Critical issues in the clinical application of liquid biopsy in non-small cell lung cancer. J. Thorac. Dis. 2017, 9, S1346-S1358. [CrossRef] [PubMed]

175. Parkinson, D.R.; Dracopoli, N.; Petty, B.G.; Compton, C.; Cristofanilli, M.; Deisseroth, A.; Hayes, D.F.; Kapke, G.; Kumar, P.; Lee, J.S.H.; et al. Considerations in the development of circulating tumor cell technology for clinical use. J. Transl. Med. 2012, 10, 138. [CrossRef] [PubMed]

176. van der Gun, B.T.F.; Melchers, L.J.; Ruiters, M.H.J.; de Leij, L.F.M.H.; McLaughlin, P.M.J.; Rots, M.G. EpCAM in carcinogenesis: The good, the bad or the ugly. Carcinogenesis 2010, 31, 1913-1921. [CrossRef] [PubMed]

177. Gorges, T.M.; Tinhofer, I.; Drosch, M.; Rose, L.; Zollner, T.M.; Krahn, T.; von Ahsen, O. Circulating tumour cells escape from EpCAM-based detection due to epithelial-to-mesenchymal transition. BMC Cancer 2012, 12, 178. [CrossRef] [PubMed]

178. Terry, S.; Savagner, P.; Ortiz-Cuaran, S.; Mahjoubi, L.; Saintigny, P.; Thiery, J.-P.; Chouaib, S. New insights into the role of EMT in tumor immune escape. Mol. Oncol. 2017, 11, 824-846. [CrossRef] [PubMed]

179. Akalay, I.; Janji, B.; Hasmim, M.; Noman, M.Z.; Andre, F.; De Cremoux, P.; Bertheau, P.; Badoual, C.; Vielh, P.; Larsen, A.K.; et al. Epithelial-to-Mesenchymal Transition and Autophagy Induction in Breast Carcinoma Promote Escape from T-cell-Mediated Lysis. Cancer Res. 2013, 73, 2418-2427. [CrossRef] [PubMed]

180. Satelli, A.; Mitra, A.; Brownlee, Z.; Xia, X.; Bellister, S.; Overman, M.J.; Kopetz, S.; Ellis, L.M.; Meng, Q.H.; $\mathrm{Li}, \mathrm{S}$. Epithelial-mesenchymal transitioned circulating tumor cells capture for detecting tumor progression. Clin. Cancer Res. 2015, 21, 899-906. [CrossRef] [PubMed]

181. Lampignano, R.; Schneck, H.; Neumann, M.; Fehm, T.; Neubauer, H. Enrichment, Isolation and Molecular Characterization of EpCAM-Negative Circulating Tumor Cells. Adv. Exp. Med. Biol. 2017, 994, 181-203. [PubMed]

182. Papaioannou, N.E.; Beniata, O.V.; Vitsos, P.; Tsitsilonis, O.; Samara, P. Harnessing the immune system to improve cancer therapy. Ann. Transl. Med. 2016, 4, 261. [CrossRef] [PubMed]

183. Madic, J.; Kiialainen, A.; Bidard, F.C.; Birzele, F.; Ramey, G.; Leroy, Q.; Rio Frio, T.; Vaucher, I.; Raynal, V.; Bernard, V.; et al. Circulating tumor DNA and circulating tumor cells in metastatic triple negative breast cancer patients. Int. J. Cancer 2015, 136, 2158-2165. [CrossRef] [PubMed]

184. Chiavenna, S.M.; Jaworski, J.P.; Vendrell, A. State of the art in anti-cancer mAbs. J. Biomed. Sci. 2017, 24, 15. [CrossRef] [PubMed]

185. Vallera, D.A.; Zhang, B.; Gleason, M.K.; Oh, S.; Weiner, L.M.; Kaufman, D.S.; McCullar, V.; Miller, J.S.; Verneris, M.R. Heterodimeric bispecific single-chain variable-fragment antibodies against EpCAM and CD16 induce effective antibody-dependent cellular cytotoxicity against human carcinoma cells. Cancer Biother. Radiopharm. 2013, 28, 274-282. [CrossRef] [PubMed] 
186. Prang, N.; Preithner, S.; Brischwein, K.; Goster, P.; Woppel, A.; Muller, J.; Steiger, C.; Peters, M.; Baeuerle, P.A.; da Silva, A.J. Cellular and complement-dependent cytotoxicity of Ep-CAM-specific monoclonal antibody MT201 against breast cancer cell lines. Br. J. Cancer 2005, 92, 342-349. [CrossRef] [PubMed]

187. Scaltriti, M.; Baselga, J. The epidermal growth factor receptor pathway: A model for targeted therapy. Clin. Cancer Res. 2006, 12, 5268-5272. [CrossRef] [PubMed]

188. Salomon, D.S.; Brandt, R.; Ciardiello, F.; Normanno, N. Epidermal growth factor-related peptides and their receptors in human malignancies. Crit. Rev. Oncol. Hematol. 1995, 19, 183-232. [CrossRef]

189. Payne, R.E.; Yague, E.; Slade, M.J.; Apostolopoulos, C.; Jiao, L.R.; Ward, B.; Coombes, R.C.; Stebbing, J. Measurements of EGFR expression on circulating tumor cells are reproducible over time in metastatic breast cancer patients. Pharmacogenomics 2009, 10, 51-57. [CrossRef] [PubMed]

190. Punnoose, E.A.; Atwal, S.K.; Spoerke, J.M.; Savage, H.; Pandita, A.; Yeh, R.F.; Pirzkall, A.; Fine, B.M.; Amler, L.C.; Chen, D.S.; et al. Molecular biomarker analyses using circulating tumor cells. PLoS ONE 2010, 5, e12517. [CrossRef] [PubMed]

191. Shaffer, D.R.; Leversha, M.A.; Danila, D.C.; Lin, O.; Gonzalez-Espinoza, R.; Gu, B.; Anand, A.; Smith, K.; Maslak, P.; Doyle, G.V.; et al. Circulating Tumor Cell Analysis in Patients with Progressive Castration-Resistant Prostate Cancer. Clin. Cancer Res. 2007, 13, 2023-2029. [CrossRef] [PubMed]

192. Gorges, T.M.; Stein, A.; Quidde, J.; Hauch, S.; Rock, K.; Riethdorf, S.; Joosse, S.A.; Pantel, K. Improved Detection of Circulating Tumor Cells in Metastatic Colorectal Cancer by the Combination of the CellSearch(R) System and the AdnaTest(R). PLoS ONE 2016, 11, e0155126. [CrossRef] [PubMed]

193. Gasch, C.; Bauernhofer, T.; Pichler, M.; Langer-Freitag, S.; Reeh, M.; Seifert, A.M.; Mauermann, O.; Izbicki, J.R.; Pantel, K.; Riethdorf, S. Heterogeneity of Epidermal Growth Factor Receptor Status and Mutations of KRAS/PIK3CA in Circulating Tumor Cells of Patients with Colorectal Cancer. Clin. Chem. 2012, 59, 252-260. [CrossRef] [PubMed]

194. Musella, V.; Pietrantonio, F.; Di Buduo, E.; Iacovelli, R.; Martinetti, A.; Sottotetti, E.; Bossi, I.; Maggi, C.; Di Bartolomeo, M.; de Braud, F.; et al. Circulating tumor cells as a longitudinal biomarker in patients with advanced chemorefractory, RAS-BRAFwild-type colorectal cancer receiving cetuximab or panitumumab. Int. J. Cancer 2015, 137, 1467-1474. [CrossRef] [PubMed]

195. Kuboki, Y.; Matsusaka, S.; Minowa, S.; Shibata, H.; Suenaga, M.; Shinozaki, E.; Mizunuma, N.; Ueno, M.; Yamaguchi, T.; Hatake, K. Circulating tumor cell (CTC) count and epithelial growth factor receptor expression on CTCs as biomarkers for cetuximab efficacy in advanced colorectal cancer. Anticancer Res. 2013, 33, 3905-3910. [PubMed]

196. Slamon, D.J.; Clark, G.M.; Wong, S.G.; Levin, W.J.; Ullrich, A.; McGuire, W.L. Human breast cancer: Correlation of relapse and survival with amplification of the HER-2/neu oncogene. Science 1987, 235, 177-182. [CrossRef] [PubMed]

197. Meng, S.; Tripathy, D.; Shete, S.; Ashfaq, R.; Haley, B.; Perkins, S.; Beitsch, P.; Khan, A.; Euhus, D.; Osborne, C.; et al. HER-2 gene amplification can be acquired as breast cancer progresses. Proc. Natl. Acad. Sci. USA 2004, 101, 9393-9398. [CrossRef] [PubMed]

198. Fehm, T.; Muller, V.; Aktas, B.; Janni, W.; Schneeweiss, A.; Stickeler, E.; Lattrich, C.; Lohberg, C.R.; Solomayer, E.; Rack, B.; et al. HER2 status of circulating tumor cells in patients with metastatic breast cancer: A prospective, multicenter trial. Breast Cancer Res. Treat. 2010, 124, 403-412. [CrossRef] [PubMed]

199. Pestrin, M.; Bessi, S.; Galardi, F.; Truglia, M.; Biggeri, A.; Biagioni, C.; Cappadona, S.; Biganzoli, L.; Giannini, A.; Di Leo, A. Correlation of HER2 status between primary tumors and corresponding circulating tumor cells in advanced breast cancer patients. Breast Cancer Res. Treat. 2009, 118, 523-530. [CrossRef] [PubMed]

200. Munzone, E.; Nolé, F.; Goldhirsch, A.; Botteri, E.; Esposito, A.; Zorzino, L.; Curigliano, G.; Minchella, I.; Adamoli, L.; Cassatella, M.C.; et al. Changes of HER2 Status in Circulating Tumor Cells Compared With the Primary Tumor During Treatment for Advanced Breast Cancer. Clin. Breast Cancer 2010, 10, 392-397. [CrossRef] [PubMed]

201. Ignatiadis, M.; Rothe, F.; Chaboteaux, C.; Durbecq, V.; Rouas, G.; Criscitiello, C.; Metallo, J.; Kheddoumi, N.; Singhal, S.K.; Michiels, S.; et al. HER2-positive circulating tumor cells in breast cancer. PLoS ONE 2011, 6, e15624. [CrossRef] [PubMed] 
202. Zhang, S.; Li, L.; Wang, T.; Bian, L.; Hu, H.; Xu, C.; Liu, B.; Liu, Y.; Cristofanilli, M.; Jiang, Z. Real-time HER2 status detected on circulating tumor cells predicts different outcomes of anti-HER2 therapy in histologically HER2-positive metastatic breast cancer patients. BMC Cancer 2016, 16, 526. [CrossRef] [PubMed]

203. D'Oronzo, S.; Brown, J.; Coleman, R. The role of biomarkers in the management of bone-homing malignancies. J. Bone Oncol. 2017, 9, 1-9. [CrossRef] [PubMed]

204. Jones, D.H.; Nakashima, T.; Sanchez, O.H.; Kozieradzki, I.; Komarova, S.V.; Sarosi, I.; Morony, S.; Rubin, E.; Sarao, R.; Hojilla, C.V.; et al. Regulation of cancer cell migration and bone metastasis by RANKL. Nature 2006, 440, 692-696. [CrossRef] [PubMed]

205. Santini, D.; Schiavon, G.; Vincenzi, B.; Gaeta, L.; Pantano, F.; Russo, A.; Ortega, C.; Porta, C.; Galluzzo, S.; Armento, G.; et al. Receptor activator of NF-kB (RANK) expression in primary tumors associates with bone metastasis occurrence in breast cancer patients. PLoS ONE 2011, 6, e19234. [CrossRef] [PubMed]

206. Schieferdecker, A.; Voigt, M.; Riecken, K.; Braig, F.; Schinke, T.; Loges, S.; Bokemeyer, C.; Fehse, B.; Binder, M. Denosumab mimics the natural decoy receptor osteoprotegerin by interacting with its major binding site on RANKL. Oncotarget 2014, 5, 6647-6653. [CrossRef] [PubMed]

207. Buchbinder, E.I.; Desai, A. CTLA-4 and PD-1 Pathways. Am. J. Clin. Oncol. 2016, 39, 98-106. [CrossRef] [PubMed]

208. Linsley, P.S.; Bradshaw, J.; Greene, J.; Peach, R.; Bennett, K.L.; Mittler, R.S. Intracellular trafficking of CTLA-4 and focal localization towards sites of TCR engagement. Immunity 1996, 4, 535-543. [CrossRef]

209. Krummel, M.F.; Allison, J.P. CD28 and CTLA-4 have opposing effects on the response of T cells to stimulation. J. Exp. Med. 1995, 182, 459-465. [CrossRef] [PubMed]

210. Guinan, E.C.; Gribben, J.G.; Boussiotis, V.A.; Freeman, G.J.; Nadler, L.M. Pivotal role of the B7:CD28 pathway in transplantation tolerance and tumor immunity. Blood 1994, 84, 3261-3282. [PubMed]

211. Tarhini, A.; Lo, E.; Minor, D.R. Releasing the brake on the immune system: Ipilimumab in melanoma and other tumors. Cancer Biother. Radiopharm. 2010, 25, 601-613. [CrossRef] [PubMed]

212. Martens, A.; Wistuba-Hamprecht, K.; Yuan, J.; Postow, M.A.; Wong, P.; Capone, M.; Madonna, G.; Khammari, A.; Schilling, B.; Sucker, A.; et al. Increases in Absolute Lymphocytes and Circulating CD4+ and CD8+ T Cells Are Associated with Positive Clinical Outcome of Melanoma Patients Treated with Ipilimumab. Clin. Cancer Res. 2016, 22, 4848-4858. [CrossRef] [PubMed]

213. Damuzzo, V.; Solito, S.; Pinton, L.; Carrozzo, E.; Valpione, S.; Pigozzo, J.; Arboretti Giancristofaro, R.; Chiarion-Sileni, V.; Mandruzzato, S. Clinical implication of tumor-associated and immunological parameters in melanoma patients treated with ipilimumab. OncoImmunology 2016, 5, e1249559. [CrossRef] [PubMed]

214. Jamal, R.; Lapointe, R.; Cocolakis, E.; Thébault, P.; Kazemi, S.; Friedmann, J.E.; Dionne, J.; Cailhier, J.-F.; Bélanger, K.; Ayoub, J.-P.; et al. Peripheral and local predictive immune signatures identified in a phase II trial of ipilimumab with carboplatin/paclitaxel in unresectable stage III or stage IV melanoma. J. ImmunoTher. Cancer 2017, 5, 83. [CrossRef] [PubMed]

215. Chatenoud, L.; Tarhini, A.A.; Edington, H.; Butterfield, L.H.; Lin, Y.; Shuai, Y.; Tawbi, H.; Sander, C.; Yin, Y.; Holtzman, M.; et al. Immune Monitoring of the Circulation and the Tumor Microenvironment in Patients with Regionally Advanced Melanoma Receiving Neoadjuvant Ipilimumab. PLoS ONE 2014, 9, e87705.

216. Khoja, L.; Lorigan, P.; Zhou, C.; Lancashire, M.; Booth, J.; Cummings, J.; Califano, R.; Clack, G.; Hughes, A.; Dive, C. Biomarker Utility of Circulating Tumor Cells in Metastatic Cutaneous Melanoma. J. Investig. Dermatol. 2013, 133, 1582-1590. [CrossRef] [PubMed]

217. Klinac, D.; Gray, E.S.; Freeman, J.B.; Reid, A.; Bowyer, S.; Millward, M.; Ziman, M. Monitoring changes in circulating tumour cells as a prognostic indicator of overall survival and treatment response in patients with metastatic melanoma. BMC Cancer 2014, 14, 423. [CrossRef] [PubMed]

218. Hong, X.; Sullivan, R.J.; Kalinich, M.; Kwan, T.T.; Giobbie-Hurder, A.; Pan, S.; LiCausi, J.A.; Milner, J.D.; Nieman, L.T.; Wittner, B.S.; et al. Molecular signatures of circulating melanoma cells for monitoring early response to immune checkpoint therapy. Proc. Natl. Acad. Sci. USA 2018, 115, 2467-2472. [CrossRef] [PubMed]

219. Alsaab, H.O.; Sau, S.; Alzhrani, R.; Tatiparti, K.; Bhise, K.; Kashaw, S.K.; Iyer, A.K. PD-1 and PD-L1 Checkpoint Signaling Inhibition for Cancer Immunotherapy: Mechanism, Combinations, and Clinical Outcome. Front. Pharmacol. 2017, 8, 561. [CrossRef] [PubMed]

220. Patel, S.P.; Kurzrock, R. PD-L1 Expression as a Predictive Biomarker in Cancer Immunotherapy. Mol. Cancer Ther. 2015, 14, 847-856. [CrossRef] [PubMed] 
221. Meng, X.; Huang, Z.; Teng, F.; Xing, L.; Yu, J. Predictive biomarkers in PD-1/PD-L1 checkpoint blockade immunotherapy. Cancer Treat. Rev. 2015, 41, 868-876. [CrossRef] [PubMed]

222. Callea, M.; Albiges, L.; Gupta, M.; Cheng, S.C.; Genega, E.M.; Fay, A.P.; Song, J.; Carvo, I.; Bhatt, R.S.; Atkins, M.B.; et al. Differential Expression of PD-L1 between Primary and Metastatic Sites in Clear-Cell Renal Cell Carcinoma. Cancer Immunol. Res. 2015, 3, 1158-1164. [CrossRef] [PubMed]

223. Rosenberg, S.A.; Restifo, N.P.; Yang, J.C.; Morgan, R.A.; Dudley, M.E. Adoptive cell transfer: A clinical path to effective cancer immunotherapy. Nat. Rev. Cancer 2008, 8, 299-308. [CrossRef] [PubMed]

224. Rosenberg, S.A.; Packard, B.S.; Aebersold, P.M.; Solomon, D.; Topalian, S.L.; Toy, S.T.; Simon, P.; Lotze, M.T.; Yang, J.C.; Seipp, C.A.; et al. Use of tumor-infiltrating lymphocytes and interleukin-2 in the immunotherapy of patients with metastatic melanoma. A preliminary report. N. Engl. J. Med. 1988, 319, 1676-1680. [CrossRef] [PubMed]

225. Rosenberg, S.A.; Yang, J.C.; Sherry, R.M.; Kammula, U.S.; Hughes, M.S.; Phan, G.Q.; Citrin, D.E.; Restifo, N.P.; Robbins, P.F.; Wunderlich, J.R.; et al. Durable Complete Responses in Heavily Pretreated Patients with Metastatic Melanoma Using T-Cell Transfer Immunotherapy. Clin. Cancer Res. 2011, 17, 4550-4557. [CrossRef] [PubMed]

226. Fousek, K.; Ahmed, N. The Evolution of T-cell Therapies for Solid Malignancies. Clin. Cancer Res. 2015, 21, 3384-3392. [CrossRef] [PubMed]

227. Liang, S.; Xu, K.; Niu, L.; Wang, X.; Liang, Y.; Zhang, M.; Chen, J.; Lin, M. Comparison of autogeneic and allogeneic natural killer cells immunotherapy on the clinical outcome of recurrent breast cancer. OncoTargets Ther. 2017, 10, 4273-4281. [CrossRef] [PubMed]

228. Lin, M.; Liang, S.-Z.; Shi, J.; Niu, L.-Z.; Chen, J.-B.; Zhang, M.-J.; Xu, K.-C. Circulating tumor cell as a biomarker for evaluating allogenic NK cell immunotherapy on stage IV non-small cell lung cancer. Immunol. Lett. 2017, 191, 10-15. [CrossRef] [PubMed]

229. Qin, Z.; Chen, J.; Zeng, J.; Niu, L.; Xie, S.; Wang, X.; Liang, Y.; Wu, Z.; Zhang, M. Effect of NK cell immunotherapy on immune function in patients with hepatic carcinoma: A preliminary clinical study. Cancer Biol. Ther. 2017, 18, 323-330. [CrossRef] [PubMed]

230. Guo, C.; Manjili, M.H.; Subjeck, J.R.; Sarkar, D.; Fisher, P.B.; Wang, X.Y. Therapeutic cancer vaccines: Past, present, and future. Adv. Cancer Res. 2013, 119, 421-475. [PubMed]

231. Romero, P.; Banchereau, J.; Bhardwaj, N.; Cockett, M.; Disis, M.L.; Dranoff, G.; Gilboa, E.; Hammond, S.A.; Hershberg, R.; Korman, A.J.; et al. The Human Vaccines Project: A roadmap for cancer vaccine development. Sci. Transl. Med. 2016, 8, 334ps9. [CrossRef] [PubMed]

232. Stojadinovic, A.; Mittendorf, E.A.; Holmes, J.P.; Amin, A.; Hueman, M.T.; Ponniah, S.; Peoples, G.E. Quantification and Phenotypic Characterization of Circulating Tumor Cells for Monitoring Response to a Preventive HER2/neu Vaccine-Based Immunotherapy for Breast Cancer: A Pilot Study. Ann. Surg. Oncol. 2007, 14, 3359-3368. [CrossRef] [PubMed]

233. Birzele, F.; Voss, E.; Nopora, A.; Honold, K.; Heil, F.; Lohmann, S.; Verheul, H.; Le Tourneau, C.; Delord, J.P.; van Herpen, C.; et al. CD44 Isoform Status Predicts Response to Treatment with Anti-CD44 Antibody in Cancer Patients. Clin. Cancer Res. 2015, 21, 2753-2762. [CrossRef] [PubMed]

234. Maisel, D.; Birzele, F.; Voss, E.; Nopora, A.; Bader, S.; Friess, T.; Goller, B.; Laifenfeld, D.; Weigand, S.; Runza, V. Targeting Tumor Cells with Anti-CD44 Antibody Triggers Macrophage-Mediated Immune Modulatory Effects in a Cancer Xenograft Model. PLoS ONE 2016, 11, e0159716. [CrossRef] [PubMed]

235. Grugan, K.D.; McCabe, F.L.; Kinder, M.; Greenplate, A.R.; Harman, B.C.; Ekert, J.E.; van Rooijen, N.; Anderson, G.M.; Nemeth, J.A.; Strohl, W.R.; et al. Tumor-Associated Macrophages Promote Invasion while Retaining Fc-Dependent Anti-Tumor Function. J. Immunol. 2012, 189, 5457-5466. [CrossRef] [PubMed]

236. Chan, K.S.; Espinosa, I.; Chao, M.; Wong, D.; Ailles, L.; Diehn, M.; Gill, H.; Presti, J.; Chang, H.Y.; van de Rijn, M.; et al. Identification, molecular characterization, clinical prognosis, and therapeutic targeting of human bladder tumor-initiating cells. Proc. Natl. Acad. Sci. USA 2009, 106, 14016-14021. [CrossRef] [PubMed]

237. Braun, S.; Hepp, F.; Kentenich, C.R.; Janni, W.; Pantel, K.; Riethmuller, G.; Willgeroth, F.; Sommer, H.L. Monoclonal antibody therapy with edrecolomab in breast cancer patients: Monitoring of elimination of disseminated cytokeratin-positive tumor cells in bone marrow. Clin. Cancer Res. 1999, 5, 3999-4004. [PubMed] 
238. Schwartzberg, L.S. Clinical experience with edrecolomab: A monoclonal antibody therapy for colorectal carcinoma. Crit. Rev. Oncol. Hematol. 2001, 40, 17-24. [CrossRef]

239. Richter, C.E.; Cocco, E.; Bellone, S.; Silasi, D.-A.; Rüttinger, D.; Azodi, M.; Schwartz, P.E.; Rutherford, T.J.; Pecorelli, S.; Santin, A.D. High-grade, chemotherapy-resistant ovarian carcinomas overexpress epithelial cell adhesion molecule (EpCAM) and are highly sensitive to immunotherapy with MT201, a fully human monoclonal anti-EpCAM antibody. Am. J. Obstetr. Gynecol. 2010, 203, 582-e1. [CrossRef] [PubMed]

240. Seimetz, D.; Lindhofer, H.; Bokemeyer, C. Development and approval of the trifunctional antibody catumaxomab (anti-EpCAM $\times$ anti-CD3) as a targeted cancer immunotherapy. Cancer Treat. Rev. 2010, 36, 458-467. [CrossRef] [PubMed]

241. Zaloudik, J.; Li, W.; Jacob, L.; Kieny, M.P.; Somasundaram, R.; Acres, B.; Song, H.; Zhang, T.; Li, J.; Herlyn, D. Inhibition of tumor growth by recombinant vaccinia virus expressing GA733/CO17-1A/EpCAM/KSA/KS1-4 antigen in mice. Cancer Gene Ther. 2002, 9, 382-389. [CrossRef] [PubMed]

242. Chaudry, M.A.; Sales, K.; Ruf, P.; Lindhofer, H.; Winslet, M.C. EpCAM an immunotherapeutic target for gastrointestinal malignancy: Current experience and future challenges. Br. J. Cancer 2007, 96, 1013-1019. [CrossRef] [PubMed]

243. Mitchell, M.J.; Wayne, E.; Rana, K.; Schaffer, C.B.; King, M.R. TRAIL-coated leukocytes that kill cancer cells in the circulation. Proc. Natl. Acad. Sci. USA 2014, 111, 930-935. [CrossRef] [PubMed]

244. Mosolits, S.; Markovic, K.; Frodin, J.E.; Virving, L.; Magnusson, C.G.; Steinitz, M.; Fagerberg, J.; Mellstedt, H. Vaccination with Ep-CAM protein or anti-idiotypic antibody induces Th1-biased response against MHC class I- and II-restricted Ep-CAM epitopes in colorectal carcinoma patients. Clin. Cancer Res. 2004, 10, 5391-5402. [CrossRef] [PubMed]

245. Choi, Y.J.; Park, S.J.; Park, Y.S.; Park, H.S.; Yang, K.M.; Heo, K. EpCAM peptide-primed dendritic cell vaccination confers significant anti-tumor immunity in hepatocellular carcinoma cells. PLoS ONE 2018, 13, e0190638. [CrossRef] [PubMed]

246. Hamilton, D.H.; David, J.M.; Dominguez, C.; Palena, C. Development of Cancer Vaccines Targeting Brachyury, a Transcription Factor Associated with Tumor Epithelial-Mesenchymal Transition. Cells Tissues Organs 2017, 203, 128-138. [CrossRef] [PubMed]

247. Hackl, H.; Charoentong, P.; Finotello, F.; Trajanoski, Z. Computational genomics tools for dissecting tumour-immune cell interactions. Nat. Rev. Genet. 2016, 17, 441-458. [CrossRef] [PubMed]

248. Ting, D.T.; Wittner, B.S.; Ligorio, M.; Vincent Jordan, N.; Shah, A.M.; Miyamoto, D.T.; Aceto, N.; Bersani, F.; Brannigan, B.W.; Xega, K.; et al. Single-cell RNA sequencing identifies extracellular matrix gene expression by pancreatic circulating tumor cells. Cell Rep. 2014, 8, 1905-1918. [CrossRef] [PubMed]

249. Miyamoto, D.T.; Zheng, Y.; Wittner, B.S.; Lee, R.J.; Zhu, H.; Broderick, K.T.; Desai, R.; Fox, D.B.; Brannigan, B.W.; Trautwein, J.; et al. RNA-Seq of single prostate CTCs implicates noncanonical Wnt signaling in antiandrogen resistance. Science 2015, 349, 1351-1356. [CrossRef] [PubMed]

250. Andree, K.C.; Mentink, A.; Zeune, L.L.; Terstappen, L.; Stoecklein, N.H.; Neves, R.P.; Driemel, C.; Lampignano, R.; Yang, L.; Neubauer, H.; et al. Towards a real liquid biopsy in metastatic breast and prostate cancer: Diagnostic LeukApheresis increases CTC yields in a European prospective multi-center study (CTCTrap). Int. J. Cancer 2018. [CrossRef] [PubMed]

251. Tagawa, S.T.; Scherr, D.; Batra, J.; Jhanwar, Y.; Robinson, B.; Nanus, D.; Beltran, H.; Molina, A.; Christos, P.; Bander, N. Anti-prostate-specific membrane antigen (PSMA) monoclonal antibody (mAb) J591 immunotherapy for prostate cancer. Ann. Oncol. 2016, 27, 772TiP. [CrossRef]

252. Heery, C.R.; Palena, C.; McMahon, S.; Donahue, R.N.; Lepone, L.M.; Grenga, I.; Dirmeier, U.; Cordes, L.; Marte, J.; Dahut, W.; et al. Phase I Study of a Poxviral TRICOM-Based Vaccine Directed Against the Transcription Factor Brachyury. Clin. Cancer Res. 2017, 23, 6833-6845. [CrossRef] [PubMed]

253. Heery, C.R.; Donahue, R.; Lepone, L.; Grenga, I.; Richards, J.; Metenou, S.; Fernando, R.I.; Dirmeier, U.; Singh, H.; Madan, R.; et al. Phase I, dose-escalation, clinical trial of MVA-Brachyury-TRICOM vaccine demonstrating safety and brachyury-specific T cell responses. J. ImmunoTher. Cancer 2015, 3, P132. [CrossRef]

254. Bidard, F.; cottu, P.; Dubot, C.; Venat-Bouvet, L.; Lortholary, A.; Bourgeois, H.; Bollet, M.; Hanon, V.S.; Luporsi-Gely, E.; Espie, M.; et al. 117P-Anti-HER2 therapy efficacy in HER2-negative metastatic breast cancer with HER2-amplified circulating tumor cells: Results of the CirCe T-DM1 trial. Ann. Oncol. 2017, 28 (Suppl. 5), v22-v42. [CrossRef] 
255. Ignatiadis, M.; Rack, B.; Rothe, F.; Riethdorf, S.; Decraene, C.; Bonnefoi, H.; Dittrich, C.; Messina, C.; Beauvois, M.; Trapp, E.; et al. Liquid biopsy-based clinical research in early breast cancer: The EORTC 90091-10093 Treat CTC trial. Eur. J. Cancer 2016, 63, 97-104. [CrossRef] [PubMed]

256. Imhof, M.; Lipovac, M.; Angleitner-Boubenizek, L.; Barta, J.; Gomez, I.; Hrdina, A.; Krupa, E.; Lafleur, J.; Lang, I.; Pieta, K.; et al. Double-loaded mature dendritic cell (DC) therapy for non-HLA-restricted patients with advanced ovarian cancer: Final results of a clinical phase I study. J. Clin. Oncol. 2013, 31, 3052.

257. Van den Heuvel, M.M.; Verheij, M.; Boshuizen, R.; Belderbos, J.; Dingemans, A.M.; De Ruysscher, D.; Laurent, J.; Tighe, R.; Haanen, J.; Quaratino, S. NHS-IL2 combined with radiotherapy: Preclinical rationale and phase $\mathrm{Ib}$ trial results in metastatic non-small cell lung cancer following first-line chemotherapy. J. Transl. Med. 2015, 13, 32. [CrossRef] [PubMed]

258. Madan, R.A.; Bilusic, M.; Hodge, J.W.; Tsang, K.Y.; Arlen, P.M.; Heery, C.R.; Rauckhorst, M.; McMahon, S.; Intrivici, C.; Ferrara, T.A.; et al. A phase I trial of a yeast-based therapeutic cancer vaccine targeting CEA. J Clin. Oncol. 2011, 29, 2604. [CrossRef]

(C) 2018 by the authors. Licensee MDPI, Basel, Switzerland. This article is an open access article distributed under the terms and conditions of the Creative Commons Attribution (CC BY) license (http://creativecommons.org/licenses/by/4.0/). 